\title{
ESTUDO COMPARATIVO DAS ALTERAÇÕES CEFALOMÉTRICAS DO TRATAMENTO DA MÁ OCLUSÃO DE CLASSE II, SUBDIVISÃO, REALIZADO COM EXTRAÇÕES DE TRÊS PRÉ-MOLARES, COM O DE QUATRO PRÉ-MOLARES.
}

PAULO EDUARDO GUEDES CARVALHO

Tese apresentada à Faculdade de Odontologia de Bauru, da Universidade de São Paulo, como parte dos requisitos para obtenção do título de Doutor em Odontologia, área de Ortodontia.

(Edição Revisada) 


\section{ESTUDO COMPARATIVO DAS ALTERAÇÕES CEFALOMÉTRICAS DO TRATAMENTO DA MÁ OCLUSÃO DE CLASSE II, SUBDIVISÃO, REALIZADO COM EXTRAÇÕES DE TRÊS PRÉ-MOLARES, COM O DE QUATRO PRÉ-MOLARES.}

PAULO EDUARDO GUEDES CARVALHO

Tese apresentada à Faculdade de Odontologia de Bauru, da Universidade de São Paulo, como parte dos requisitos para obtenção do título de Doutor em Odontologia, área de Ortodontia.

(Edição Revisada)

Orientador:

Prof. Dr. Guilherme R. P. Janson 
Carvalho, Paulo Eduardo Guedes

C253e Estudo comparativo das alterações cefalométricas do tratamento da má oclusão de Classe II, subdivisão, realizado com extrações de três pré-molares, com o de quatro pré-molares./ Paulo Eduardo Guedes Carvalho Bauru, 2003.

143p. + apêndices: il.; 29,7cm.

Tese. (Doutorado) - Faculdade de Odontologia de Bauru, USP.

Orientador: Prof. Dr. Guilherme R. P. Janson.

Autorizo, exclusivamente para fins acadêmicos e científicos, a reprodução total ou parcial desta tese, por processos fotocopiadores e/ou meios eletrônicos.

Assinatura do autor:

Data:

Projeto de pesquisa aprovado pelo Comitê de Ética em Pesquisa da Faculdade de Odontologia de Bauru, Universidade de São Paulo, na reunião do dia 29 de março de 2001. 


\section{PAULO EDUARDO GUEDES CARVALHO}

06 de julho de 1974

São Paulo - SP

Nascimento

$1992-1996$

Curso de Odontologia na Faculdade de Odontologia de São Paulo, Universidade de São Paulo.

$1998-2000$

Curso de Pós-graduação em Ortodontia, ao nível de Mestrado, na Faculdade de Odontologia de Bauru, Universidade de São Paulo.

2001-2003

Curso de Pós-graduação em Ortodontia, nível de Doutorado, na Faculdade de Odontologia de Bauru, Universidade de São Paulo.

ASSOCIAÇÕES APCD - Associação Paulista dos Cirurgiões Dentistas - Central, São Paulo.

APEO - Associação Paulista de Especialistas em Ortodontia e Ortopedia Facial.

ABOR - Associação Brasileira de Ortodontia e Ortopedia Facial.

WFO - World Federation of Orthodontics 


\section{Dedicatória Especial}

À memória de meu avô, Daniel Guedes, exemplo de luta, determinação e sucesso. Representação maior do significado da vitória. 


\section{Dedicatória}

À minha esposa, Vanessa, pelo constante amor, carinho, companheirismo renovados a cada dia de nossa união $e$ pela compreensão nas horas em que estive ausente;

Aos meus queridos pais, Deocleciano e Maria Luiza, responsáveis pela formação do meu caráter, pelas orientações constantes, amor incondicional, apoio $e$ incentivo irrestritos;

Aos meus avós Azarias, Maria Antonietta e Maria Luiza pelo constante exemplo de amor e incentivo;

Dedico este trabalho. 


\section{Agradecimentos Especiais}

Aos meus sogros Sr. Luiz Carlos e Sra. Valéria, à minha cunhada Larissa e aos meus cunhados Carlos Augusto e Luiz Alexandre, pelo carinho e respeito com que me apoiaram durante toda esta jornada.

Ao meu tio, Daniel Guedes Júnior, pela torcida sempre presente; demonstrando seu carinho comigo não só nos momentos de alegria, mas também em todas as horas que necessitei de uma ajuda amiga.

Aos amigos Fabiano e Karine, pela sincera e preciosa amizade sempre presente.

A todos os meus familiares pelo carinho e estímulos sempre presentes.

A todos os meus amigos, que souberam entender os periodos que estive distante, mas nunca ausente do nosso convívio. 


\section{Agradecimento Especial}

Ao Prof. Dr. Guilherme Janson, meu orientador, não apenas pela orientação segura e paciente durante a elaboração deste trabalho, mas também pela confiança em mim depositada, oportunidade de convívio e enriquecimento do meu saber.

Minha sincera gratidão. 


\section{Agradecimentos}

Ao Prof. Dr. José Fernando Castanha Henriques, Professor Titular e Coordenador do Curso de Pós-Graduação em Ortodontia, nível de Doutorado, por honrar-nos com seus ensinamentos, como exemplo de pesquisador, professor e pela seriedade de seu trabalho.

Aos professores da disciplina de Ortodontia, Profs. Drs. Décio Rodrigues Martins, Renato Rodrigues de Almeida, Arnaldo Pinzan e Marcos Roberto de Freitas, pela experiência de vida transmitida durante toda minha formação profissional na Ortodontia.

Ao Prof. Dr. Luciano da Silva Carvalho, pelo carinho e incentivo constantes, além da amizade e oportunidade em compartilhar seus conhecimentos, contribuindo para o aprofundamento de minha qualificação pessoal $e$ profissional.

À Profa. Dra. Mirian Pattaro Carvalho, pela atenção e confiança em mim depositada e pelo incentivo durante todo o tempo.

Ao Dr. Luciano Guedes Pacces, primo, colega e sempre um grande amigo, que me acolheu com tanto carinho no meu retorno profissional à cidade de São Paulo. 
Ao Prof. Dr. Marcelo Gomes Garducci, pela amizade e atenção que sempre me dispensou.

Aos Profs. Drs. Eduardo Alvares Dainesi e Márcia Yuri Kawauchi, pela amizade e apoio demonstrados e sempre presentes.

Ao amigo Roberto Bom6onatti, sua esposa Juliana e filha Verena pela amizade sincera, companheirismo e incentivo durante toda minha vida na Ortodontia.

Aos amigos e sempre companheiros Danilo Furquim Siqueira e Danieli Colaço Siqueira, e suas sempre receptivas famílias, pelos momentos agradáveis compartilhados, ajuda sempre oferecida e por honrar-me com tão sincera $e$ calorosa amizade.

Aos amigos do Curso de Doutorado Adriano Lia Mondelli, Ana Carla Nahás, Ana Claúdia Conti, Daniela Gamba Garib-Carreira, Fausto Silva Bramente, Karina Santana Cruz, Karyna Valle Corotti e Renata Rodrigues de AlmeidaPedrin, e aos respectivos "agregados" pela amizade sempre presente em nosso convívio e por tudo que aprendemos.

Às funcionárias da Carvalho Ortodontia, Irismar, Marimar, Rosana e Virgínia, e ainda às colegas de profissão Márcia e Silvia pela ajuda doada em todos os momentos da realização deste trabalho. 
À Profa. Dra. Maria Fidela de Lima Navarro, Digníssima Diretora da Faculdade de Odontologia de Bauru, da Vniversidade de São Paulo.

Ao Prof. Dr. José Carlos Pereira, Presidente da Comissão de Pós-Graduaçào da Faculdade de Odontologia de Bauru, da Vniversidade de São Paulo.

Ao técnico de informática Daniel Francisco Rascão Selmo, pela auxílio constante e pelo tempo despendido na resolução dos problemas relacionados às minhas limitações na área da informática.

Aos funcionários da disciplina de Ortodontia, Luiz Sérgio Vieira, Maria José Santos Formenti, Teresa Cristina Alves Camaforte Ducatti e Vera Lúcia Rodrigues Purgato, por toda atenção e amizade durante o nosso convivio.

Aos funcionários da Pós-Graduação, pelas oportunidades e facilidades fornecidas.

Aos funcionários da Biblioteca, pela atenção e serviços prestados.

À Fundação de Amparo à Pesquisa do Estado de São Paulo (FAPESP), pelo auxílio à minha pesquisa, por meio da concessão da bolsa de estudos.

Agradeço a todos, à vida e a Deus por tudo o que tenho e por conceder-me a força de vencer obstáculos e atingir objetivos. 


\section{SUMÁRIO}

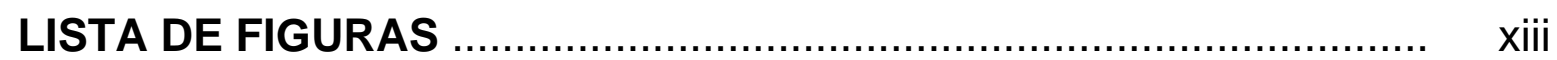

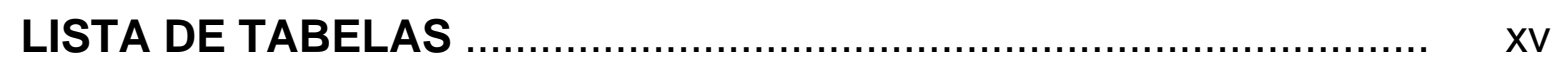

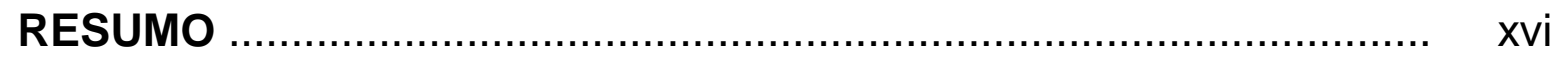

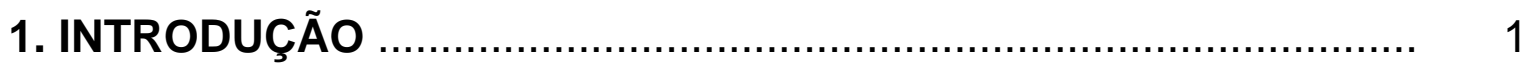

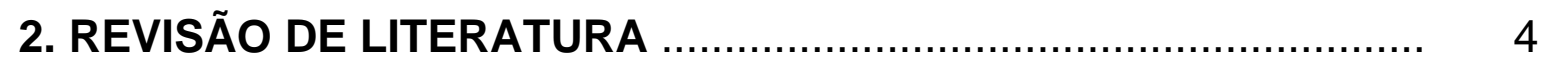

2.1 - A má oclusão de Classe II, subdivisão e as assimetrias ............ 5

2.2 - Tratamento da Classe II, subdivisão ............................... 22

2.3 - Extrações dentárias no tratamento da Classe II ..................... 40

2.4 - Estética facial e o perfil tegumentar ............................... 46

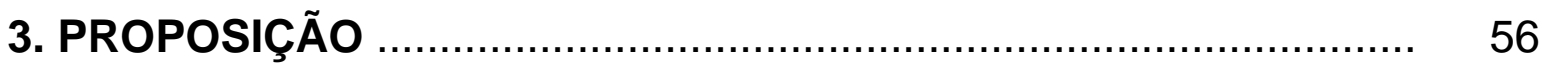

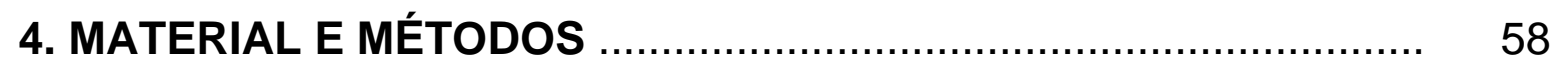

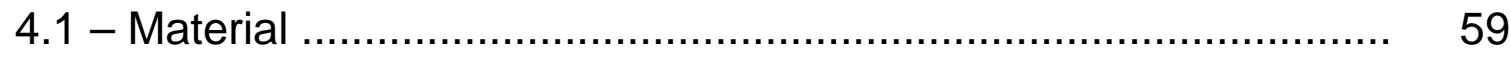

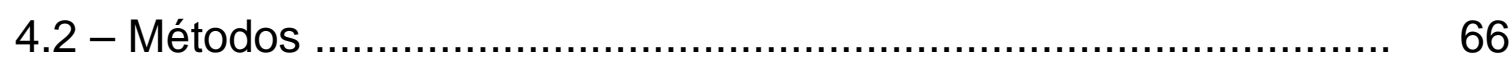

4.2.1 Obtenção das telerradiografias laterais .......................... 66

4.2.2 Traçado e medição das radiografias ............................. 67

4.2.3 Traçado anatômico .................................... 68

4.2.4 Pontos cefalométricos de referência ............................. 69

4.2.5 Linhas e planos de referência ........................................ 72

4.2.6 Medidas cefalométricas ...........................

4.2.7 Análise estatística ............................................... 79

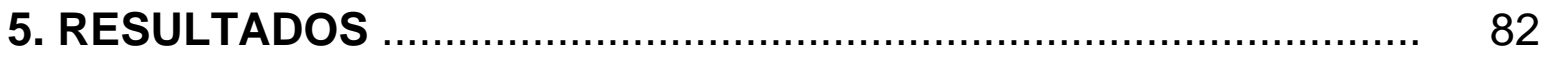




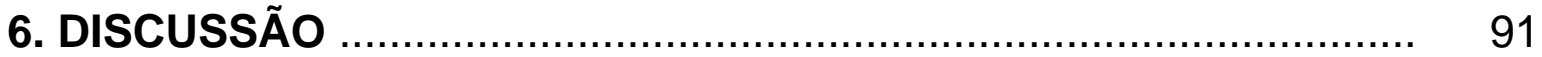

6.1 - Seleção da amostra .......................................................... 92

6.2 - Metodologia ….......................................................... 94

6.2.1 Magnificação das imagens radiográficas ............................. 95

6.2.2 Mensuração das grandezas cefalométricas ......................... 96

6.2.3 Medição dos índices de assimetrias .................................... 96

6.2.4 Precisão da metodologia ................................................... 98

6.3 - Discussão dos resultados .................................................. 100

6.3.1 Compatibilidade dos grupos ........................................... 100

6.3.2 Avaliação das alterações intergrupos .................................. 102

6.3.3 Implicações clínicas .......................................................... 117

6.4 - Sugestões de trabalhos futuros .......................................... 118

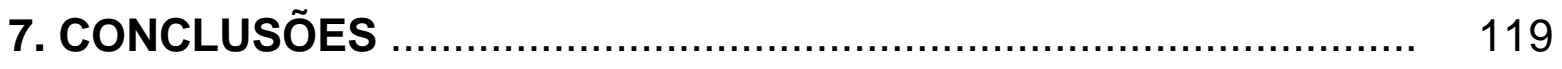

8. REFERÊNCIAS BIBLIOGRÁFICAS ….................................... 121

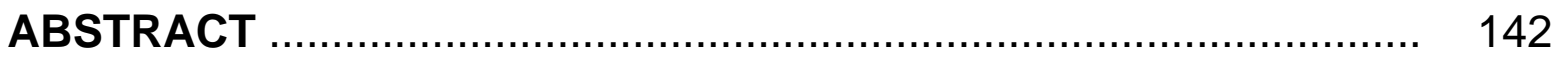
APÊNDICE 


\section{LISTA DE FIGURAS}

FIGURA 1 Modelos iniciais de caso de Classe II, subdivisão, tratado com extrações de três pré-molares

FIGURA 2 Modelos finais de caso de Classe II, subdivisão, tratado com extrações de três pré-molares

FIGURA 3 Modelos iniciais de caso de Classe II, subdivisão, tratado com extrações de quatro pré-molares

FIGURA 4 Modelos finais de caso de Classe II, subdivisão, tratado com extrações de quatro pré-molares

FIGURA 5

Grandezas

cefalométricas

esqueléticas

e tegumentares

75

FIGURA 6 Grandezas cefalométricas dentárias

77

FIGURA 7 Grandezas cefalométricas pertinentes aos índices de assimetria

FIGURA 8 Sobreposição em SN, centrado em S, dos traçados cefalométricos médios iniciais dos pacientes dos grupos 1 e 2

FIGURA 9 Sobreposição no Plano Palatino, centrado em ENA, dos traçados cefalométricos maxilares médios do grupo 1, nas fases inicial (T1) e final (T2) 
FIGURA 10 Sobreposição no Plano Palatino, centrado em ENA, dos traçados cefalométricos maxilares médios do grupo 2, nas fases inicial (T1) e final (T2)................. 108

FIGURA 11 Sobreposição no Plano Mandibular, centrado em Gn, dos traçados cefalométricos mandibulares médios finais dos pacientes dos grupos 1 e 2

FIGURA 12 Sobreposição no Plano Mandibular, centrado em Gn, dos traçados cefalométricos mandibulares médios do grupo 1, nas fases inicial (T1) e final (T2)

FIGURA 13 Sobreposição no Plano Mandibular, centrado em Gn, dos traçados cefalométricos mandibulares médios do grupo 2, nas fases inicial (T1) e final (T2)

FIGURA 14 Sobreposição em SN, centrado em S, dos traçados cefalométricos médios iniciais dos pacientes dos grupos 1 e 2

FIGURA 15 Sobreposição em SN, centrado em S, dos traçados cefalométricos médios do grupo 1 , nas fases inicial (T1) e final (T2)

FIGURA 16 Sobreposição em SN, centrado em S, dos traçados cefalométricos médios do grupo 2 , nas fases inicial (T1) e final (T2) 


\section{LISTA DE TABELAS}

TABELA 1 Médias das idades iniciais e finais dos pacientes nos dois grupos e suas diferenças

TABELA 2 Análise do erro intra-examinador. Apresentação dos erros casuais (Dahlberg) e sistemáticos 84

TABELA 3 Resultado do teste Kolmogorov-Smirnoff para os valores iniciais (T1), finais (T2) e alterações (T2-T1) para o grupo 1

TABELA 4 Resultado do teste Kolmogorov-Smirnoff para os valores iniciais (T1), finais (T2) e alterações (T2-T1) para o grupo 2

TABELA 5 Resultado do teste $t$ pareado entre as variáveis iniciais dos grupos 1 e 2 (compatibilidade da amostra) ..

TABELA 6 Resultado do teste $t$ independente entre as alterações ocorridas nos pacientes dos grupos 1 e 2 durante o tratamento 88

TABELA 7 Alterações ocorridas com o tratamento no grupo 1 .... 89 TABELA 8 Alterações ocorridas com o tratamento no grupo 2 .... 90 
RESUMO 


\section{RESUMO}

O objetivo deste trabalho foi comparar os resultados cefalométricos dentários, esqueléticos e tegumentares, de casos de Classe II, subdivisão, com características semelhantes, tratados sob dois protocolos distintos de extrações dentárias. A amostra consistiu de dois grupos, com 58 telerradiografias cada, iniciais (T1) e finais (T2), de 29 pacientes, apresentando as seguintes características: grupo 1 - jovens com Classe II, subdivisão, tratados com extrações assimétricas de três pré-molares, sendo dois superiores e um inferior do lado da relação de Classe I; grupo 2 - jovens também com Classe II, subdivisão, entretanto tratados com extrações simétricas de quatro pré-molares, dois superiores e dois inferiores. Todos apresentavam os dentes permanentes superiores e inferiores, até os primeiros molares, no início do tratamento. A média de idade inicial da amostra foi de 14,28 e 13,15 anos e a final de 16,90 e 15,64 anos nos grupos 1 e 2, respectivamente. As diferenças intragrupo ocorridas entre as fases (T1 $x$ T2) foram analisadas pelo teste $t$ dependente, enquanto a comparação intergrupos das alterações obtidas com os distintos tratamentos (T2-T1) foram verificadas com $o$ teste $t$ independente. Os resultados demonstraram a existência de diferença significante entre as alterações proporcionadas pelos dois tratamentos em relação: ao componente dentoalveolar ântero-inferior, onde a terapêutica realizada com três extrações propiciou menor retração dos incisivos inferiores; a uma menor retrusão do perfil tegumentar nos casos corrigidos com este protocolo de extrações, em relação ao grupo corrigido com extrações simétricas de quatro pré-molares; a um aumento do índice de assimetria dos molares inferiores no grupo tratado com extrações assimétricas, de modo oposto ao verificado no grupo com extrações simétricas de quatro pré-molares. 


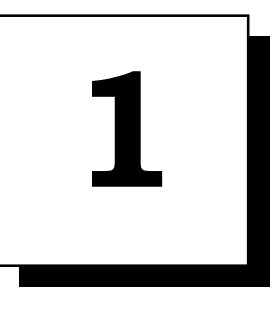

INTRODUÇÃO 


\section{INTRODUÇÃO}

Pacientes com má oclusão de Classe II, subdivisão apresentam características de Classe I de um dos lados, e de Classe II do lado oposto. Alguns estudos mostraram que esta má oclusão resulta principalmente de uma assimetria na posição dos molares inferiores, onde este se apresenta em uma posição mais posterior, no lado da Classe II, sendo o componente dentoalveolar o que mais contribui para a relação ântero-posterior assimétrica ${ }^{3,59,101}$. Uma diferença secundária consiste na posição mais mesial do primeiro molar superior no lado da Classe $1{ }^{59}$. Deste modo, verificou-se que em grande parte dos casos de Classe II, subdivisão, a linha média dentária superior apresenta-se coincidente, ou minimamente desviada, enquanto a linha média dentária inferior se apresenta deslocada para o lado da Classe $\|^{3,23,59,66,72,95,101}$, em uma face apresentando assimetria subclínica ${ }^{33,110}$. Dentre as más oclusões de Classe II, os casos de subdivisões representam cerca de $50 \%$ do número total de pacientes ${ }^{6,131}$. O relacionamento oclusal pertinente a uma má oclusão de Classe II, subdivisão, reflete um posicionamento assimétrico dos arcos dentários, acentuando a dificuldade de seu tratamento ortodôntico $0^{65,104,115-117,121}$.

Devido a estas características mais freqüentes da má oclusão de Classe II, subdivisão, uma das melhores opções de tratamento consiste na extração assimétrica de três pré-molares, sendo dois superiores e um inferior, no lado da Classe $\left.\right|^{3,19,24,31,32,34,58,59,62,127,138}$, desde que o perfil do paciente aceite certa retração dos incisivos superiores e inferiores. Uma outra possibilidade de correção pode ser realizada com a extração simétrica de quatro pré- 
molares, dois superiores e dois inferiores ${ }^{62}$. Apesar deste protocolo também permitir a obtenção de resultados satisfatórios, ele pode requerer uma maior utilização de elásticos intermaxilares de Classe II e anteriores, criando uma maior dependência da terapêutica na cooperação do paciente com 0 tratamento $31,32,42,59,62,68,74,96,98$.

Uma vez que a principal diferença entre os dois protocolos localize-se na realização de uma extração inferior a menos nos casos tratados com extrações assimétricas, parece lógico esperar que estes casos apresentem uma menor retração dos incisivos inferiores com o tratamento, em relação ao tratamento realizado com quatro extrações. Esta expectativa já foi expressa em alguns estudos ${ }^{34,58,59,62,61}$, entretanto sem que houvesse conclusão científica a este respeito. Conseqüentemente, considerando real esta diferença de retração dos incisivos inferiores entre os dois protocolos de extrações, especula-se também uma maior retração do perfil tegumentar nos casos tratados com quatro extrações ${ }^{17,34,59,62,90,140}$. Desta forma, a finalidade do presente trabalho é estudar o comportamento cefalométrico dos pacientes com Classe II, subdivisão, frente aos dois protocolos de extrações citados, com a finalidade de esclarecer estas especulações. 


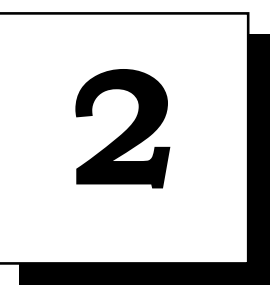

REVISÃO DE

LITERATURA 


\section{REVISÃO DE LITERATURA}

Nas más oclusões de Classe II, subdivisão, a presença de uma relação oclusal assimétrica torna o tratamento ortodôntico mais difícil, sendo diversas as propostas para correção desta má oclusão. Neste trabalho, duas possibilidades de tratamento da Classe II, subdivisão estão sendo comparadas cefalometricamente. Com a intenção de uma melhor interpretação dos resultados deste estudo e de suas principais conseqüências clínicas, este capítulo revisa a literatura pertinente a este tema, de acordo com a seqüência de tópicos a seguir:

2.1 - A má oclusão de Classe II, subdivisão e as assimetrias;

2.2 - Tratamento da Classe II, subdivisão;

2.3 - Extrações dentárias no tratamento da Classe II

2.4 - Estética facial e o perfil tegumentar

\section{1 - A má oclusão de Classe II, subdivisão e as assimetrias}

ANGLE ${ }^{6}$, baseando-se na relação dos primeiros molares permanentes, apresentou uma classificação das más oclusões, dividindo-as em Classe I, II ou III. A Classe II é caracterizada pela formação de um degrau distal na relação molar e pode ser originada esqueleticamente a partir de uma protrusão maxilar ou de uma retrusão mandibular ou ainda da combinação de ambas características. Muitas vezes, a relação entre as bases apicais pode 
apresentar-se normal e a Classe II resulta, então, da má posição dentária em suas bases ósseas, por uma posição mais mesial dos dentes superiores ou por uma posição mais distal dos dentes inferiores ou por uma combinação de ambos os fatores ${ }^{52,80,86,138}$. Sabe-se que $50 \%$ das más oclusões de Classe II constituem-se em subdivisões, merecendo uma atenção especial quanto à sua correção ${ }^{131}$.

CHENEY ${ }^{31}$, em 1952, observou que pode haver vários tipos e combinações de desenvolvimento assimétrico, alguns deles envolvendo as estruturas profundas das bases apicais, enquanto que outros ocorreriam nos arcos dentários. Ainda um outro grupo resultaria em diferenças em tamanho e forma dos arcos dentários opostos. Quando essas e outras assimetrias estiverem presentes, a natureza do problema torna-se bastante individual, permitindo ao autor concluir que não existe regras fixas ou padrões de tratamento para a correção dessas más oclusões. Em muitos indivíduos, um lado da face é diferente do outro e nesses casos é aconselhável planejar o tratamento para resolver os problemas dentoesqueléticos, de acordo com a necessidade individual. Não se deve presumir que todo plano de tratamento ortodôntico seja bilateral. Além das assimetrias intrínsecas das bases apicais, existem também as assimetrias entre as bases apicais e as desarmonias entre as formas dos arcos dentários.

Com o propósito de investigar a existência de uma diferença lateral sistemática entre os lados direito e esquerdo do arco superior, HUNTER ${ }^{55}$, em 1953, afirmou que a simetria maxilomandibular seria normal e sugeriu que a assimetria lateral associa-se à má formação de um dos arcos dentários. A amostra foi selecionada aleatoriamente seguindo alguns critérios: os arcos não deveriam apresentar mutilações, hipoplasia do esmalte, restaurações e erupção insuficiente. Para tanto, avaliou 93 modelos de jovens do sexo 
masculino com 13 anos de idade, utilizando projeções ortogonais paralelas ao plano oclusal dos arcos dentários. Para cada traçado, quatro medidas foram obtidas - as distâncias em milímetros da rafe mediana até o ponto da cúspide mesiolingual de cada primeiro molar e da rafe até a cúspide lingual dos primeiros pré-molares. Concluiu que nenhuma diferença sistemática pode ser demonstrada em ambos os lados.

De acordo também com CHENEY ${ }^{32}$, em 1961, quatro tipos de assimetrias dentofaciais poderiam requerer especial consideração no tratamento das más oclusões. Em primeiro lugar, os deslocamentos unilaterais ântero-posteriores, descritos como as diferenças horizontais ântero-posteriores de tamanho, forma e/ou posição das estruturas, nos lados direito e esquerdo da face, como em indivíduos nos quais o ângulo goníaco de um lado da face estaria mais para anterior do que o outro. Nessa assimetria, o estabelecimento de um diagnóstico correto poderia indicar a necessidade de um padrão de extrações assimétricas em uma má oclusão em que há um apinhamento mandibular significante e posições ântero-posteriores diferentes dos molares dos lados direito e esquerdo. Em segundo lugar, os deslocamentos verticais, definidos como diferenças em altura entre as estruturas dentofaciais dos dois lados da face, como em pacientes com maior altura do ramo mandibular de um lado. Os problemas clínicos associados a essa deformidade poderiam incluir uma diferença na altura dos olhos, nas proeminências malares e também na inclinação do plano oclusal. Uma tentativa de simplesmente corrigir os dentes, sem prestar atenção ao problema esquelético, poderia resultar numa recidiva desfavorável póstratamento, com restabelecimento parcial ou total da inclinação oclusal. Em terceiro lugar, deslocamentos laterais poderiam ocorrer em relação ao plano médio sagital, com variações horizontais no tamanho, forma e/ou posição das partes dentofaciais dos dois lados da face. Um deslocamento lateral poderia 
ocorrer na base mandibular (por exemplo, quando a ponta do mento estivesse deslocada para um lado e o ângulo goníaco mais deslocado lateralmente, em relação ao plano médio sagital do outro lado), ou poderia estar restrito ao processo dentoalveolar da própria base apical. No último exemplo, uma decisão deveria ser tomada se a correção ortodôntica da forma do arco fosse suficiente para corrigir o problema, senão seria necessária uma intervenção cirúrgica. Finalmente, os deslocamentos por rotação aparecem descritos como um deslocamento de todo o corpo da maxila ou de variações em tamanho de todo ramo. O tratamento desses deslocamentos assimétricos algumas vezes não permite o ajuste dos dentes ou arcos dentários em suas bases apicais. Sabendo-se da dificuldade em se corrigir os desequilíbrios entre a base apical e o arco dentário, deveria-se procurar, ao menos, evitar as cirurgias que apresentassem um prognóstico desfavorável. O ortodontista talvez precise aceitar em ajustar à base (para evitar o posicionamento dos dentes em locais sem suporte ósseo) e terminar o tratamento com algum desvio da linha média.

As várias assimetrias dentárias que podem existir na dentadura permanente foram estudadas em 1966 por GARN; LEWIS; KEREWSKY ${ }^{45}$, em 239 modelos de gesso, medindo-se os diâmetros mésio-distais das coroas dentárias. Eles encontraram que os valores para a assimetria foram maiores para os dentes superiores como um todo, em relação aos dentes inferiores; que dentes grandes, em geral, eram caracterizados por uma maior assimetria direita-esquerda; e que os valores de assimetria eram ligeiramente maiores em pacientes com agenesia de terceiro molar. Algumas vezes, as assimetrias dentárias resultariam em assimetrias funcionais, que poderiam ser tratadas com pequenos ajustes oclusais, ou com tratamento ortodôntico para os desvios mais acentuados. 
WERTZ ${ }^{138}$, em 1975, apresentou três casos de má oclusão de Classe II unilateral com etiologia e tratamento diferentes. Os casos de Classe II unilaterais são difíceis de serem tratados, pois podem apresentar uma etiologia multifatorial. A causa específica da assimetria deve ser identificada em cada paciente, porém o mais importante é diferenciar entre uma assimetria dentária e uma esquelética. Para as assimetrias dentárias, o segmento dos arcos dentários responsáveis pelo problema deve ser identificado para o correto planejamento do caso. Quando se verifica que a má oclusão é dentária, o autor advoga a utilização de um dispositivo para determinar em qual arco dentário está ocorrendo a alteração. Nestes casos, sugere a utilização de extrações assimétricas para a resolução da má oclusão. Afirmou também ser raro observar qualquer magnitude de desarmonia esquelética nos casos de Classe II unilateral, concluindo que os casos de más oclusões unilaterais de Classe II apresentam muitas causas diferentes e o plano de tratamento deve ser baseado no problema individual específico.

Alguns estudos demonstraram uma tendência para a maxila ser mais assimétrica que a mandíbula ou que as regiões dentoalveolares. VIG; HEWITTT $^{137}$, em 1975 e SHAH; JOSHI ${ }^{111}$, em 1978, demonstraram que na oclusão normal, a região dentoalveolar apresentaria menos assimetria do que as áreas esqueléticas da face e sugeriram que pode haver um mecanismo adaptativo que explique isto.

Utilizando radiografias submentonianas e póstero-anteriores, WILLIAMSON; SIMMONS ${ }^{141}$, em 1979, estudaram a assimetria mandibular relacionada à dor e à disfunção. Foram radiografados 53 pacientes com má oclusão pré-tratamento ortodôntico, sendo 27 do sexo feminino e 26 do sexo masculino, com idade média de 14,2 anos, com a mandíbula posicionada em 
relação cêntrica. As diferenças entre os lados direito e esquerdo da mandíbula foram mensuradas nas duas normas radiográficas. O relacionamento dentário foi observado nos modelos para ver se existia uma má oclusão de Classe II mais acentuada no lado mais curto da mandíbula. A quantidade de dor prétratamento durante a palpação muscular foi correlacionada com o grau de assimetria encontrada. Nenhuma correlação estatisticamente significante foi demonstrada entre a assimetria mandibular e a sensibilidade muscular. Os resultados demonstraram que a má oclusão de Classe II de molar e de canino pode ser mais difícil de ser corrigida de um lado do que do outro, caso não haja uma compensação da posição da fossa glenóide ou dos dentes superiores. Verificaram que a maioria dos casos da amostra apresentavam assimetria, devendo os clínicos estarem cientes da sua presença em todos os três planos de espaço quando se planeja previamente o tratamento.

Também em 1979, BURSTONE ${ }^{23}$ considerou que a assimetria ocorria mais freqüentemente que a simetria e que seu diagnóstico seria muito importante para o correto planejamento. Inúmeras discrepâncias de linha média seriam causadas por assimetrias que poderiam passar despercebidas, fato que acarretaria em problemas ao final do tratamento.

Em 1980, PROFFIT; VIG; TURVEY ${ }^{97}$ relataram a relação entre a fratura precoce dos côndilos mandibulares e as alterações de crescimento nesta estrutura óssea. Nos casos de pacientes pubescentes que sofrem uma fratura condilar encontra-se indicado a utilização de recursos ortopédicos que estimulem o crescimento mandibular e o desenvolvimento dos tecidos relacionados. Também é interessante se recorrer aos aparelhos funcionais híbridos que amenizam as deformidades faciais, ao promoverem um estímulo melhor direcionado ao lado afetado pela fratura. 
Há evidências de que a mandíbula possa contribuir para a assimetria, em más oclusões com subdivisões. ALAVI; BEGOLE; SCHNEIDER ${ }^{3}$, em 1988, desenvolveram um estudo com o objetivo de investigar a presença de diferenças significantes em relação às assimetrias faciais e dos arcos dentários, entre indivíduos que apresentavam más oclusões de Classe II, subdivisão, e aqueles com oclusão normal. Obteve-se medidas lineares das radiografias cefalométricas laterais, póstero-anteriores e dos modelos de estudo. Medidas específicas foram agrupadas para produzir vários índices de assimetria. As variáveis foram analisadas com uma análise discriminante multivariada. Verificaram que a assimetria ântero-posterior das más oclusões de Classe II, subdivisão, devia-se principalmente à posição mais distal do molar inferior, do lado da Classe II. Entretanto, não foi possível determinar se a posição do molar inferior devia-se a uma assimetria esquelética ou dentoalveolar. A assimetria da região dentoalveolar da maxila apresentou uma contribuição secundária.

Também em 1988, SLAVICEK ${ }^{121}$, afirmou que há uma grande quantidade de casos assimétricos e que seu diagnóstico apresenta suma importância. Quando se inicia precocemente um caso assimétrico esquelético, tem-se a oportunidade de conduzi-lo simetricamente. Quando se inicia o tratamento tardiamente, ou também, quando o paciente procura o ortodontista muito tarde, então deve-se estar consciente de que a terapêutica deve ser assimétrica. Algumas assimetrias podem ser vistas pelo exame radiográfico, quando os condutos auditivos não estão alinhados, ou quando se vê a diferença de altura do ramo e um plano oclusal oblíquo. Em alguns casos as assimetrias são verificadas em relação às diferenças entre os lados direito e esquerdo, na radiografia frontal. Finalmente, concluiu que é necessário estar ciente da presença da assimetria, especialmente a do movimento articular 
para se fazer um diagnóstico funcional de todos os casos assimétricos, especialmente os mais severos.

KANTOMAA $^{67}$, em 1989, afirmou que o contorno da eminência articular mostra grande variação individual, podendo relacionar-se com a morfologia da face. A morfologia mandibular correlaciona-se com a inclinação da superfície articular da fossa glenóide, de modo que uma mandíbula retangular decorre de uma fossa profunda, enquanto que uma mandíbula triangular provém de uma fossa rasa. Desta forma, concluiu-se que a morfologia da fossa glenóide constitui-se num elemento essencial do crescimento mandibular, havendo um íntimo relacionamento entre sua posição e algumas discrepâncias esqueléticas e as más oclusões. A fossa glenóide, nas más oclusões de Classe I, localiza-se mais anteriormente do que na Classe II, enquanto que na Classe III, relaciona-se mais anteriormente em relação ao crânio.

Utilizando-se de radiografias póstero-anteriores, PECK; PECK; KATAJA $^{92}$, em 1991, avaliaram a intensidade e a variabilidade morfológica da assimetria craniofacial subclínica. Estudaram uma amostra de telerradiografias frontais de 52 adultos leucodermas, apresentando bom equilíbrio facial, sendo 49 jovens do sexo feminino e três do sexo masculino, com idade média de 21 anos e dois meses. A determinação da assimetria esquelética foi realizada por meio de três medidas bilaterais esqueléticas que foram: órbita látero-superior, zigoma e gônio. A diferença entre os lados esquerdo e direito da hemiface foi quantificada em milímetros para que a largura total entre os pontos bilaterais fossem calculados. Os valores absolutos da diferença esquerda-direita foram utilizados para computar a média absoluta da assimetria entre cada uma das três dimensões estudadas. A órbita látero-superior demonstrou a menor assimetria e a menor variabilidade das três dimensões avaliadas, enquanto que a distância vertical 
entre o zigoma e o gônio revelou a mais forte diferença assimétrica na amostra. Já que estas duas últimas medidas relacionam-se com a oclusão dentária, concluíram que a posição dos dentes pode determinar um desenvolvimento significante da assimetria. Testes adicionais para determinar a dominância esquerda-direita dos dados também foram realizados. Os resultados revelaram que houve uma ligeira dominância para o lado direito, embora não tenha sido estatisticamente significante. Concluíram que o complexo craniofacial exibe uma menor assimetria e uma maior estabilidade dimensional à medida que se aproxima do crânio, validando o uso do ponto cefalométrico orbital látero-superior como ponto de referência craniano estável no cefalograma frontal.

A assimetria mandibular, em observações clínicas e radiográficas, resulta em um crescimento acelerado do côndilo mandibular de um lado ou o decréscimo do crescimento do lado oposto. TALLENTS et al. ${ }^{125}$, também em 1991, comentaram que a assimetria mandibular geralmente relaciona-se com uma hiperplasia condilar unilateral associada a um crescimento acelerado. Comentaram que as conseqüências das assimetrias mandibulares poderiam ser a mordida aberta, o desvio da linha média mandibular em direção contrária ao maior lado, a inclinação do plano oclusal e a mordida cruzada do lado mais curto. As alterações faciais mais comuns seriam o desvio do mento, em sentido contrário ao lado mais longo, ou proeminência ou achatamento da região goníaca. Verificaram que o ângulo goníaco geralmente se encontra mais agudo no lado mais comprido.

ÁGUILA; ÁGUILA² realizaram, em 1993, um importante estudo analisando, longitudinalmente dos 5 aos 12 anos de idade, as alterações dentoesqueléticas e tegumentares do crescimento craniofacial de 541 jovens cubanos, sendo 292 do sexo masculino e 249 do feminino, divididos em dois 
grupos europeus e negros, sem mutilações dos arcos dentários e sem histórico de tratamento ortodôntico. Como parâmetro para a determinação da faixa etária de cada grupo, estipulou-se a utilização das telerradiografias tomadas nas idades de 5, 6, 7, 8, 9 e 12 anos. Inúmeras mensurações foram realizadas, como as angulares S.N.A, S.N.B, A.N.B, S-N. Go-Gn, o eixo "Y" de crescimento, o ângulo facial e o de convexidade facial. Analisando-se o período estudado como um todo, pôde-se observar que o ângulo S.N.A manteve-se constante em negros e europeus. O ângulo S.N.B aumentou em ambos os grupos e o A.N.B diminuiu na mesma proporção. Houve uma diminuição significante do ângulo S-N. Go-Gn, principalmente no no grupo formado por europeus. O eixo "Y" de crescimento mostrou redução significante com a idade apenas no grupo de europeus.

MARTINS DE ARAÚJO; SCHIRMER; ALMEIDA ${ }^{79}$, em 1994, avaliaram as assimetrias esqueléticas e dentárias em indivíduos com oclusão normal, nas radiografias póstero-anteriores e em modelos de estudo. A amostra consistiu de vinte indivíduos, com oclusão normal e com idade média de 22,4 anos. Nove triângulos bilaterais foram demarcados nos traçados cefalométricos, para descrever o complexo craniodentofacial. Calculou-se a área de cada triângulo e a freqüência das assimetrias ântero-posterior e transversa, nos modelos. Os resultados não demonstraram diferenças estatisticamente significantes entre os dois lados, nas radiografias, embora as áreas não tenham se apresentado simétricas. Não houve dimorfismo sexual em relação ao tamanho das áreas dos triângulos dos lados direito e esquerdo. As linhas médias dentárias superior e inferior, a rafe palatina dos modelos e 0 plano sagital mediano nas radiografias se mostraram quase coincidentes.

Também em 1994, ROSE et al. ${ }^{101}$ compararam a simetria mandibular de 28 indivíduos que apresentavam más oclusões de Classe II, subdivisão, com 
30 indivíduos com más oclusões de Classe I. Utilizando-se as radiografias submentonianas, a simetria foi avaliada medindo-se a diferença espacial relativa de pontos mandibulares nas dimensões ântero-posterior e transversal, determinadas por sistemas de coordenadas que representavam a base craniana, a mandíbula e os dentes inferiores. Somente aquelas variáveis que representavam a diferença ântero-posterior entre as posições dos molares inferiores direito e esquerdo demonstraram diferença estatisticamente significante entre os grupos. O primeiro molar inferior, quando avaliado relativamente à base craniana ou à própria mandíbula, estava localizado mais posteriormente no lado da Classe II, nas más oclusões com subdivisão, em uma mandíbula que não exibia nenhuma assimetria. Concluíram que um número significante de más oclusões de Classe II, subdivisão, é devido às assimetrias dentárias.

SEVERT; PROFFIT ${ }^{110}$, em 1997, avaliaram a prevalência de assimetria facial em uma população com deformidades dentofaciais na Universidade da Carolina do Norte. Avaliando 1.460 pacientes, detectaram que a assimetria facial clinicamente aparente estava presente em 495 pacientes, totalizando 34\% da amostra. Quando presente, a assimetria facial afetava a porção superior da face em apenas 23 casos (5\%), o terço médio, primeiramente 0 nariz, em 178 casos (36\%) e o mento em 365 casos (74\%). O plano oclusal apresentava-se inclinado, indicando uma assimetria vertical, em 201 casos (41\%). Os pacientes com Classe II, devido ou não à deficiência mandibular, apresentaram 28\% de prevalência de assimetria, enquanto os de más oclusões de Classe III e Classe I apresentaram 40\% de prevalência, tornandose significantemente mais elevado do que aqueles com más oclusões de Classe II. Quando o mento se apresentava desviado transversalmente, houve $80 \%$ de chance que este desvio fosse para o lado esquerdo. Somente nos pacientes com face longa, houve um deslocamento igual do mento tanto para 
a esquerda como para a direita. Nos outros grupos, a prevalência do desvio do mento para o lado esquerdo alcançou 90\%. Concluíram que estes resultados são significantes para os clínicos porque a assimetria pode ser identificada e planejada antes do inicio do tratamento.

Em 1998, JANSON ${ }^{57}$ realizou um trabalho com o objetivo de investigar a presença de diferenças dentárias e/ou esqueléticas entre indivíduos com más oclusões de Classe II, subdivisão, e aqueles com oclusão normal. A amostra consistiu de 30 indivíduos em cada um dos grupos. Todos apresentavam os dentes permanentes até os primeiros molares. A idade média dos indivíduos era de 15,76 e 22,42 anos no grupo com Classe II, subdivisão, e no grupo com oclusão normal, respectivamente. As medidas foram realizadas nas radiografias submentonianas, oblíquas e póstero-anteriores. Na radiografia submentoniana, a assimetria foi avaliada medindo-se a diferença relativa na posição espacial de pontos dentários e esqueléticos nas dimensões ânteroposteriores e transversais, determinadas por sistemas de coordenadas representando a mandíbula, o assoalho craniano, a maxila e os dentes inferiores e superiores. As variáveis foram analisadas com o teste t e com a análise de regressão logística de multivariáveis. Os resultados demonstraram que a principal diferença entre a má oclusão de Classe II, subdivisão, e a oclusão normal consiste em um posicionamento mais para distal do primeiro molar inferior do lado da Classe II, em uma mandíbula com assimetria normal e sem assimetria de posição. Uma diferença secundária entre os dois grupos consiste no posicionamento mais para mesial do primeiro molar superior, no lado da Classe II. Como conseqüência do posicionamento mais para distal, dos molares inferiores, do lado da Classe II, mais freqüente que o posicionamento dos molares superiores, para mesial, deste lado, a linha média dentária inferior também apresenta um desvio mais freqüente para o lado da Classe II, do que a linha média dentária superior, no sentido oposto, 
conforme evidenciado na avaliação bidimensional da radiografia PA. Cefalometricamente, os arcos dentários dos casos de má oclusão de Classe II, subdivisão, apresentam uma maior assimetria do que os de oclusão normal.

Também em 1998, LEGAN ${ }^{72}$ comentou que a mandíbula exerce uma contribuição dominante para a assimetria dentofacial já que forma o suporte esquelético dos tecidos moles da face inferior. De modo contrário, a maxila contribui com um suporte tegumentar mínimo, apresentando pequena participação na assimetria. Afirmou também que a maioria das assimetrias maxilares mostra-se secundária ao crescimento mandibular assimétrico, podendo ser mensurada simplesmente pela localização da linha média dentária superior e pela inclinação frontal do plano oclusal.

MARTINS et al. ${ }^{78}$ realizaram, no mesmo ano de 1998 , um importante estudo para a comunidade clínica e científica ortodôntica brasileira, analisando, longitudinalmente dos 6 aos 18 anos de idade, as alterações dentoesqueléticas e tegumentares do crescimento craniofacial de 75 jovens brasileiros, sendo 37 do sexo masculino e 38 do feminino, leucodermas, sem mutilações dos arcos dentários e sem histórico de tratamento ortodôntico. Como parâmetro para a determinação da faixa etária de cada grupo, estipulou-se a utilização das telerradiografias tomadas entre o período de 6 meses antes a 5 meses após a data de aniversário de cada jovem. Inúmeras mensurações angulares e lineares foram realizadas, como as angulares S.N.A, S.N.B, A.N.B, S-N. Go-Gn, o eixo "Y" de crescimento, o ângulo facial e o de convexidade facial e as lineares Co-A, Co-Gn, AFAI, AFAS e AFAT. Analisando-se o período estudado como um todo, pôde-se observar que 0 ânguto S.N.A manteve-se constante em ambos os sexos. O ângulo S.N.B aumentou em ambos os sexos e o A.N.B diminuiu na mesma proporção. 
Houve uma diminuição significante do ângulo S-N. Go-Gn, principalmente no sexo masculino, porém sem a presença de dimorfismo sexual. O eixo "Y" de crescimento mostrou-se praticamente constante. O ângulo facial exibiu um pequeno aumento em ambos os sexos. $O$ ângulo de convexidade facial diminuiu acentuadamente em ambos os sexos. A medida linear CO-A evidenciou um aumento em ambos os sexos. A variável CO-Gn também denotou um aumento significante em ambos os sexos. Em relação às alterações verticais anteriores pôde-se observar que a AFAl aumentou consideravelmente em ambos os sexos, sendo maior no sexo masculino.

Ainda em 1998, SHEATS et al. ${ }^{113}$ fizeram uma estimativa da magnitude de prevalência da assimetria dentária e facial em jovens americanos, sem história de tratamento ortodôntico prévio e compararam com os dados estatísticos de um grupo submetido ao tratamento ortodôntico. A amostra de pacientes sem tratamento foi selecionada numa escola pública da Flórida, sendo composta de dois grupos de jovens: o primeiro era constituído de 5.817 jovens, com média de idade de 9,3 anos e o segundo, de 861 adolescentes com 14,4 anos. A assimetria sagital do molar era encontrada em $30 \%$ dos jovens do primeiro grupo e em $23 \%$ dos jovens do segundo grupo. Uma avaliação adicional da assimetria no segundo grupo mostrou $12 \%$ de assimetria facial e $21 \%$ de não coincidência das linhas médias dentárias. No grupo de pacientes em tratamento, verificaram que a assimetria mais comum era o desvio da linha média inferior em relação à linha média facial, ocorrendo em $62 \%$ dos pacientes. Outras assimetrias ocorreram em ordem decrescente: falta de coincidência das linhas médias dentárias (46\%); desvio da linha média maxilar em relação à linha média facial (39\%); má oclusão assimétrica (22\%); assimetria oclusal maxilar (20\%); assimetria oclusal mandibular (18\%); assimetria facial (6\%); desvio do mento (4\%) e desvio nasal (3\%). Concluíram que não há associações significantes entre a assimetria facial e a não 
coincidência das linhas médias. Entretanto, associações estatisticamente significantes foram encontradas em relação à assimetria do molar e a assimetria facial, a assimetria do molar e a não coincidência das linhas médias e a assimetria do molar e o tipo racial. Os resultados desta pesquisa devem ser considerados com restrições devido à deficiente metodologia para a avaliação da assimetria. Os autores comentaram que os examinadores não foram adequadamente calibrados e ainda, os pacientes avaliados não foram analisados quanto à presença de desvios da relação cêntrica para a oclusão cêntrica e nem mesmo, com relação à coincidência das linhas médias.

JOHNSTON; BURDEN; STEVENSON ${ }^{66}$, em 1999, investigaram a percepção das discrepâncias entre as linhas médias dentária e facial, por meio de uma análise visual realizada por 20 ortodontistas e 20 leigos jovens. Utilizaram uma imagem fotográfica do sorriso de uma jovem, com a mesma expressão facial, modificando-se a linha média dentária em relação à linha média facial. Assim, pôde-se julgar o grau de atratividade do sorriso desta imagem, utilizando-se notas com escala de escores de dez pontos. Como resultados, verificaram que as imagens menos atraentes tanto para os ortodontistas como para os leigos relacionaram-se com o aumento da discrepância entre as linhas médias dentária e a facial. Os escores não avaliaram se a direção do desvio da linha média era para o lado direito ou esquerdo, e nem mesmo, referiu-se ao gênero do examinador. Concluíram que os ortodontistas eram mais sensíveis que as pessoas comuns no que concerne às discrepâncias menores entre as linhas médias dentária e facial. Além disso, calcularam que a probabilidade dos leigos considerarem um menor escore de atratividade era de $56 \%$, enquanto que para os ortodontistas era de $83 \%$, quando havia uma diferença de $2 \mathrm{~mm}$ entre as linhas médias dentária e a facial. Denotou-se que mesmo nos casos de discrepância mínima, havia um efeito negativo na estética dentofacial. Assim, afirmaram 
que todo tratamento ortodôntico deve incluir a correção completa das discrepâncias das linhas médias dentárias superior e inferior, tolerando-se para os casos mais severos, até no máximo $2 \mathrm{~mm}$ de discrepância entre estas linhas.

Com o objetivo de avaliar, numa amostra longitudinal de 90 pacientes, o desenvolvimento da linha média durante três períodos distintos de desenvolvimento, DI NICOLÓ et al. ${ }^{37}$, em 2000, realizaram um estudo com 180 pares de modelos de cada período da dentição (decídua, mista, permanente), classificando a linha média em coincidente e não coincidente. Os resultados revelaram que os desvios da linha média estavam presentes em $20 \%$ dos casos durante a dentição decídua, 27,8\% no período da dentição mista e $46,7 \%$ durante a dentição permanente. Concluíram que a presença de desvios da linha média pode ser diagnosticada durante estágios precoces de desenvolvimento da dentição e que a possibilidade de autocorreção é improvável.

JANSON et al. ${ }^{59}$, no ano de 2001, publicaram uma avaliação tridimensional para verificar a existência de diferenças significantes quanto às assimetrias dentárias e esqueléticas entre pacientes com má oclusão de Classe II, subdivisão e com oclusão normal. Após a avaliação dos dois grupos, compostos de 30 indivíduos cada, com o uso de radiografias pósteroanteriores, submentovértex e oblíqua corrigida, verificaram que o fator que mais colabora com a assimetria nos pacientes do grupo de Classe II subdivisão consiste na posição mais posterior do $1^{\circ}$ molar inferior, em pacientes que não apresentam assimetrias mandibulares esqueléticas. $O$ segundo principal fator é representado pela posição mais mesial do molar superior. Entretanto como a incidência de alteração no molar inferior é mais 
comum, verificou-se uma maior ocorrência de desvio da linha média inferior para o lado da Classe II.

PROCACl; RAMALHO ${ }^{95}$, em 2002, apresentaram uma revisão sobre o crescimento assimétrico da face e sua relação com aspectos oclusais e participação da atividade muscular. Observaram que as assimetrias congênitas e/ou genéticas devem ser corretamente diagnosticadas o mais precocemente possível, evitando-se planos de tratamento ineficientes. Verificaram que a atividade muscular pode modular a diferenciação tecidual e o crescimento, onde, juntamente com a constituição embriológica, podem contribuir para diversas alterações morfológicas. Relataram que a má oclusão de Classe II, subdivisão, relaciona-se com o crescimento assimétrico da face, ocorrendo normalmente junto ao desvio de linha média.

SIEGEL ${ }^{117}$, também em 2002, avaliou a interpretação da comunidade ortodôntica americana quanto ao significado da subdivisão no sistema de classificação de Angle. Após enviar 57 questionários a professores titulares de Ortodontia, recebeu 34 respostas. 22 questionários afirmavam que a subdivisão refere-se ao lado em relação de Classe II, 8 responderam que o termo está relacionado ao lado em Classe I, 3 respostas não relacionavam a subdivisão a qualquer dos lados específicos e o último indicava que entre os profissionais de sua equipe não havia consenso quando ao lado que se referia o termo da subdivisão. Apesar de prevalecer a visão que o termo subdivisão refere-se ao lado onde existe a relação molar alterada, mostra-se evidente que a comunidade ortodôntica americana não apresenta um padrão de unidade quanto a interpretação do significado da subdivisão. 


\subsection{Tratamento da má oclusão de Classe II, subdivisão}

Quando a má oclusão assimétrica apresenta-se associada a uma assimetria facial, a intensidade desta assimetria determina o tipo de tratamento a ser realizado. Se o grau de assimetria for acentuado e a queixa principal do paciente for esta, o tratamento deverá ser cirúrgico e se a assimetria facial for discreta e não constituir a queixa principal, o tratamento será restrito à correção dos problemas da má oclusão dentária ${ }^{14,143}$.

Na maioria dos casos de Classe II, subdivisão, a linha média dentária superior apresenta-se coincidente ou com um mínimo desvio em relação ao plano sagital mediano, enquanto que a linha média inferior geralmente apresenta-se deslocada para o lado da má oclusão. Nestes casos, uma das melhores opções de tratamento para a resolução desta má oclusão, consiste na extração de dois pré-molares superiores e um pré-molar inferior do lado da relação molar normal, desde que o perfil do paciente permita alguma retração dos incisivos superiores e inferiores ${ }^{3,31,32,34,58,59,127,138}$. Isto produzirá do lado da relação molar normal uma oclusão final com relações molar e de canino normais. Do lado da Classe II, produzirá uma oclusão final com uma relação molar de Classe II e uma relação de caninos normal e com as linhas médias dentárias superior e inferior coincidentes entre si e com o plano sagital mediano. A correção do desvio da linha média, nesta forma de tratamento, torna-se facilitada, uma vez que será obtida concomitantemente com o fechamento do espaço da extração do arco inferior. Há também uma necessidade mínima da utilização de elásticos intermaxilares para a correção da linha média, diferentemente do protocolo com extrações simétricas que necessita da utilização demasiada deste tipo de elástico $0^{50,59,74}$. Entretanto, há autores $^{24,41,96}$ que consideram que o tratamento com extrações assimétricas 
possa causar, também, efeitos dentoalveolares indesejáveis, principalmente no plano frontal.

Outra opção de tratamento, nesses casos, consiste em extrair mais um pré-molar inferior, do lado da Classe $\|^{31,32,138}$, para obter também uma relação de Classe I dos molares desse lado. Apesar deste segundo esquema de extrações também produzir resultados satisfatórios, ele pode requerer uma maior utilização de elásticos intermaxilares para ajudar na obtenção de uma relação de Classe I, de molar, deste lado. A correção do desvio da linha média também é dificultada, uma vez que para o fechamento do espaço da extração do pré-molar do lado da Classe II, a linha média tenderá a se deslocar ainda mais para esse lado. Isto cria uma dependência maior da colaboração do paciente e, portanto, é mais arriscado.

As mesmas características poderão estar presentes em pacientes com assimetria subclínica ${ }^{15,33}$, cujo perfil não permita esse esquema de extrações e uma certa quantidade de retração conseqüente. Nesse caso, o tratamento basicamente consistirá em se obter a correção ântero-posterior do lado da Classe II, com a utilização de elásticos de Classe II unilaterais, ou com o sistema de GIANELLY; PAUL ${ }^{46}$, utilizando-se elásticos de Classe II e elásticos diagonais anteriores. Em todo caso, tudo dependerá enormemente da colaboração do paciente. Esse tipo de mecânica unilateral é muito difícil de ser realizada e pode afetar o arco superior concomitantemente ${ }^{101}$, além de causar também inclinações indesejáveis do plano oclusa ${ }^{24,50,100}$. Por isso, ROSE et al. ${ }^{101}$ aconselham que, na ausência de uma assimetria ânteroposterior no arco superior, se houver apinhamento mínimo ou ausência deste nos arcos, deve-se pensar seriamente em aceitar a assimetria da oclusão, inclusive um desvio da linha média inferior e tratar o caso objetivando 
estabelecer trespasses anteriores horizontal e vertical corretos, como metas principais.

BUCHIN ${ }^{21}$, em 1967, não considerou as discrepâncias de linha média um grande problema e afirmou que as mesmas não são difíceis de serem corrigidas. A correção é difícil de ser mantida se a discrepância for causada por uma assimetria esquelética porém, se o diagnóstico estiver correto e ela não for causada por desarmonia esquelética, a sua correção é fácil, com a utilização de três elásticos: um elástico de Classe II de um lado, um de Classe III do outro e um elástico cruzado anterior. Todos eles são paralelos um ao outro, sendo que o terceiro elástico, ou anterior, é provavelmente o mais importante, mas todos devem ser utilizados. Se a discrepância de linha média for um artefato do tratamento, ela é facilmente corrigida dessa forma e se for causada por rotação mandibular, também o será, da mesma maneira. No tratamento de um caso de subdivisão, afirmou o autor que, com colocação dos aparelhos, ele passa de uma Classe II, subdivisão, para um caso de 1/2 Classe II, após o nivelamento e remoção das interferências cuspídicas. Em caso de Classe II, subdivisão, a linha média inferior geralmente está desviada para o lado da relação molar de Classe II. Em seguida ao nivelamento, alinhamento e utilização da mecânica de Classe II, geralmente se obtém uma relação de 1/3 Classe II do lado que originalmente era Classe II e uma ligeira relação de Classe III do lado originalmente Classe 1. Evidentemente nesse estágio a linha média inferior está desviada para o lado de 1/2 Classe II. Utiliza-se um elástico de Classe II deste lado, um de Classe III do lado oposto e um elástico paralelo no segmento anterior. A correção usualmente é obtida dentro de oito a dez semanas, com uma ligeira sobrecorreção. Essa mecânica também posiciona os caninos em relação de Classe I. 
A presença de uma linha média desviada ocorre principalmente nos casos de Classe II, devido a alguns fatores como o deslocamento mandibular resultante de uma mordida cruzada posterior, inclinação ou mesialização dos dentes, deslocamento mandibular sem mordida cruzada (rotação mandibular resultante de interferências oclusais), assimetrias dos arcos dentários, discrepâncias de tamanho dentário, ou uma combinação dos fatores acima. LEWIS $^{74}$, em 1976, apresentou uma série de perguntas necessárias para o diagnóstico diferencial das discrepâncias da linha média: 1- O que causou o desvio da linha média? 2- Como o desvio afeta a oclusão? 3- É necessário corrigi-lo? Teceu ainda as considerações seguintes: a correção de um desvio da linha média, causado por ligeiro deslocamento da mandíbula, quando não existe mordida cruzada, é geralmente mais fácil durante os estágios finais do tratamento; a linha média não constitui o problema mais importante, pois a preocupação principal é a correção da má oclusão, na região posterior, que está associada ao desvio da linha média; quando o lado da má oclusão for corrigido, a linha média geralmente estará corrigida, visto que o desvio é apenas uma indicação de que a oclusão não está bilateralmente correta. Em casos de deslocamento lateral da mandíbula, têm-se sugerido a utilização de elásticos de Classe III, do lado em que o relacionamento ântero-posterior estiver correto, concomitantemente com elásticos de Classe II, do lado oposto e elásticos cruzados anteriores para ajudar a correção da linha média. Isso tudo, no entanto, não é necessário porque os elásticos de Classe III podem prejudicar a oclusão do lado bem relacionado. Os elementos mais importantes nesse sistema são a tração anterior exercida pelos elásticos do lado da Classe II e a força lateral do elástico anterior, agindo ao mesmo tempo para corrigir a posição mandibular e dentária para o centro da face. Os elásticos de Classe II, ou elásticos anteriores, usados separadamente, não conseguem obter essa correção tão eficientemente como quando são utilizados simultaneamente. Quando indicada, a remoção de dentes de um ou de ambos 
os arcos conseguirá resolver alguns dos problemas de desvio de linha média, mas somente a extração não soluciona o problema completamente.

A correção das assimetrias dentárias com extrações simétricas de quatro pré-molares pode necessitar da utilização demasiada de elásticos de Classe II, de um lado, elástico de Classe III do outro e um elástico cruzado anterior, que podem causar inclinações indesejáveis do plano oclusal, pela vista frontal e o elástico de Classe III pode prejudicar a oclusão do lado bem relacionado. Além disto, a utilização demasiada destes elásticos podem causar um tracionamento do côndilo para a frente da posição de relação cêntrica, do lado da Classe II. A linha média até poderá ser corrigida, entretanto um côndilo não mais ficará em relação cêntrica. Se não ocorrer nenhum crescimento compensatório deste côndilo, que parece ser o que geralmente acontece clinicamente, haverá um desvio da oclusão de relação cêntrica para a máxima intercuspidação. Portanto, quando a linha média for avaliada, com ambos os côndilos assentados, apresentará um desvio. Se o desvio da linha média for devido a uma discrepância do tamanho dentário, o plano de tratamento deverá envolver extrações assimétricas, em casos de extrações, ou a aceitação do problema, em casos sem extrações, além da realização de ajuste oclusal após o tratamento ${ }^{19,65,74,140}$. É preciso acrescentar que essas considerações referem-se a uma finalização do tratamento dentro dos objetivos funcionais ortodônticos, que requerem que a mandíbula se apresente em relação cêntrica no final do tratamento ${ }^{63,103,140}$. Se o caso apresentar assimetria mandibular discreta e admitir extrações assimétricas, a linha média dentária poderá ser corrigida mais facilmente, mas a assimetria mandibular permanecerá:65,74.

WILLIAMSON ${ }^{140}$, em 1981 , comentou que a assimetria ocorre freqüentemente devido a fatores genéticos, funcionais e traumáticos. Quando 
uma assimetria existe, ocorre uma maior severidade da má oclusão de Classe II apenas de um lado, ocasionando uma Classe II, subdivisão. Afirmou também que quando o ortodontista trata em relação cêntrica, o plano de tratamento dos casos deve utilizar ancoragem máxima no arco superior, do lado deficiente. Em alguns casos severos, pode se chegar a uma relação de topo a topo, no lado mais curto da mandíbula, ao final do tratamento, considerando-se um sucesso. Quando se manipula a mandíbula em relação cêntrica, os dentes inferiores posicionam-se mais distalmente, comparando-se com os superiores, causando uma discrepância de linha média, com desvio mandibular para o lado deficiente, quando o côndilo se assenta. Como exemplo clínico, este autor citou um caso em que os elásticos assimétricos foram utilizados, não corrigindo a linha média. Relatou que, de um modo geral, $32 \%$ dos pacientes apresentam $3 \mathrm{~mm}$ ou mais de assimetrias mandibulares que podem ser verificadas em radiografias póstero-anterior e submentoniana ${ }^{141}$. Três milímetros equipara-se aproximadamente à largura de uma cúspide, levando uma Classe I, em máxima intercuspidação, para uma Classe II, em relação cêntrica. As assimetrias aparentemente podem ocorrer por deficiência do corpo mandibular de um lado, visualizadas pela radiografia submentoniana, ou pela deficiência de crescimento vertical, quando evidenciadas pela radiografia póstero-anterior. Em ambos os casos, o relacionamento de molar e de canino é mais Classe II, no lado deficiente, quando verificado em modelos de gesso articulados. Uma discrepância de linha média pode ser uma indicação de uma assimetria, sugerindo que um lado da oclusão pode ser mais Classe II que o outro. Se uma assimetria está presente e o caso está sendo tratado com o conceito de posição assentada no côndilo, o profissional deve terminar o caso com um lado mais Classe II que 0 outro. WILLIAMSON ${ }^{140}$ comentou que as forças dos elásticos intermaxilares podem empurrar o côndilo para frente e para fora da posição de repouso, no lado da Classe II, havendo a correção da discrepância de linha 
média, mas um côndilo não fica totalmente assentado. Se nenhum crescimento compensatório ocorre, a discrepância de linha média pode ser corrigida, porém um côndilo não fica assentado, havendo a produção de uma deflexão da oclusão de relação cêntrica até a máxima intercuspidação. Concluiu que nos problemas de linha média devido às discrepâncias de tamanho dentário, o plano de tratamento pode envolver extrações assimétricas, quando o caso permitir, ou aceitação do problema, em casos sem extração, com indicação de ajuste oclusal, ao final do tratamento.

SARNAS et al. ${ }^{105}$, em 1982, analisaram os efeitos do tratamento com o aparelho de Herbst, no crescimento facial de um paciente com microssomia hemifacial, em termos de deslocamento da mandíbula e dos ossos maxilares, em relação ao osso frontal. As medidas foram realizadas com precisão de 0,1 grau e 0,05mm. Antes do tratamento, as bases apicais estavam deslocadas para posterior e para o lado afetado pelo crescimento, aumentando o grau de retrognatia e de assimetria facial. Durante o tratamento, o crescimento facial foi redirecionado e as bases apicais, deslocadas para anterior e para o lado não afetado, diminuindo o grau de retrognatia e assimetria. Entretanto, ao mesmo tempo, a inclinação da mandíbula para o lado afetado aumentou, possivelmente devido às condições morfológicas e funcionais das bases apicais, na microssomia hemifacial. A má oclusão dentária foi corrigida parcialmente tanto pelo deslocamento das bases apicais, como pela adaptação dentoalveolar.

Sobre as estratégias de tratamento com aparelhos removíveis, CETLIN; TEN HOEVE ${ }^{29}$, em 1983, relataram que o aparelho de Shamy, para a correção unilateral da má oclusão de Classe II também apresenta vantagens e desvantagens. Similarmente aos elásticos de Classe II, os aparelhos removíveis dependem da cooperação por parte do paciente para se obter o 
sucesso ao final do tratamento. O aparelho de Shamy utiliza todo o arco dentário superior como ancoragem, possuindo uma mola de distalização unilateral que serve para corrigir a relação de Classe II, subdivisão. Afirmaram que um dos efeitos colaterais deste tratamento conservador implica na grande perda de ancoragem e conseqüente mesialização dos dentes ânterosuperiores, podendo ser ou não um efeito desejável.

Em 1986, KELLY ${ }^{68}$ apresentou um caso de má oclusão de Classe II, $1^{a}$ divisão, subdivisão, com sobremordida e sobressaliência acentuadas. A avaliação cefalométrica do paciente indicou uma biretrusão maxilar, contraindicando a realização de extrações para a correção do caso. Desta forma, optou-se pelo tratamento com aparelho fixo da técnica de Begg, associado a elásticos intermaxilares de Classe II. Observou-se uma boa colaboração do paciente, resultando após 22 meses, no término satisfatório do tratamento, com correção tanto da sobremordida como da sobressaliência, além de uma relação molar de Classe I.

PROFFIT ${ }^{96}$, também em 1986, admitiu que as discrepâncias menores de coordenação da linha média podem ser tratadas nos estágios finais com elásticos assimétricos intermaxilares de Classe II e III associados a um elástico diagonal anterior. Observou também que é bastante difícil corrigir discrepâncias acentuadas após o fechamento dos espaços de extração.

Em 1987, ALEXANDER ${ }^{4}$, indicou a utilização de elásticos anteriores pesados, associados a elásticos de Classe II e III, dependendo se a má oclusão original for de Classe II ou III. O procedimento é realizado durante os estágios de finalização, com exceção de casos com extrações em que este procedimento pode ser realizado durante o fechamento dos espaços, se 
houver uma discrepância significante da linha média. O elástico anterior é então adaptado às alças de retração.

Em 1987, MONGINI; SCHMID ${ }^{84}$ utilizaram uma amostra de 11 pacientes em crescimento com uma assimetria mandibular e um desvio do mento, mostrando em todos os casos uma má oclusão com deslocamento mandibular em idade precoce. Radiografias póstero-anteriores, laterais oblíquas, telerradiografias e transcranianas da ATM foram obtidas em máxima intercuspidação habitual, objetivando investigar se algumas assimetrias mandibulares eram adaptações do deslocamento mandibular durante o crescimento. Nas radiografias póstero-anteriores, sete pontos foram selecionados para definir as áreas mandibular, craniana superior e craniomandibular, bilateralmente. A posição do mais alto ponto condilar dentro da fossa glenóide foi digitada e avaliada. Os dados radiográficos foram obtidos e analisados novamente após a instalação dos aparelhos funcionais e ao final de um período de observação de 37,6 meses. Radiografias controle foram obtidas com intervalos de seis a 12 meses, constatando-se, após o período de observação, uma melhora significante da assimetria mandibular em nove dos onze clientes devido ao crescimento compensatório da mandíbula e do côndilo no lado afetado decorrente do deslocamento mandibular. Restabeleceram a normalização do padrão de crescimento por meio da terapia ortopédica. O avanço mandibular, promoveu um tensionamento dos músculos temporal e pterigóideo lateral, ocorrendo, conseqüentemente, uma remodelação óssea na região condilar e da fossa glenóide. Verificaram que dos 11 casos tratados, nove apresentaram uma mandíbula mais simétrica devido ao crescimento compensatório mandibular e condilar no lado que foi afetado, devido ao deslocamento mandibular. Concluíram, portanto, que tais assimetrias devem ser tratadas pelo restabelecimento do padrão de crescimento normal. 
JERROLD; LOWENSTEIN ${ }^{65}$, em 1990, discutiram o diagnóstico e tratamento da linha média. Todas as três linhas médias do paciente - facial, maxilar e mandibular - devem ser consideradas para se obter uma correção ideal. A correção da linha média deve começar desde o início do tratamento e uma vez corrigida, ela deve ser mantida como um guia para qualquer sistema de força a ser utilizado para completar o caso. Ilustraram graficamente quatro casos de desvio de linha média quando a face apresentava simetria e oito casos quando a face apresentava um certo grau de assimetria e discutiram os respectivos tratamentos. Os autores afirmaram que a maioria das formas de tratamento parece associar as discrepâncias de linha média e sua correção, tendo como causa um deslocamento mandibular ou uma rotação de algum tipo. Se o deslocamento ou a rotação não foram o fator causal e se o desvio da linha média foi o resultado de uma migração dentária, em uma face simétrica, então a utilização de certas mecânicas alteraria a posição mandibular, resultando em uma coordenação das linhas médias dentárias, deixando, entretanto, a face assimétrica. Se a mandíbula sofreu uma movimentação excêntrica e a articulação não é capaz de se adaptar, há o potencial para o desenvolvimento de uma disfunção da ATM. Afirmaram também que nos casos em que uma discrepância de linha média é muito pequena ( 1 a $2 \mathrm{~mm}$ ), existe a tendência de inclinar os dentes anteriores para uma posição coordenada com a linha média facial. Os autores acrescentam uma outra causa para o desvio da linha média, que é a retração acentuada dos caninos, de um lado, o que propicia um desvio da linha média após a retração descuidada dos dentes anteriores. Essa retração exagerada ocorre porque não se dispensa atenção suficiente à coordenação das três linhas médias do paciente. 
AZAZ; NITZAN; BRIN', em 1991, comentaram que o tratamento de escolha para os casos de hiperplasia condilar em estágio ativo deve ser a condilectomia com a correção cirúrgica simultânea ou posterior da assimetria facial. O processo de remodelação espontânea das estruturas faciais após a eliminação do côndilo hiperplásico em crescimento ativo pode melhorar a simetria, sem a necessidade de intervenções futuras. Desta forma, os autores descreveram dois casos em que as condilectomias foram realizadas após a confirmação do diagnóstico por meio da cintilografia. Após a cirurgia, observou-se uma melhora da simetria facial, bem como a correção do desvio do mento e dos dentes. A radiografia panorâmica revelou côndilos normais, enquanto a telerradiografia lateral expressou um perfil ortognático, na visão sagital. Concluíram que quando se planeja a condilectomia em pacientes com hiperplasia condilar, a correção simultânea da assimetria facial e da má oclusão devem ser levadas em consideração. A correção cirúrgica deve ser adiada a depender do grau da severidade da assimetria, além da própria opinião pessoal do paciente quanto à sua aparência facial.

$\mathrm{Na}$ apresentação de um caso clínico de um paciente adulto com má oclusão de Classe II, subdivisão, SEELY ${ }^{109}$ em 1993, mostrou a correção da assimetria, associada a um apinhamento moderado superior e inferior, em um perfil onde não se aceitava a realização de extrações. No plano de tratamento, foi proposta ao paciente uma tentativa de correção desta má oclusão com o uso de elásticos intermaxilares e aparelho extrabucal assimétrico, na dependência de sua colaboração para que fosse evitada a extração de um pré-molar superior no lado de Classe II. Apesar de não utilizar o aparelho extrabucal, a cooperação do paciente na utilização dos elásticos permitiu a obtenção de resultados favoráveis, com melhora do perfil facial e relação molar de Classe I, após um período de 22 meses. 
Em 1995, BERGAMINI; MELSEN ${ }^{11}$ afirmaram que a maioria dos casos de assimetria dentária apresenta uma história associada de perda precoce de molar decíduo com conseqüente migração mesial dos molares adjacentes. Comentaram que quando um dente se perde, o seu adjacente tende a migrar em direção ao espaço presente, e quando a perda ocorre unilateralmente, resulta numa assimetria dentária. Somente uma oclusão muito estável pode prevenir estas migrações secundárias. Descreveram um caso clínico em que foi realizada uma biomecânica com sistema assimétrico de força para a correção da linha média. A paciente de 24 anos apresentava uma relação de Classe II, subdivisão direita, uma sobressaliência de $11 \mathrm{~mm}$, uma sobremordida de $5 \mathrm{~mm}$ e um desvio de linha média dentária superior de $6 \mathrm{~mm}$ para a esquerda, além de um apinhamento nos incisivos inferiores. Pela análise cefalométrica, verificou-se um padrão braquicefálico, altura facial diminuída e um mau relacionamento entre as bases ósseas. Os incisivos superiores estavam suavemente vestibularizados e os inferiores lingualizados, apresentando interposição do lábio inferior. Como a paciente apresentava um odontoma envolvendo o incisivo lateral inferior esquerdo, este elemento dentário foi perdido, colapsando o arco na região do canino inferior esquerdo. Como tratamento, utilizou-se um arco segmentado para abertura de espaço para uma prótese adesiva na região do incisivo perdido, por meio de um sistema de forças assimétrico. Para tanto, forças de intrusão e inclinação nos incisivos inferiores foram utilizadas para correção da sobressaliência, finalizando-se o caso com as linhas médias dentárias coincidentes entre si. A paciente demonstrou grande satisfação com o resultado obtido com este planejamento.

Em 1995, JANSON et al. ${ }^{58}$, apresentaram um caso clínico de má oclusão de Classe II, subdivisão, com ligeiro apinhamento superior e inferior, desvio da linha média inferior para a direita e suave protrusão labial, tratado 
com extrações de dois pré-molares superiores e um pré-molar inferior, do lado da relação molar normal. Os resultados demonstraram uma relação normal de caninos, um ótimo relacionamento dos dentes anteriores e coincidência das linhas médias dentárias, possibilitando a obtenção de uma guia anterior imediata e um excelente perfil facial, comprovando a eficiência desta opção de tratamento nestes casos.

Para SHROFF; LINDAUER; BURSTONE ${ }^{115}$, em 1997, a mecânica de retração unilateral constitui-se num desafio, uma vez que causa inúmeros efeitos colaterais, durante o tratamento ortodôntico. Os autores comentaram sobre o diagnóstico diferencial e plano de tratamento das más oclusões de Classe II, subdivisão, baseando-se num tratamento biomecânico com momentos de inclinação. Preconizaram a correção da inclinação axial dos molares, utilizando a técnica do arco segmentado com momentos de retração unilateral no tratamento das assimetrias dentárias. Comentaram que esta técnica permite a aplicação de um sistema de forças diferenciado nos lados direito e esquerdo do arco, sem que ocorram efeitos indesejáveis, tais como: inclinação do plano oclusal, extrusão e mesialização das raízes dos molares e alterações no arco inferior decorrentes do uso de elásticos de Classe II. Utilizam a retração unilateral, principalmente, para corrigir a inclinação axial mesiodistal dos molares em casos de assimetrias dentárias e esqueléticas suaves, produzindo compensações dentárias

Em 1998, REBELLATO ${ }^{98}$ abordou diversas possibilidades de diagnósticos e possíveis planos de tratamento para a correção das más oclusões assimétricas. Observou que as assimetrias, as quais representam um desafio ao ortodontista do ponto de vista biomecânico, poderiam ser corrigidas por uma combinação de extrações assimétricas que facilitariam a 
mecânica intra e interarcos; além de reduzir a necessidade da colaboração do paciente no uso dos elásticos e reduzir o tempo de tratamento ativo.

Também em 1998, SHROFF; SIEGEL ${ }^{116}$ revisaram diversas estratégias de tratamento da má oclusão assimétrica, baseados na utilização de princípios de diagnóstico diferencial para a definição do plano de tratamento. Observaram que o desafio encontrado na correção das más oclusões assimétricas ocorre devido a um diagnóstico, muitas vezes, impreciso, no qual será baseada a mecânica ortodôntica. Abordaram que a realização de um diagnóstico diferencial cuidadoso tende a resultar em uma planificação capaz de alcançar o sucesso na correção destas más oclusões.

No mesmo ano, WOHL; BAMONTE; PEARSON ${ }^{142}$, apresentaram um caso clínico de uma paciente de 13 anos de idade com má oclusão de Classe II, subdivisão e apinhamento dentário superior, o que sugeriu um maior comprometimento assimétrico deste arco. Baseado nisto, decidiu-se pelo tratamento sem extrações e com a utilização de aparelho extrabucal com força excêntrica, associado ao aparelho fixo superior e inferior. Após 19 meses de fase ativa de tratamento, a paciente apresentou uma melhora da estética facial, relação molar de Classe I, além de uma sobremordida e sobressaliência normais.

Avaliando a correção das discrepâncias de linha média por meio da terapia combinada ortopédica-ortodôntica, ERDOGAN; ERDOGAN ${ }^{41}$, ainda em 1998, descreveram dois casos clínicos que mostravam assimetria facial moderada, desvio mandibular para um dos lados, perfil mole e sorriso normais. Em ambos os casos, uma Classe II subdivisão estava presente, sendo necessária uma mecânica assimétrica para o tratamento. Afirmaram que os elásticos intermaxilares assimétricos podem corrigir a linha média até 
3mm, porém forças extrusivas verticais dos elásticos de Classe III e diagonal anterior excedem o vetor de força do elástico de Classe II, do lado oposto. Portanto, o plano oclusal maxilar pode ficar mais baixo do lado da Classe II, causando dificuldades na mecânica com aparelhos fixos. Desta forma, utilizaram o jasper jumper assimetricamente, com a mecânica convencional de Classe II de um lado, e do outro, uma mecânica de Classe III, para corrigir a discrepância de linha média e um possível desvio mandibular, resultante de uma deficiência maxilar. Descreveram os efeitos dentoesqueléticos deste tipo de tratamento em um caso, na fase inicial da dentadura permanente, e outro, num paciente adulto. Os efeitos dentários deste sistema de força são recíprocos, ou seja, os incisivos movimentam-se de corpo em direções opostas, enquanto a direção e a quantidade do movimento são controladas pelo tamanho dos jumpers. Concluíram que em ambos os casos houve a correção das assimetrias dos arcos dentários e a estabilidade dos resultados. Os aparelhos foram bem aceitos pelos pacientes e nenhum índice de quebra foi registrado, mesmo tendo sido acoplados mesialmente aos tubos dos molares. Além de que houve menor manifestação de efeitos adversos em comparação com o uso dos elásticos intermaxilares.

SMITH; ALEXANDER ${ }^{122}$ relataram no ano de 1999, a correção ortodôntica de uma má oclusão de Classe II, divisão 1, subdivisão realizada sem extrações e com a utilização de um aparelho extrabucal cervical. Associada a esta má oclusão, o paciente apresentava uma mordida aberta anterior relacionada ao hábito de sucção do polegar, o qual foi removido durante o tratamento. A correção da Classe II, subdivisão, além do aparelho extrabucal, contou com a utilização de elásticos intermaxilares de Classe II e anterior para correção da linha média, tendo sido realizada em um total de 14 meses. Ao término do tratamento obteve-se uma relação molar de Classe I, associada a uma melhora da estética facial, relacionada principalmente ao 
crescimento substancial da mandíbula e à restrição do desenvolvimento maxilar.

Em 2000, SHELLEY et al. ${ }^{114}$ apresentaram um caso clínico de Classe II, divisão 2, subdivisão esquerda, associada à mordida cruzada posterior e anterior. Baseados em um diagnóstico que indicava mesialização do molar superior esquerdo por perda precoce do $2^{\circ}$ molar decíduo, decidiu-se pela realização de uma expansão superior seguido pela utilização de aparelho fixo superior e inferior, arco superior com ômegas alongados e extração do $1^{\circ}$ prémolar superior esquerdo. Após a correção das mordidas cruzadas, o paciente também utilizou elásticos intermaxilares para fechamento final do espaço. Com um tratamento ativo de 22 meses, atingiu-se uma estética facial e dentária favoráveis, com relação de caninos e de molar direito de Classe I e relação de molar esquerdo em Classe II.

$\mathrm{CRUZ}^{34}$, em 2000, avaliou as alterações dento-esqueléticas decorrentes do tratamento ortodôntico com extrações assimétricas de pacientes com má oclusão de Classe II, subdivisão, em relação a um grupo controle de oclusão normal. Para a realização deste estudo utilizou radiografias submentoniana e póstero-anterior. Verificou que as extrações assimétricas nas más oclusões de Classe II, subdivisão, acentuaram as diferenças nas posições ânteroposteriores direita e esquerda dos primeiros molares superiores e inferiores, como esperado com o protocolo de extrações utilizado. Também observou que o planejamento adotado foi eficaz em normalizar o posicionamento das linhas médias superior e inferior, sem causar inclinações indesejáveis do plano oclusal, tendo sido considerado uma modalidade terapêutica válida para a solução deste problema. 
Nos casos tratados com extrações simétricas, a utilização demasiada de elásticos intermaxilares e/ou de forças excêntricas para a correção da má oclusão de Classe II, subdivisão, também se apresenta como um fator muito desfavorável e arriscado, pois cria uma dependência muito maior da colaboração do paciente para que haja resultados satisfatórios quanto à relação oclusal final, segundo JANSON et al. ${ }^{59}$.

TANAKA; KREIA ${ }^{126}$, em 2002, comentaram sobre a importância no tratamento ortodôntico da busca de linhas medianas corretas. Enfatizaram que a avaliação das estéticas dentária e facial consiste num item importante no processo de diagnóstico, planejamento e execução do tratamento ortodôntico, sendo um dos maiores desafios deste trinômio o correto posicionamento das linhas medianas dentárias, superior e inferior, entre si. Os autores observaram que os desvios das linhas medianas podem ser tratados ortodonticamente com ou sem extrações dentárias, associadas ou não à ancoragem extrabucal e com elásticos intermaxilares, em grande parte dos casos, tendo apresentado casos clínicos tratados segundo estes distintos protocolos. Lembraram entretanto, que em casos onde a assimetria possui característica esquelética torna-se necessário a associação com cirurgia para que se otimize a estabilidade, a saúde periodontal e o equilíbrio facial.

Em 2003, SAKIMA et al. ${ }^{104}$ apresentaram um relato clínico do tratamento da Classe II, divisão 1, subdivisão, na fase de dentadura decídua ou mista, quando está envolvido o crescimento da mandíbula. Propuseram que, quando a Classe II subdivisão estiver relacionada com uma posição assimétrica da mandíbula nas fases precoces do desenvolvimento da dentição, uma opção terapêutica consiste na utilização de recursos ortodônticos que estimulem o crescimento da mandíbula unilateralmente, sem produzir inclinação do plano oclusal. Para tanto, apresentaram um caso clínico tratado com um aparelho 
idealizado pelos autores, que ativou o desenvolvimento unilateral do arco inferior, tendo obtido resultado satisfatório com efeitos ortopédicos durante a fase de crescimento.

Também em 2003, JANSON et al. ${ }^{62}$ verificaram o índice de sucesso do tratamento da má oclusão de Classe II, subdivisão, realizada com extrações simétricas e assimétricas. Para tanto utilizaram pares de modelos de gesso inicial e final que pertenciam a 28 pacientes Classe II, subdivisão, que foram tratados com extrações de quatro pré-molares e de 23 pacientes também Classe II, subdivisão, só que tratados com extrações de três pré-molares, sendo dois superiores e um inferior do lado da Classe I. Para realização desta avaliação utilizaram o índice de prioridade de tratamento (TPI). Verificaram diferenças estatisticamente significantes apenas quanto à correção da linha média dentária entre os grupos, onde o grupo corrigido com três extrações apresentou maior correção do desvio inicial. Observaram também uma tendência de ligeira superioridade dos resultados do tratamento realizado com extrações assimétricas sobre o realizado com quatro extrações.

Ainda em 2003, JANSON et al. ${ }^{61}$ publicaram a apresentação de quatro casos clínicos tratados com ortodontia corretiva, sendo três deles de má oclusão de Classe II, subdivisão. Ressaltaram a importância de um correto diagnóstico do comprometimento assimétrico e suas características, para então estabelecer um plano de tratamento para cada caso. Entre os três casos clínicos, um foi corrigido com extrações assimétricas de três prémolares, sendo dois superiores e um inferior do lado da Classe I; o segundo também recebeu extração assimétrica, entretanto de apenas um pré-molar superior do lado da Classe II devido ao desvio da linha média estar localizado no arco superior; e o terceiro caso recebeu tratamento precoce com a utilização de aparelho Occlus-o-Guide, corrigindo a má oclusão. Ao final os 
autores indicaram que todos os casos tiveram sucesso em seus resultados, incluindo a correção da linha média e a manutenção de harmonia do perfil facial presente ao início do tratamento.

\subsection{Extrações dentárias no tratamento da Classe II}

A correção ortodôntica realizada associada a extrações dentárias representa um recurso amplamente aceito e utilizado na literatura ${ }^{13,17,19,27,34,52,58,62,61,71,90,107,118,127}$. Entretanto, uma das principais preocupações nas indicações de extrações com finalidades ortodônticas consiste nas conseqüências dentoesqueléticas e tegumentares que serão obtidas.

Preocupando-se também com a harmonia das linhas faciais, TWEED ${ }^{129}$, em 1944, concluiu que o equilíbrio e a harmonia da estética facial são alcançados quando os incisivos inferiores são posicionados verticalmente em sua base óssea e portanto, a obtenção de uma "oclusão normal" pela terapia ortodôntica é bastante limitada. Desta maneira, quando ocorre discrepância entre as estruturas óssea e dentária, uma melhor estética facial será obtida com a remoção de dentes.

Segundo LITT et $a .^{75}$, em 1984, uma alternativa para a extração de quatro pré-molares no tratamento daqueles casos de má oclusão de Classe II em que provavelmente há uma insuficiência de crescimento ósseo, consiste em remover apenas os dois primeiros pré-molares superiores. Isso permitiria uma redução da protrusão da pré-maxila, a eliminação da sobressaliência excessiva, e possibilitaria o estabelecimento da atividade normal da musculatura peribucal. Além disso, os movimentos radiculares dos dentes em 
casos tratados com duas extrações são mais fáceis quando comparados aos casos de extrações de quatro pré-molares, diminuindo também o tempo de tratamento.

Segundo ARVYSTAS ${ }^{8}$, em 1985, a extração deve ser evitada enquanto houver crescimento ântero-posterior da maxila e da mandíbula. Ao apresentar o tratamento de um caso clínico de Classe II de Angle, a extração dentária foi contra-indicada em razão do perfil facial reto apresentado inicialmente pelo paciente, sendo realizada mecânica com força extrabucal e elásticos intermaxilares.

SILVA ${ }^{118}$, em 1988, realizou um estudo cefalométrico semilongitudinal de jovens brasileiras, leucodermas, tratadas ortodonticamente, portadoras inicialmente de Classes I e II, divisão 1, e compararam com as medidas de uma amostra de oclusão normal. Utilizou um grupo de 18 jovens com má oclusão de Classe I e outro de 26 jovens com Classe II, todas tratadas com aparelho fixo e extração dos quatro primeiros pré-molares. O tipo de ancoragem extrabucal utilizada, quando necessária, não foi padronizado. Verificou que o grupo composto por jovens com Classe II apresentou uma restrição significante da protrusão maxilar com o tratamento, enquanto a mandíbula cresceu de forma natural, refletindo na melhora do relacionamento maxilomandibular. Observou uma redução tanto da inclinação como da protrusão dos incisivos inferiores, que foram retraídos com a mecânica empregada.

VIG et al. ${ }^{136}$, em 1990, avaliaram a interferência entre as extrações dentárias e a duração do tratamento ortodôntico corretivo, realizado em cinco clínicas ortodônticas de Michigan (E.U.A.). Observaram um tempo de tratamento maior para os casos corrigidos com extração. A duração do 
tratamento realizado também foi influenciada pelo fator da intervenção ortodôntica ser apenas superior ou nos dois arcos dentários.

Ao avaliar os efeitos da idade do paciente nos resultados do tratamento ortodôntico, HARRIS; DYER; VADEN ${ }^{49}$, em 1991, realizaram um estudo cefalométrico do tratamento da má oclusão de Classe II, tratada com aparelho fixo de Edgewise e extração de quatro pré-molares. Utilizando a análise de Johnston, verificaram que o crescimento mandibular foi responsável por $70 \%$ da correção total da relação molar nos pacientes jovens, enquanto nos adultos esta correção ocorreu exclusivamente devido à movimentação dentária. Independente da idade dos pacientes, a mecânica empregada propiciou significante retrusão dos incisivos.

Também avaliando a duração do tratamento ortodôntico, FINK; $\mathrm{SMITH}^{42}$, em 1992, estudaram 118 pacientes corrigidos com ortodontia corretiva fixa. Verificaram que o principal fator que influenciou no aumento do tempo de correção foi o número de pré-molares extraídos. Casos tratados sem extração dentária apresentaram uma duração média de 21,95 meses, enquanto casos corrigidos apenas com extração de pré-molares superiores foram concluídos em 25,0 meses e casos com extração de quatro pré-molares em 26,18 meses, em média.

Um estudo longitudinal comparando o tratamento ortodôntico da má oclusão de Classe II, com a mecânica de Edgewise, em pacientes limítrofes tratados com e sem extrações dos pré-molares foi realizado por PAQUETTE; BEATTIE; JOHNSTON JUNIOR ${ }^{90}$, em 1992. Observaram que em ambos os grupos o principal responsável pela correção da relação molar e da sobressaliência foi o crescimento da mandíbula. Os pacientes tratados sem extração de pré-molares apresentaram uma protrusão anterior mais 
acentuada, tanto ao término do tratamento como após um controle de dez anos, enquanto na amostra corrigida com extrações verificaram a presença de um perfil mais achatado, nos mesmos períodos de avaliação.

BISHARA et al. ${ }^{12}$, em 1994, compararam os efeitos da correção ortodôntica da má oclusão de Classe II, realizada com extração de quatro prémolares e sem extrações dentárias. Avaliaram estes grupos em relação a uma amostra de jovens com oclusão satisfatória. Ao início do tratamento, observaram que o grupo tratado com extrações apresentava uma protrusão mais acentuada dos lábios superior e inferior. Ao término do tratamento ortodôntico ambos os grupos apresentavam normalização das relações esqueléticas, comparativamente ao apresentado pelo grupo controle. Observaram efeitos diferenciados quanto ao relacionamento dentário e à proeminência labial entre os casos tratados com e sem extrações. Ao final da correção, o grupo tratado com extrações apresentou uma maior retrusão dos incisivos superiores e inferiores, assim como um posicionamento mais retruído dos lábios, em comparação ao grupo com oclusão satisfatória. No grupo corrigido sem extrações, constataram uma relativa tendência de maior protrusão tanto dos incisivos como dos lábios.

Em 1995, BISHARA et al ${ }^{13}$ avaliaram cefalometricamente as alterações dentofaciais e tegumentares proporcionadas pelo tratamento ortodôntico da Classe II sem extrações dentárias e com extrações de quatro primeiros prémolares. Verificaram que ao início do tratamento os pacientes do grupo com extrações apresentaram uma maior protrusão dos lábios superior e inferior. Ao término da correção, os pacientes tratados com extrações apresentavam um perfil labial mais retruído, enquanto o grupo sem extrações possuía uma maior protrusão labial. Os casos corrigidos com extrações dos quatro pré- 
molares apresentaram um perfil facial mais reto e os incisivos superiores e inferiores mais verticalizados, ao término do tratamento ortodôntico.

Em 1996, SCANAVINI; VIGORITO ${ }^{107}$, avaliaram as alterações ortodônticas e ortopédicas resultantes da técnica de Arco de Canto, aplicada em jovens com má oclusão de Classe II, divisão 1, realizada com extrações de quatro pré-molares. Para tanto analisaram telerradiografias laterais de um grupo de 40 pacientes, de ambos os sexos, com idade variando entre 11 e 14 anos. Verificaram que a fase de retração anterior foi a responsável pelas alterações dentoesqueléticas mais significantes, tendo observado uma efetiva modificação do padrão facial, uma retrusão dos dentes anteriores, diminuindo a protrusão dentária, e uma perda de ancoragem dos molares. Também constataram o aumento do comprimento do corpo e ramo da mandíbula e a diminuição da convexidade do perfil ósseo. Concluíram neste estudo que o tratamento ortodôntico-ortopédico realizado com extrações proporcionou alterações significantes na posição ântero-posterior dos incisivos, assim como retração do perfil tegumentar.

Em 1998, HOLMAN et al. ${ }^{53}$ avaliaram tratamentos ortodônticos corretivos realizados sem extração e com extração de quatro pré-molares, utilizando um índice de determinação por observação clínica (PAR). Verificaram que os pacientes do grupo tratado com extrações apresentavam maior apinhamento anterior e maior sobressaliência, ao início da correção. Com a correção realizada, os dois grupos apresentaram significante melhora da relação dento-oclusal, sendo que ao término da correção apresentavam índices estatisticamente semelhantes. Observaram que o tratamento ortodôntico realizado com extrações de quatro pré-molares foi 3,7 meses mais longo, em média, quando comparado com os pacientes tratados sem extração. 
CARVALHO ${ }^{27}$, em 2000, avaliou cefalometricamente o tratamento corretivo da má oclusão de Classe II, divisão 1, realizado com extrações de quatro pré-molares e utilização de ancoragem extrabucal cervical, comparando os resultados de acordo com o padrão de crescimento facial de cada grupo de pacientes. Para tanto utilizou 120 telerradiografias (60 iniciais e 60 finais), de sessenta pacientes com esta má oclusão, divididos em dois grupos de trinta segundo o padrão vertical de crescimento facial. Neste estudo pode verificar que ocorreu retrusão significante dos incisivos superiores e inferiores com o tratamento realizado com quatro extrações, independente do padrão facial do paciente.

Ao avaliar a qualidade de finalização do tratamento ortodôntico da Classe II completa, realizado com duas ou com quatro extrações de prémolares, BRAMBILLA ${ }^{17}$, em 2002, utilizou o índice de prioridade de tratamento (IPT) nas fases inicial e final dos tratamentos. Neste estudo, verificou que os pacientes tratados com duas extrações superiores apresentaram resultados melhores quanto à qualidade do tratamento, em relação aos jovens tratados com quatro extrações. A diferença entre os índices iniciais e finais do tratamento foram mais favoráveis ao grupo tratado com extração apenas dos pré-molares superiores principalmente quanto: a relação ântero-posterior final dos caninos, a quantidade de sobressaliência e a quantidade de sobremordida.

Também em 2002, JANSON et al. ${ }^{60}$ publicaram um trabalho sobre a influência do padrão facial na decisão de extrações, discutindo sobre a importância de uma correta análise do padrão facial do paciente quando do planejamento e tratamento ortodôntico. Ao apresentar dois casos clínicos, tratados de maneiras distintas, mostrou que um importante fator na decisão 
de extrair ou não em casos ortodônticos consiste no padrão facial de cada paciente.

\subsection{Estética facial e o perfil tegumentar}

Ao longo de muitos anos, os trabalhos cefalométricos enfatizavam principalmente as alterações esqueléticas, decorrentes do tratamento ortodôntico, e pouca ênfase era dedicada ao perfil tegumentar, principalmente devido à suposição de que se a má oclusão fosse corrigida de maneira satisfatória, o posicionamento harmonioso do tecido facial mole ocorreria automaticamente ${ }^{108,135}$.

De acordo com o preceito exposto acima, TWEED ${ }^{130}$, em 1954, propôs a determinação da estética facial, baseada em estruturas dentoesqueléticas e representada por um triângulo formado pelo plano horizontal de Frankfort, pelo plano mandibular e pelo longo eixo do incisivo inferior. Os ângulos internos formados foram denominados de FMA (Frankfort Mandibular Angle), FMIA (Frankfort Mandibular Incisor Angle) e IMPA (Incisor Mandibular Plane Angle). Segundo o autor, a estética facial seria obtida, seguindo-se os valores normativos propostos nesse estudo, principalmente de acordo com o IMPA, identificando a necessidade ou não de extrações para a boa finalização do tratamento ortodôntico.

Analisando cefalometricamente e por meio de fotografias uma amostra de 52 adultos, 3 do sexo masculino e 49 do feminino, leucodermas, constituída de vencedores de concursos de beleza, modelos profissionais e atores considerados belos e atraentes pela população, PECK; PECK ${ }^{91}$, em 
1970, observaram que houve uma maior predileção popular por um padrão dentofacial mais protruído.

Objetivando determinar a capacidade de percepção do próprio perfil facial e os fatores associados a esta capacidade, HERSHON; GIDDON ${ }^{51}$, em 1980 , fotografaram o perfil de 42 pacientes tratados ortodonticamente e 42 sem tratamento. A partir das fotografias, traçaram o perfil facial e apresentaram estes traçados aos pacientes para que pudessem apontar qual o seu próprio perfil e qual o que gostariam de ter. Os resultados indicaram uma grande variação na capacidade de percepção do próprio perfil nos 2 grupos avaliados, porém ambos aceitaram um perfil com protrusão labial como estético. Os autores sugeriram um maior cuidado por parte dos profissionais na obtenção do perfil ideal, em detrimento ao perfil "normal" aceito pelos pacientes.

Investigando sobre as implicações estéticas das más oclusões na aparência dentofacial, SHAW et al. ${ }^{112}$, em 1985, determinaram se a atratividade de jovens adultos seria modificada pela sua aparência estética. Utilizaram cinco diferentes disposições fotográficas, em preto e branco, de dois homens e duas mulheres, modificando-as de modo que, em cada versão a face era padronizada, excetuando o problema estético dentário. Os cinco tipos de face de cada paciente diagramadas artificialmente apresentaram os seguintes condições: incisivos bem posicionados, incisivos proeminentes, incisivo lateral superior ausente, incisivos excessivamente apinhados e fenda labial unilateral. Oitocentos adultos foram convocados para julgar estas 20 faces, utilizando escores para estimar a característica individual social de cada face. Concluíram que as faces que apresentavam os incisivos alinhados e nivelados apresentaram mais atratividade, socialização, popularidade e sinônimo de inteligência. As faces com os incisivos proeminentes receberam 
conceitos de fidelidade e honestidade, enquanto que as faces com fissura unilateral receberam os menores pontos de estética facial. Desta forma, afirmaram que os pacientes que apresentavam dentes bem posicionados eram mais atraentes socialmente.

Com o propósito de demonstrar as limitações inerentes à utilização de padrões ortodônticos internacionais, baseados principalmente em estudos de leucodermas ocidentais, na avaliação de diferentes grupos étnicos, SATRAVAHA; SCHLEGEL ${ }^{106}$, em 1987, analisaram o perfil facial de 180 jovens do sexo feminino, divididos em 2 grupos. O primeiro contou com 70 jovens de origem chinesa e idades entre 16 e 21 anos e o segundo com 110 jovens de origem tailandesa e idades entre 16 e 19 anos. Os resultados demonstraram uma face mais protruída em $75 \%$ a $84 \%$ dos casos. A convexidade do perfil apresentou-se menor em relação aos valores normativos. Não houve diferença significante do perfil para os dois grupos analisados. Os autores enfatizaram a necessidade de pesquisar os padrões estéticos nos diferentes grupos étnicos para obter valores normativos próprios de cada grupo, permitindo uma maior facilidade no diagnóstico e no planejamento ortodôntico e não se basear em valores alienígenas que desnorteariam a peculiaridade étnica.

Comparando a estética facial entre jovens brasileiros com oclusão normal, de acordo com a análise de Burstone, FISMANN; VIGORITO ${ }^{43}$, em 1987, utilizaram uma amostra de 54 telerradiografias em norma lateral e 54 modelos de gesso de jovens de ambos os sexos, leucodermas, com idades entre 12 e 18 anos. Os resultados revelaram um perfil facial mais convexo no sexo masculino, porém, de um modo geral, ambos os sexos demonstraram diferenças significantes em relação aos valores preconizados por BURSTONE ${ }^{22}$. $\mathrm{Na}$ análise individual da estética facial, os autores observaram 
uma grande variação dos valores cefalométricos considerados. Os autores concluíram que para um correto planejamento ortodôntico, deve-se considerar as características étnicas como também a individualização das metas a serem alcançadas.

Propondo-se a fornecer dados complementares sobre alguns valores normativos de interesse clínico a respeito das dimensões do tecido tegumentar facial em jovens leucodermas, ZYLINSKI; NANDA; KAPILA ${ }^{144}$, em 1992, utilizaram uma amostra composta por 60 jovens com uma estética agradável, um perfil facial equilibrado e uma relação normal do trespasse vertical e horizontal. Jovens que apresentavam as características acima, mesmo tendo uma má oclusão, não foram descartados da pesquisa. A amostra foi dividida em dois grupos com idades diferentes. O primeiro grupo, composto por cefalogramas de 31 jovens que apresentavam idades entre 5 e 10 anos, média de 7,6 anos e o segundo grupo, composto por 29 cefalogramas de adultos jovens com idades entre 22 e 32 anos, média de 26,2 anos. Os objetivos específicos desse estudo definiam normas das variáveis do perfil, avaliavam diferenças estatisticamente significantes dos valores médios obtidos em ambos os grupos, propunham um método para avaliação das proporções sagitais do nariz, mento e lábios e determinavam normas para essas proporções. Os resultados mostraram que o ângulo nasolabial e o mentolabial não diferiram significantemente entre os dois grupos. A convexidade facial tegumentar total evidenciou uma pequena diferença significante entre os grupos avaliados. As demais variáveis exibiram diferenças estatisticamente significantes. Os lábios apresentaram-se mais retruídos em relação à linha $E$ de Ricketts, no segundo grupo. Concluíram que o perfil tegumentar facial mostrou-se relativamente mais reto no segundo grupo quando comparado ao primeiro. 
Visando quantificar a associação entre a avaliação objetiva de medidas cefalométricas representativas das alterações ântero-posteriores dentárias e esqueléticas e a percepção subjetiva da beleza facial, TULLOCH; PHILLIPS; DANN ${ }^{128}$, em 1993, utilizaram uma amostra de 18 jovens, apresentando desde uma relação ântero-posterior próxima ao ideal até uma relação severa de Classe II, com idades entre 15 e 31 anos. Transparências coloridas do perfil facial, frontal da face com e sem sorriso de cada paciente foram avaliadas por três grupos diferentes: 16 residentes em ortodontia, 17 alunos de odontologia e 71 alunos de psicologia, que determinaram subjetivamente a atratividade facial. As tomadas radiográficas foram realizadas com os jovens em posição natural da cabeça e os cefalogramas foram digitalizados em computador. Os ângulos S.N.A, S.N.B e A.N.B e a medida linear da sobressaliência foram utilizados como referências cefalométricas na determinação das discrepâncias ântero-posteriores. Os resultados demonstraram uma associação entre o grau de sobressaliência e a determinação da atratividade facial entre os três grupos de avaliadores.

VERDONCK et al. ${ }^{134}$, também em 1993, analisaram a relação existente entre as alterações das áreas labiais e as estruturas faciais esqueléticas e dentárias, no plano sagital mediano. Com o auxílio de um planímetro, obtiveram-se as áreas labiais de 156 telerradiografias laterais de pacientes com idades de 6 a 14 anos, previamente ao tratamento ortodôntico. Estes jovens foram divididos em 18 grupos de acordo com a idade, o sexo e o tipo de má oclusão. Todas as tomadas radiográficas foram realizadas com os lábios em posição de repouso. Os resultados mostraram que a linha labial e a inclinação sagital dos incisivos foram significantemente diferentes em toda a amostra. Não houve diferença estatística da altura facial inferior nas 3 Classes de má oclusão, segundo a classificação de Angle. Houve uma relação significante entre a área labial inferior e a inclinação sagital dos incisivos e 
também com a posição da maxila e da mandíbula. A área labial inferior exibiu também uma relação significante com a inclinação do incisivo superior na Classe I e com a inclinação do incisivo inferior na Classe II, divisão 1. Os autores concluíram que a área labial, especialmente a superior não se apresentou como um bom indicador do desenvolvimento facial e dentário.

Com o objetivo de analisar, cefalometricamente, as possíveis alterações longitudinais no perfil facial tegumentar de jovens brasileiros, no período dos 13 aos 18 anos de idade, bem como a presença de dimorfismo sexual, SCAVONE JUNIOR ${ }^{108}$, em 1996, utilizou a amostra de jovens leucodermas, com oclusão normal da Disciplina de Ortodontia da Faculdade de Odontologia de Bauru, Universidade de São Paulo. Essa amostra englobava 129 telerradiografias em norma lateral, de 21 jovens do sexo masculino e 22 do feminino. Para cada jovem, foram selecionadas 3 telerradiografias longitudinais, com um intervalo médio de 2 anos entre elas, representando aproximadamente as idades de 13, 15 e 17 anos. Denominou-se de primeiro período de crescimento ao intervalo compreendido entre as duas primeiras telerradiografias, de segundo período de crescimento ao intervalo entre as duas últimas e de período total, ao intervalo entre a primeira e a última telerradiografia. Os resultados demonstraram um aumento da espessura dos tecidos moles na maioria das regiões do perfil facial, para o sexo masculino e apenas na região subnasal, para o feminino. Houve um aumento da convexidade do perfil total, no sexo masculino e uma diminuição no feminino. A altura dos componentes faciais aumentou em ambos os sexos, sendo mais significante no masculino e ocorreu principalmente na região do lábio inferior e do mento e em menor proporção na região do lábio superior. Houve também uma maior participação proporcional da altura facial ântero-inferior e da altura conjunta do lábio inferior e do mento, em relação à altura facial total, verificando-se o oposto para a altura nasal e um maior crescimento ântero- 
posterior e vertical em todas as regiões faciais, excetuando-se apenas os incrementos da altura do lábio superior, no primeiro período e da altura nasal, no segundo.

IAGUE NETO56, em 1998, avaliou a relação entre o perfil facial tegumentar e as estruturas dentoesqueléticas maxilomandibulares. Utilizou uma amostra de 49 telerradiografias tomadas de adultos jovens, sendo 27 do sexo feminino (média de 17 a 9m) e 22 do masculino (média de 17a 10m), com oclusão normal e boa estética facial. De acordo com os resultados obtidos, observou-se que o perfil facial tegumentar, avaliado por meio de medidas angulares, não demonstrou um dlmorfismo sexual. Houve uma correlação entre a linha dentoalveolar superior, tomada do ponto A ao ponto vestibular do incisivo superior, e a inclinação do lábio superior. A inclinação do incisivo inferior em relação à linha $\mathrm{N}$ perpendicular ao plano de Frankfort (Nperp) influenciou a inclinação do lábio inferior.

Ainda em 1998, DAINESI ${ }^{36}$, avaliou cefalometricamente a influência dos padrões extremos de crescimento facial sobre o perfil tegumentar, utilizando uma amostra de 38 jovens leucodermas, com oclusão satisfatória e sem tratamento ortodôntico, sendo 19 deles com padrão vertical e os 19 restantes com crescimento horizontal. Estes jovens foram avaliados em cinco fases entre as idades de 6 e 18 anos. Os resultados indicaram que não houve influência do padrão de crescimento sobre as alterações em espessura do perfil tegumentar e que a convexidade facial diminuiu em ambos padrões de crescimento.

Em 1999, CARVALHO et al. ${ }^{26}$, realizaram um estudo sobre a proporção de retração dos lábios em relação à retração dos incisivos em pacientes com maloclusão Classe II, divisão I de Angle tratados com a técnica de arco de 
canto e extração de pré-molares. Compararam por meio de cefalometria pré e pós-tratamento, as medidas de 27 pacientes divididos em dois números: 14 pacientes tratados com extrações de dois pré-molares superiores e 13 pacientes tratados com extrações de quatro pré-molares. Apesar da ausência de diferença estatística entre os grupos, houve uma ligeira tendência para maior retração dos lábios no grupo tratado com extrações de quatro prémolares.

CAPELLI JUNIOR; TIBANA ${ }^{25}$, em 2002, avaliaram cefalometricamente as alterações no perfil facial em 40 indivíduos jovens submetidos a tratamento ortodôntico com extrações de quatro pré-molares. Não existiu padronização da má oclusão inicial, entretanto todos os pacientes foram tratado com aparelho fixo de Edgewise. Verificaram uma significante retrusão labial com o tratamento, que pode ser correlacionada com redução da variável IMPA. Segundo os autores, nos pacientes que pertenciam a esta amostra, esta retrusão dos incisivos inferiores e conseqüente reposicionamento labial foi benéfico esteticamente, uma vez que estes pacientes apresentavam visível protrusão tegumentar inicial.

Ainda em 2002, KOCADERELI ${ }^{69}$ avaliou as alterações no perfil tegumentar em função do tratamento ortodôntico realizado com ou sem extrações. Para tanto, avaliou cafalometricamente 80 pacientes com má oclusão de Classe I, sendo 40 tratados sem extrações e os outros 40 tratados com extrações dos quatro primeiros pré-molares. Concluiu que a principal diferença do perfil tegumentar entre os grupos ao término do tratamento consistiu num posicionamento dos lábios superior e inferior mais retruídos nos casos tratados com extrações. 
Em 2003, ALMEIDA; MAZZIEIRO5 , comentaram sobre fatores da estética facial relevantes no diagnóstico e no planejamento ortodôntico, tendo como objetivo alertar os profissionais da ortodontia quanto à necessidade de se avaliar criteriosamente as características da face dos planejamentos ortodônticos. Os autores lembram que a beleza mostra-se altamente subjetiva e densamente influenciada por aspectos sociais, raciais, étnicos e psicológicos. Além disso, ressaltam que o equilíbrio estético sempre deve considerar a idade do paciente e o ortodontista deve ter a capacidade de visualizar seus pacientes nas fases mais avançadas da vida.

Uma avaliação quanto à preferência estética do perfil tegumentar, avaliado por leigos e ortodontistas, em relação aos padrões cefalométricos existentes foi realizada por DIOGO; BERNARDES ${ }^{38}$, também em 2003, onde interpretaram o perfil facial de 90 jovens tratados ortodonticamente. Os perfis foram avaliados por 30 examinadores, sendo 15 ortodontistas especialistas e 15 leigos em Ortodontia. Verificaram que os ortodontistas foram mais criteriosos e severos na avaliação do perfil facial, em relação aos leigos. Os resultados obtidos permitiram concluir que a preferência estética apresentouse com tendência significativa a uma leve protrusão dos lábios superior e inferior.

Com o intuito de avaliar os efeitos das extrações de pré-molares na curvatura dos lábios superior e inferior, WHOLLEY; WOODS ${ }^{139}$, em 2003, realizaram um estudo cefalométrico com 80 casos tratados com extrações dentárias. Realizaram comparações entre as alterações labiais nos casos tratados com extrações dos quatro primeiros pré-molares, nos casos com extrações dos quatro segundos pré-molares e em casos tratados com extrações dos primeiros pré-molares superiores e segundos inferiores. Verificaram que as alterações da profundidade de ambos os lábios não 
apresentou relação com as diferenças nos protocolos de extrações estudados. Concluíram que na prática ortodôntica a escolha dos dentes que serão extraídos baseia-se em diversas razões, não devendo ser definida apenas pelas alterações no perfil tegumentar.

Pelo que foi demonstrado, existem diversos trabalhos que comentam a correção da má oclusão de Classe II, subdivisão, realizada com extrações dentárias, simétricas ou assimétricas. A literatura também demonstra a ocorrência de uma maior retração dos incisivos e, conseqüentemente, do perfil tegumentar, em pacientes tratados com extrações, fator que favorece o raciocínio de uma maior retrusão dentária e tegumentar nos casos de Classe II, subdivisão, tratados com quatro extrações, em relação aos corrigidos com extrações assimétricas de três pré-molares. No entanto, a ausência de uma avaliação científica que comprove esta linha de raciocínio, representa maior motivação para o desenvolvimento desta pesquisa. 


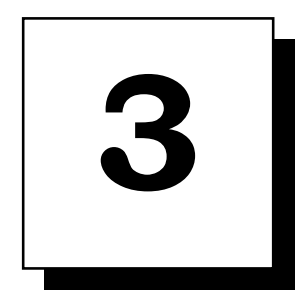

PROPOSIÇÃO 


\section{PROPOSIÇÃO}

A proposição desta pesquisa consiste em comparar os resultados cefalométricos esqueléticos, dentários e tegumentares de casos com má oclusão de Classe II, subdivisão, tratados com extrações assimétricas de três pré-molares, sendo dois superiores e um inferior, com aqueles tratados com extrações simétricas de quatro pré-molares. A seguinte hipótese nula será testada: "Não há diferença entre as alterações cefalométricas de casos com má oclusão de Classe II subdivisão, tratados com extrações assimétricas de três pré-molares, com aqueles tratados com extrações simétricas de quatro pré-molares". 


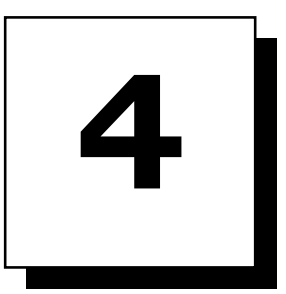

MATERIAL

E MÉTODOS 


\section{MATERIAL E MÉTODOS}

\subsection{Material}

Procedeu-se à seleção da amostra, de caráter retrospectivo, a partir do arquivo da Disciplina de Ortodontia da Faculdade de Odontologia de Bauru Universidade de São Paulo, FOB-USP, que conta com documentações de cerca de 4000 pacientes tratados.

A amostra para a execução deste estudo constou de 116 telerradiografias em norma lateral, 58 iniciais e 58 finais, tomadas de 58 pacientes com má oclusão de Classe II, subdivisão de Angle, com características semelhantes, tratados pelos alunos do curso de pósgraduação e especialização desta Disciplina, divididos em dois grupos distintos de acordo com o planejamento proposto para a correção desta má oclusão. Todos os pacientes selecionados para compor a amostra apresentavam as seguintes características em comum, utilizadas como critérios para seleção:

1. Possuir todos os dentes permanentes superiores e inferiores, até os primeiros molares, irrompidos ao início do tratamento;

2. Apresentar uma má oclusão de Classe II, subdivisão, com relação molar de Classe II completa de um dos lados;

3. Inexistência de histórico de trauma facial e deformidades craniomaxilofaciais que poderiam favorecer um crescimento assimétrico das bases ósseas $57,59,79,97,101,119$; 
4. Não deveriam ter sido anteriormente submetidos a tratamento ortodôntico.

A amostra foi dividida em dois grupos, de acordo com o protocolo de extrações utilizado para a realização do tratamento ortodôntico. Dessa forma, o grupo 1 ficou constituído por 29 pacientes tratados com extrações assimétricas de três pré-molares, sendo dois superiores e um inferior, do lado da relação de Classe I. As figuras 1 e 2 ilustram os modelos iniciais e finais de um caso de Classe II, subdivisão, tratado com este protocolo de extrações. Já o grupo 2 foi formado por 29 pacientes que receberam extrações simétricas de quatro pré-molares, dois superiores e dois inferiores. As figuras 3 e 4 mostram os modelos iniciais e finais de um caso clínico de Classe II, subdivisão, tratado com quatro extrações. Os dois grupos apresentavam semelhança quanto à quantidade média do apinhamento ântero-inferior inicial. Enquanto o grupo 1 possuía um apinhamento ântero-inferior inicial médio de 2,81mm (D.P.=1,38 / Máx. 5mm / Mín. 0mm), o grupo 2 apresentava uma média de 2,94mm (D.P.=1,62 / Máx. 6mm / Mín. Omm), denotando em semelhança estatística dos grupos quanto ao apinhamento inicial $(p=0,728959)$.

Em cada um dos grupos, 25 pacientes foram tratados utilizando a técnica de Edgewise Simplificada, enquanto os outros quatro pacientes tiveram seus tratamentos realizados com aparelhos pré-ajustados, considerados uma evolução natural da mecânica de Edgewise. Os grupos também apresentaram uma distribuição semelhante quanto ao gênero dos pacientes, sendo que para cada protocolo de tratamento estudado havia 13 pacientes do gênero masculino e 16 pacientes do gênero feminino. As médias das idades iniciais e finais dos pacientes e a diferença entre estas duas médias, encontram-se dispostos na tabela 1, dividida de acordo com cada grupo. Dentre os 58 
pacientes da amostra, 51 apresentavam má oclusão de Classe II, divisão 1, subdivisão (24 do grupo 1 e 27 do grupo 2) , enquanto apenas 7 pacientes tinham Classe II, divisão 2, subdivisão, sendo cinco deles pertencentes ao grupo 1 e os dois restantes faziam parte do grupo 2. As extrações realizadas nos pacientes atingiram principalmente os primeiros pré-molares, sendo que em apenas quatro pacientes do grupo 1 e três do grupo 2 foram realizadas extrações dos segundos pré-molares, na maioria das vezes devido a maior comprometimento de sua estrutura dentária. Apesar desta distinção, entre qual o dente extraído, estar presente dentro dos grupos, o trabalho de WHOLLEY; WOODS ${ }^{139}$, demonstrou que esta diferença não apresenta qualquer conseqüência nos resultados da mecânica empregada, quanto ao perfil labial.

Tabela 1 - Médias das idades iniciais e finais dos pacientes nos dois grupos e suas diferenças.

\begin{tabular}{c|c|c|c|c|c|c|c|c}
\hline \multirow{2}{*}{ FASES } & \multicolumn{5}{|c|}{ GRUPO 1 } & \multicolumn{5}{c}{ GRUPO 2 } \\
\cline { 2 - 9 } & Média & D.P. & Máximo & Mínimo & Média & D.P. & Máximo & Mínimo \\
\hline INICIAL & 14,28 & 1,74 & 17,17 & 11,42 & 13,15 & 1,49 & 15,75 & 10,00 \\
\hline FINAL & 16,90 & 1,90 & 19,50 & 13,67 & 15,64 & 1,33 & 18,00 & 13,42 \\
\hline $\begin{array}{c}\text { DIFERENÇA } \\
\text { MÉDIA }\end{array}$ & \multicolumn{3}{|c|}{2,62} & \multicolumn{5}{c}{2,49} \\
\hline
\end{tabular}



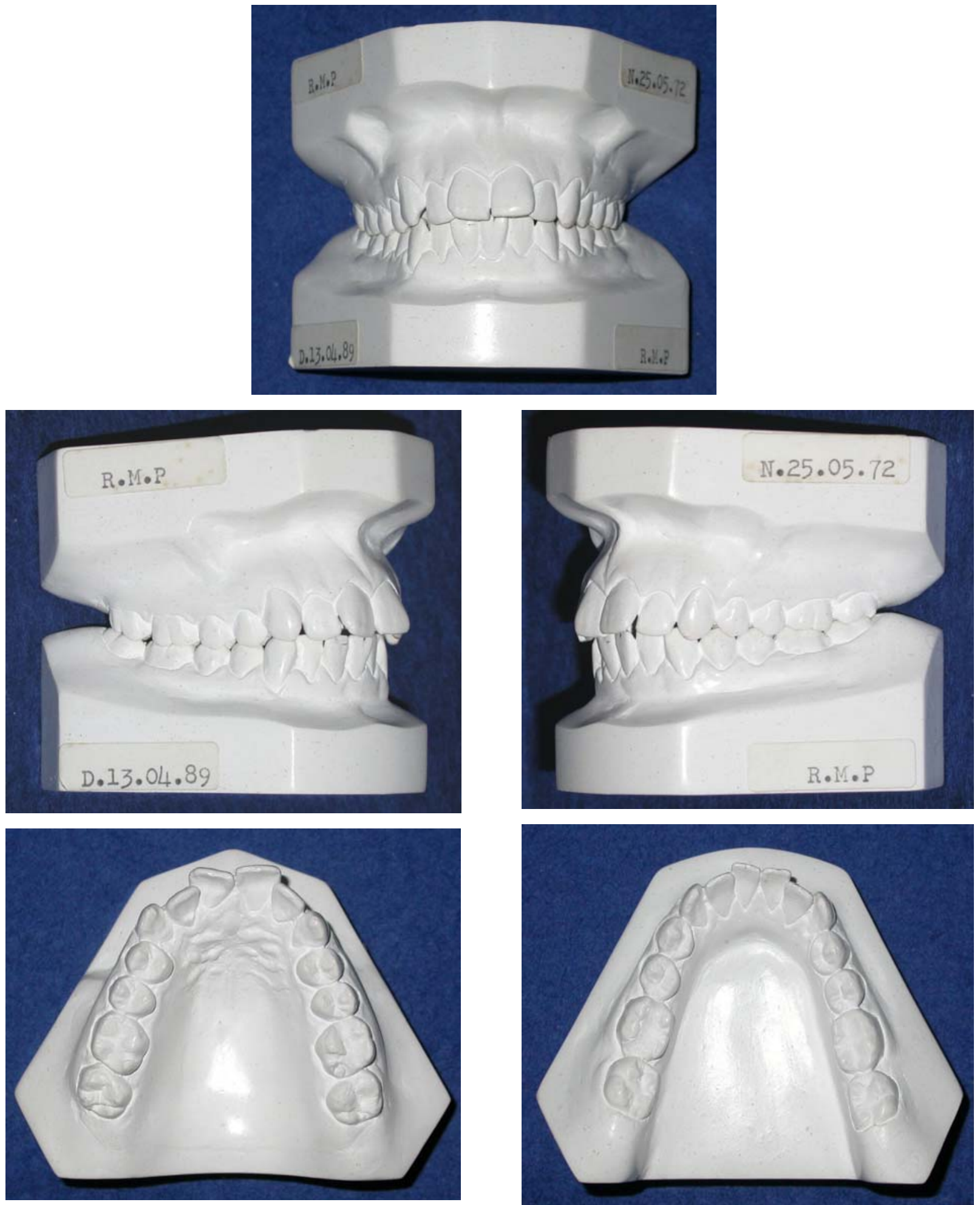

Figura 1: Modelos iniciais de caso de Classe II, subdivisão, tratado com extrações de três pré-molares. 

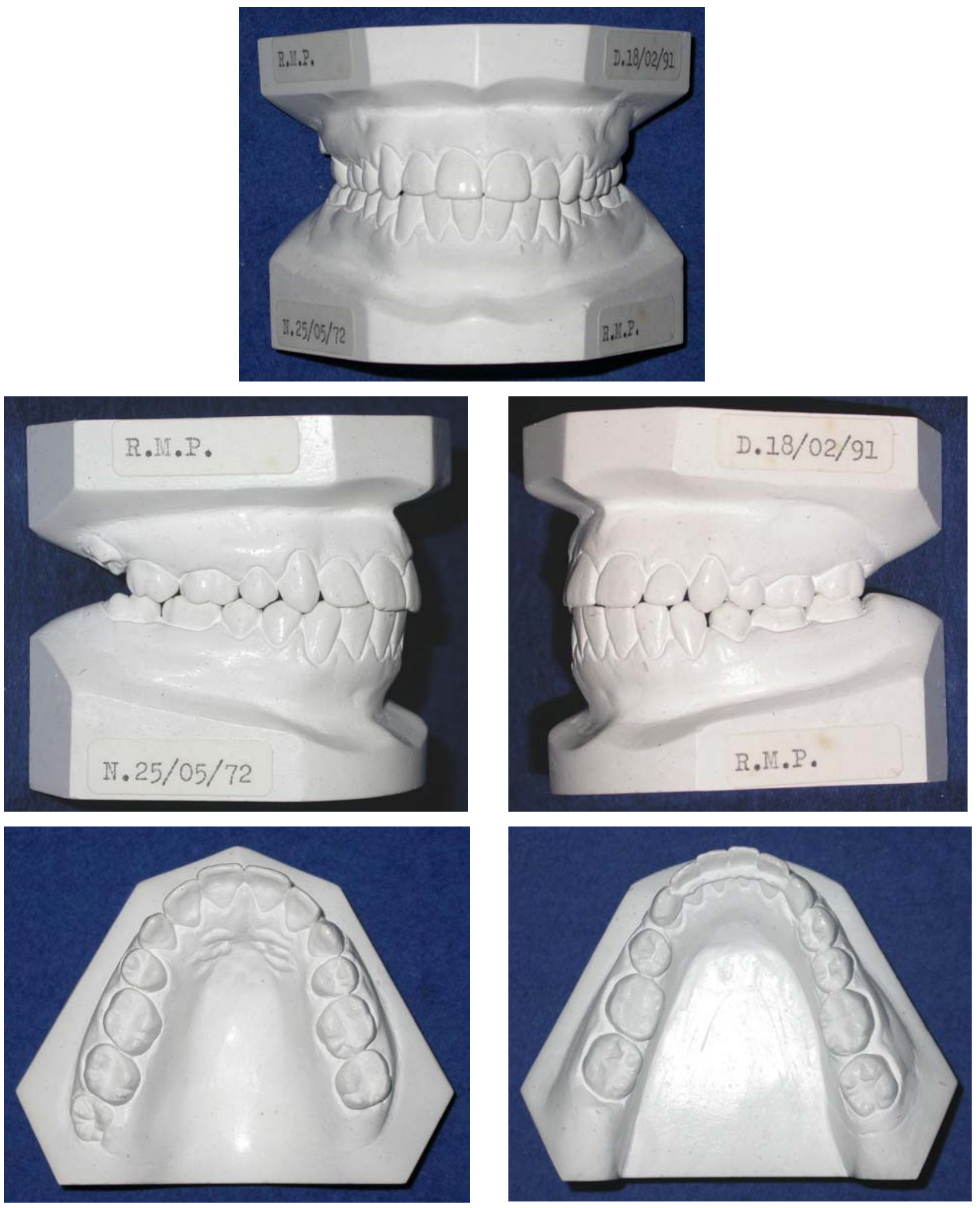

Figura 2: Modelos finais de caso de Classe II, subdivisão, tratado com extrações de três pré-molares. 

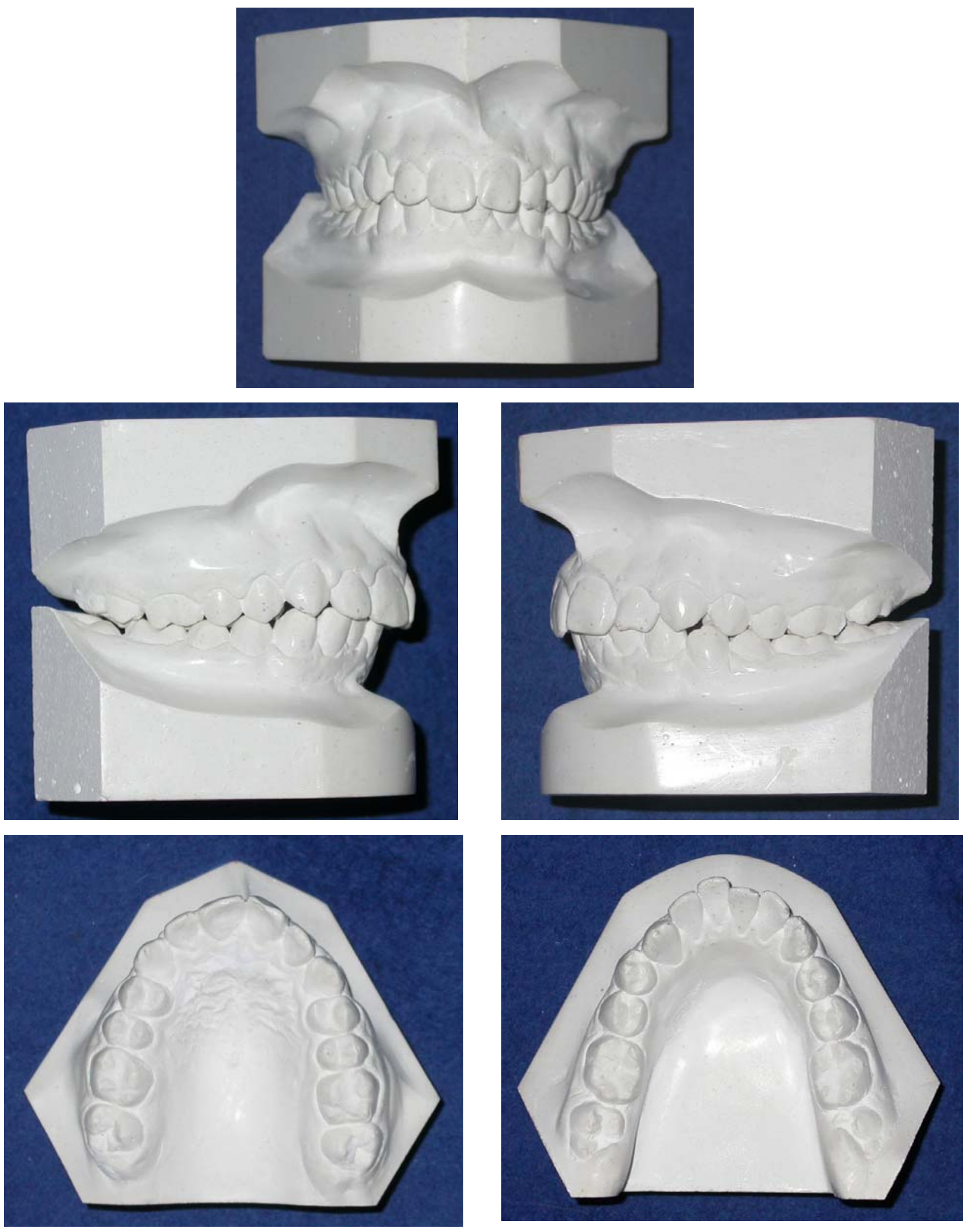

Figura 3: Modelos iniciais de caso de Classe II, subdivisão, tratado com extrações de quatro pré-molares. 

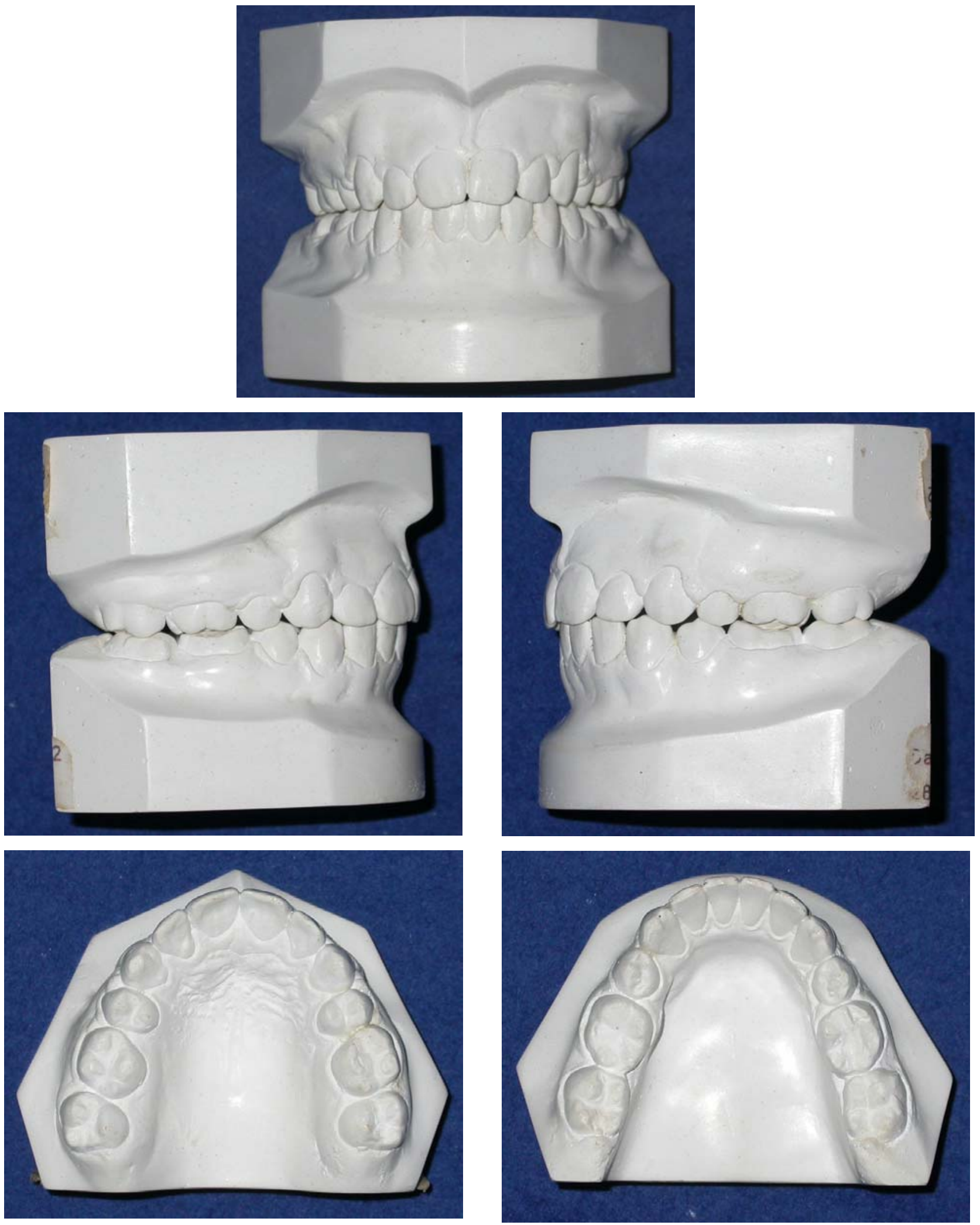

Figura 4: Modelos finais de caso de Classe II, subdivisão, tratado com extrações de quatro pré-molares. 


\subsection{Métodos}

\subsubsection{Obtenção das Telerradiografias Laterais}

As telerradiografias laterais utilizadas para o estudo foram obtidas dos pacientes com os lábios em repouso e na posição de máxima intercuspidação habitual, com o auxílio do cefalostato de Broadbent para um posicionamento padronizado da cabeça, seguindo as normas técnicas de obtenção e revelação preconizadas pela Disciplina de Radiologia da Faculdade de Odontologia de Bauru - Universidade de São Paulo, FOB-USP. Para cada paciente foram utilizadas duas telerradiografias laterais, uma correspondendo ao momento inicial do tratamento (T1) e a outra imediatamente após o final do tratamento ativo (T2).

Todas as telerradiografias da amostra foram realizadas em sete diferentes aparelhos, pois, para que houvesse um número suficiente de pacientes em cada grupo, necessitou-se selecionar a amostra a partir das documentações ortodônticas de todos os pacientes já tratados pela Disciplina de Ortodontia. Para aumentar a confiabilidade dos resultados deste estudo, foi realizada a determinação da magnificação de cada aparelho.

Os diferentes tipos de aparelhos cefalométricos utilizados apresentaram porcentagens distintas de magnificação, que variaram entre 6\% e 10,94\%. 


\subsubsection{Traçado e Medição das Radiografias}

Sobre cada telerradiografia adaptou-se uma folha de papel poliéster, tipo "ultraphan", de $0.07 \mathrm{~mm}$ de espessura, de $17,5 \times 17,5 \mathrm{~cm}$. O traçado anatômico e a demarcação dos pontos de referência dentoesqueléticos e tegumentares foram efetuados manualmente pelo autor com lapiseira de $0.3 \mathrm{~mm}$, sobre um negatoscópio, emoldurado com máscara de cartolina preta, em sala escurecida. Estes pontos foram posteriormente digitalizados, com auxílio de uma mesa digitalizadora Numonics AccuGrid XNT ${ }^{1}$, modelo A30TL.F, interligada a um microcomputador. Os traçados, assim como as mensurações, foram realizados pelo programa Dentofacial Planner $7.02^{2}$, efetuando-se por meio deste a correção da magnificação de cada imagem radiográfica.

Para que fosse possível a posterior medição de grandezas que avaliassem a quantidade de assimetria de determinadas estruturas, além da realização de medidas cefalométricas clássicas, optou-se pela realização de um segundo cefalograma sobre cada telerradiografia. Em um primeiro cefalograma foram delimitadas as médias das estruturas bilaterais, além das estruturas localizadas na linha mediana. Realizou-se então um segundo cefalograma, de modo que as estruturas onde se pretendia medir as assimetrias, tiveram suas imagens bilaterais traçadas de modo independente, lados direito e esquerdo. Assim cada para cada telerradiografia foram obtidos dois cefalogramas: um com o traçado duplo das estruturas pares e o outro com o traçado médio destas estruturas.

\footnotetext{
${ }^{1}$ Numonics Corp., Montgomeryville, Pennsylvania, United States of América.

2 Dentofacial Planner Software Inc., Toronto, Ontario, Canada
} 


\subsubsection{Traçado Anatômico}

Em um primeiro cefalograma foram delimitados os traçados médios das seguintes estruturas dentoesqueléticas e tegumentares:

1. osso esfenóide;

2. ossos nasais e frontal;

3. sela túrcica;

4. meato acústico externo;

5. órbita;

6. fissura pterigomaxilar;

7. maxila;

8. contorno completo da mandíbula;

9. incisivos centrais superiores e inferiores;

10. primeiros molares permanentes superiores e inferiores;

11. perfil tegumentar.

Em seguida realizou-se um segundo cefalograma com delimitação individualizada das imagens bilaterais das seguintes estruturas dentoesqueléticas:

1. órbita;

2. fissura pterigomaxilar;

3. contorno completo da mandíbula;

4. primeiros molares permanentes superiores e inferiores. 
Neste segundo cefalograma também foi realizado o traçado das seguintes estruturas localizadas no plano sagital mediano:

1. osso esfenóide;

2. ossos nasais e frontal;

3. sela túrcica;

\subsubsection{Pontos Cefalométricos de Referência}

Os pontos de referência anatômicos demarcados sobre o cefalograma com traçado médio das estruturas bilaterais seguem as demarcações e definições apresentadas por KROGMAN; SASSOUNI ${ }^{70}$ (1957), MCNAMARA JUNIOR $^{81}$ (1984) e STEINER ${ }^{124}$ (1962).

1. S Sela: ponto central da concavidade óssea da sela túrcica;

2. N Násio: ponto anterior da sutura frontonasal;

3. Po Pório: ponto superior do meato acústico externo;

4. Or Orbitário: ponto médio mais inferior da margem infraorbitária;

5. ENA Espinha Nasal Anterior: ponto mais anterior do soalho da fossa nasal;

6. ENP Espinha Nasal Posterior: ponto mais posterior do soalho da fossa nasal;

7. A Subespinhal: ponto mais profundo da concavidade anterior da maxila;

8. B Supramentoniano: ponto mais profundo da concavidade anterior da mandíbula;

9. Gn Gnátio: ponto mais ântero-inferior sobre o contorno na sínfise mentoniana; 
10. Me Mentoniano: ponto mais inferior do contorno da sínfise mentoniana;

11. Co Condílio: ponto mais póstero-superior do contorno do côndilo mandibular;

12. Go Gônio: ponto mais póstero-inferior da curva entre o corpo e o ramo mandibular;

13. Pt Fissura Pterigomaxilar: ponto mais posterior e superior de fissura pterigomaxilar;

14. Ls Labial Superior: ponto mais proeminente do lábio superior;

15. Li Labial Inferior: ponto mais proeminente do lábio inferior;

16. Pg' Pogônio Tegumentar: ponto mais anterior do mento tegumentar

17. Pn Ponta do Nariz: ponto mais proeminente do contorno nasal

18. U6 Cúspide do Molar Superior: ponta da cúspide mésio-vestibular do primeiro molar superior permanente;

19. U6d Borda Distal do Molar Superior: ponto mais posterior da face distal do primeiro molar superior permanente;

20. L6 Cúspide do Molar Inferior: ponta da cúspide mésio-vestibular do primeiro molar inferior permanente;

21. L6d Borda Distal do Molar Inferior: ponto mais posterior da face distal do primeiro molar inferior permanente;

22. U1 Borda Incisal do Incisivo Superior: ponto mais inferior da borda incisal do incisivo central superior;

23. U1' Raiz do Incisivo Superior: ápice da raiz do incisivo central superior;

24. U1v Vestibular do Incisivo Superior: ponto localizado na maior curvatura da face vestibular do incisivo central superior;

25. L1 Borda Incisal do Incisivo Inferior: ponto mais superior da borda incisal do incisivo central inferior;

26. L1' Raiz do Incisivo Inferior: ápice da raiz do incisivo central inferior; 
27. L1v Vestibular do Incisivo Inferior: ponto localizado na maior curvatura da face vestibular do incisivo central inferior.

Sobre o segundo cefalograma, com traçado duplo das estruturas bilaterais, os pontos de referência anatômicos demarcados seguiram as demarcações e definições apresentadas por ALAVI; BEGOLE; SCHNEIDER ${ }^{3}$ (1988).

1. S Sela: ponto central da concavidade óssea da sela túrcica;

2. N Násio: ponto mais anterior da sutura frontonasal;

3. Ba Básio: projeção do ponto ântero-inferior do forame magno;

4. OrA Orbitário Anterior: ponto mais inferior da margem infraorbitária da órbita anterior;

5. OrP Orbitário Posterior: ponto mais inferior da margem infraorbitária da órbita posterior;

6. PtmA Pterigomaxilar Anterior: ponto inferior da fossa pterigopalatina anterior, onde intersecciona o palato duro;

7. PtmP Pterigomaxilar Posterior: ponto inferior da fossa pterigopalatina posterior, onde intersecciona o palato duro;

8. AGoA Antegônio Anterior: ponto mais profundo na concavidade da borda inferior do contorno mandibular anterior;

9. AGoP Antegônio Posterior: ponto mais profundo na concavidade da borda inferior do contorno mandibular posterior;

10. GoA Gônio Anterior: ponto mais póstero-inferior da curva entre o corpo e o ramo do contorno mandibular anterior;

11. GoP Gônio Posterior: ponto mais póstero-inferior da curva entre o corpo e o ramo do contorno mandibular posterior; 
12. ArA Articular Anterior: ponto localizado na intersecção do contorno inferior do osso esfenóide com o contorno posterior do côndilo mandibular anterior;

13. ArP Articular Posterior: ponto localizado na intersecção do contorno inferior do osso esfenóide com o contorno posterior do côndilo mandibular posterior;

14. RaA Borda Anterior do Ramo Anterior: ponto mais posterior sobre o bordo anterior do ramo mandibular anterior;

15. RaP Borda Anterior do Ramo Posterior: ponto mais posterior sobre o bordo anterior do ramo mandibular posterior;

16. U6dA Borda Distal do Molar Superior Anterior: ponto mais posterior da face distal do primeiro molar superior permanente anterior;

17. U6dP Borda Distal do Molar Superior Posterior: ponto mais posterior da face distal do primeiro molar superior permanente posterior;

18. L6dA Borda Distal do Molar Inferior Anterior: ponto mais posterior da face distal do primeiro molar inferior permanente anterior;

19. L6dP Borda Distal do Molar Inferior Posterior: ponto mais posterior da face distal do primeiro molar inferior permanente posterior;

\subsubsection{Linhas e Planos de Referência}

Sobre o cefalograma onde foi delimitado o traçado médio das estruturas bilaterais, realizaram-se a demarcação das seguintes linhas e planos de referência:

01. Linha da base do crânio (SN) - da sela túrcica ao násio;

02. Linha NA - do násio ao subespinhal; 
03. Linha NB - do násio ao supramentoniano;

04. Linha A-perp - perpendicular ao plano de Frankfurt, passando pelo subespinhal;

05. Linha B-perp - perpendicular ao plano de Frankfurt, passando pelo supramentoniano;

06. Linha $\mathrm{H}$ - do pogônio tegumentar ao labial superior;

07. Plano de Frankfurt (Po-Or) - do pório ao orbitário;

08. Plano palatino (ENA-ENP) - da espinha nasal anterior à espinha nasal posterior;

09. Plano mandibular (Go-Me) - do gônio ao mentoniano;

10. Plano mandibular (Go-Gn) - do gônio ao gnátio;

11. Plano Vertical Pterigóideo (PTV) - perpendicular ao plano de Frankfurt, passando pelo ponto fissura pterigomaxilar;

12. Longo eixo do incisivo superior (U1-U1') - da borda incisal do incisivo superior à raiz do incisivo superior;

13. Longo eixo do incisivo inferior (L1-L1') - da borda incisal do incisivo inferior à raiz do incisivo inferior.

Sobre o segundo cefalograma, com traçado duplo das estruturas bilaterais, apenas as duas linhas de referência abaixo foram demarcadas:

01. Linha da base do crânio (SN) - da sela túrcica ao násio;

02. Linha Ba-perp - perpendicular à linha da base do crânio (SN), passando pelo básio; 


\subsubsection{Medidas Cefalométricas}

Para a obtenção das medidas cefalométricas, utilizou-se o primeiro cefalograma, com o traçado médio das estruturas bilaterais, para as variáveis relativas aos itens de 4.2.6.1 até 4.2.6.4. Apenas para a realização do ïndice de assimetria (item 4.2.6.5) é que foi utilizado o segundo cefalograma, com traçado duplo das estruturas bilaterais.

\subsubsection{Relação das bases ósseas (Figura 5)}

A. SNA - ângulo formado pelas linhas SN e NA;

B. SNB - ângulo formado pelas linhas SN e NB;

C. ANB - diferença dos ângulos SNA e SNB;

D. Co-A - comprimento efetivo da maxilla, distância entre o ponto condílio e o subespinhal;

E. Co-Gn - comprimento efetivo da mandíbula, distância entre o ponto condílio e o gnátio;

F. Dif. Mx.-Md. - diferença maxilomandibular, diferença das grandezas Co-Gn e Co-A;

\subsubsection{Padrão do esqueleto cefálico (Figura 5)}

G. SN.GoGn - ângulo formado pela linha SN e pelo plano mandibular Go$\mathrm{Gn}$;

H. FMA - ângulo formado pelos planos de Frankfurt e mandibular Go-Me;

I. AFAI (ENA-Me) - distância entre a espinha nasal anterior e o ponto mentoniano, mede a altura facial antero-inferior; 


\subsubsection{Perfil Tegumentar (Figura 5)}

J. H.NB - ângulo formado pelas linhas H e NB;

K. H-Pn (H-Nariz) - distância perpendicular da ponta do nariz à linha $\mathrm{H}$;

L. H-Li - distância perpendicular do labial inferior à linha $H$;

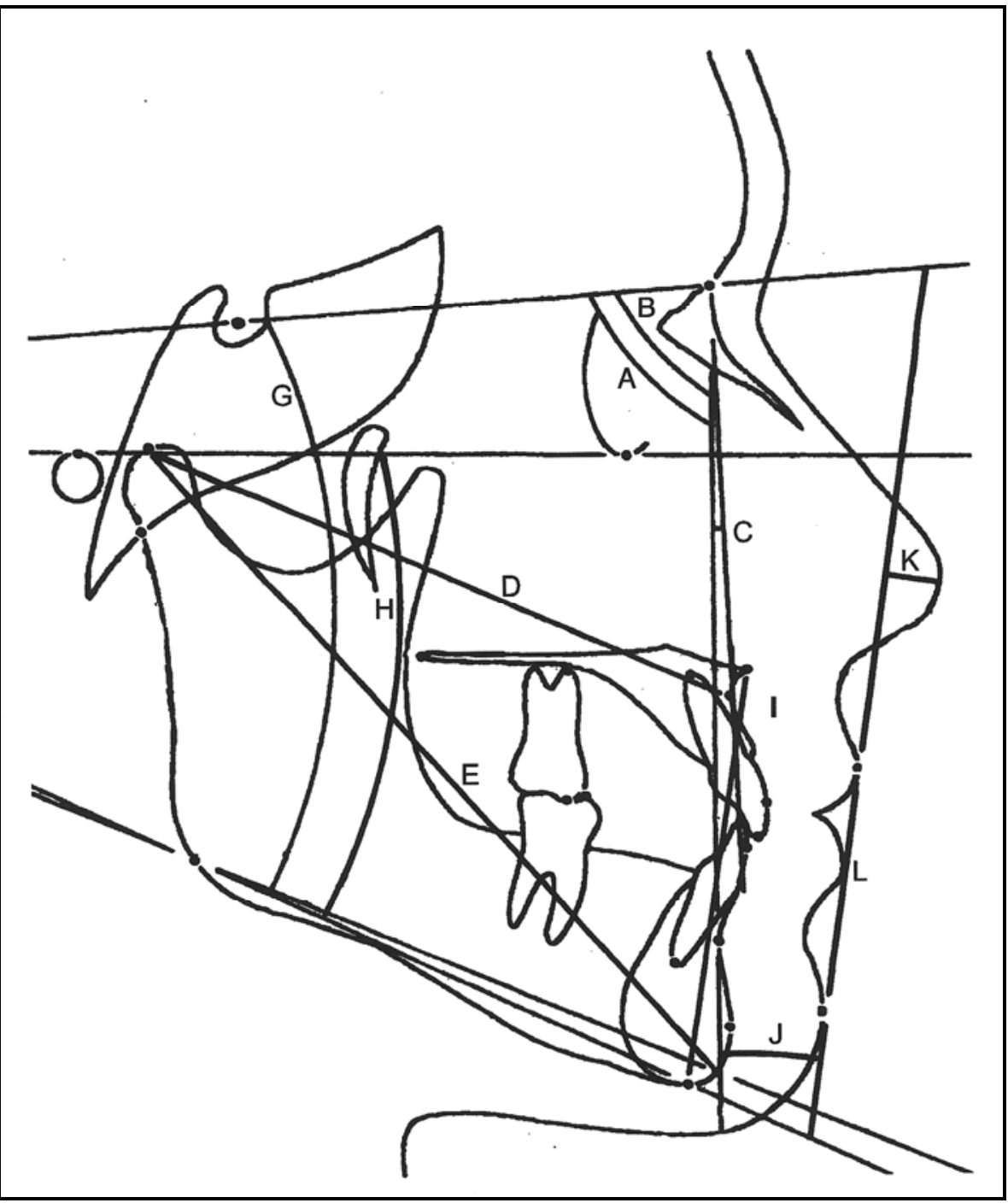

FIGURA 5: Grandezas cefalométricas esqueléticas e tegumentares. 


\subsubsection{Componente dentoalveolar (Figura 6)}

M. U1.NA - ângulo formado entre o longo eixo do incisivo superior e a linha $\mathrm{NA}$;

N. U1-NA - distância perpendicular da parte mais anterior do incisivo superior à linha NA;

O. U1.PP - ângulo formado pelo longo eixo do incisivo superior e o plano palatino;

P. U1-Aperp. - distância perpendicular da vestibular do incisivo superior à linha A-perp;

Q. U1-PP - distância perpendicular da borda incisal do incisivo superior ao plano palatino;

R. L1.NB - ângulo formado entre o longo eixo do incisivo inferior e a linha $\mathrm{NB}$;

S. L1-NB - distância perpendicular da parte mais anterior do incisivo inferior à linha NB;

T. L1.PM - ângulo formado pelo longo eixo do incisivo inferior e o plano mandibular Go-Me;

U. L1-Bperp. - distância perpendicular da vestibular do incisivo inferior à linha B-perp;

V. L1-PM - distância perpendicular da borda incisal do incisivo inferior ao plano mandibular Go-Me;

W. U6-PTV - distância perpendicular da borda distal do molar superior ao plano vertical pterióideo;

X. U6-PP - distância perpendicular da cúspide mesial do molar superior ao plano palatino; 
Y. L6-PTV - distância perpendicular da borda distal do molar inferior ao plano vertical pterióideo;

Z. L6-PM - distância perpendicular da cúspide mesial do molar inferior ao plano mandibular Go-Me;

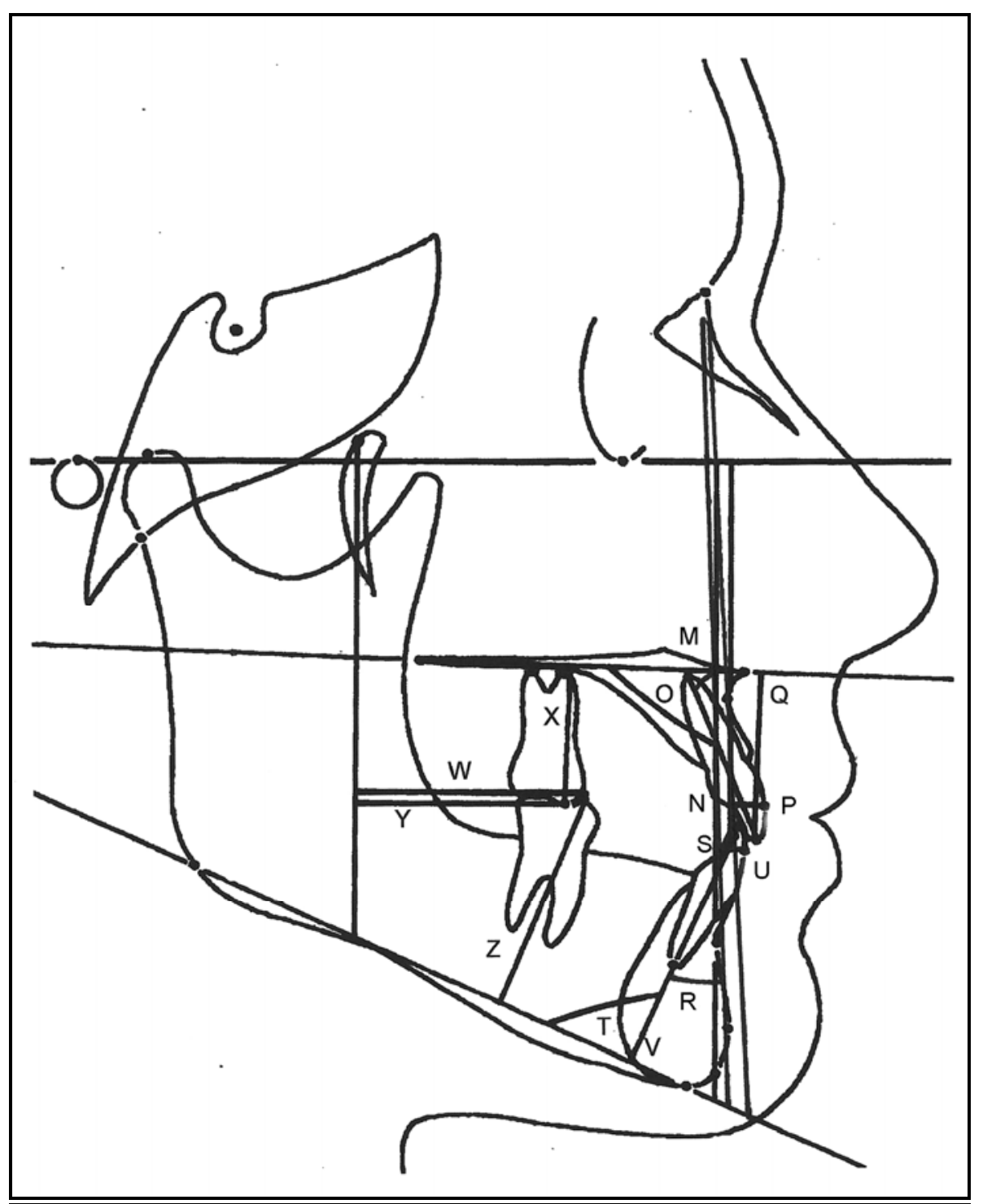

FIGURA 6: Grandezas cefalométricas dentárias. 


\subsubsection{5 Índices de assimetrias (Figura 7)}

A. Maxila - média simples das diferenças absolutas entre os valores obtidos, para os lados direito e esquerdo, das distâncias perpendiculares entre a linha Ba-perp e os pontos orbitário e pterigomaxilar;

B. Mandíbula - média simples das diferenças absolutas entre os valores obtidos, para os lados direito e esquerdo, das distâncias perpendiculares entre a linha Ba-perp e os pontos articular, gônio, antegônio e ramo anterior.

C. Molar Superior - diferença absoluta entre os valores obtidos, para os lados direito e esquerdo, da distância perpendicular entre a linha Baperp e a borda distal do molar superior;

D. Molar Inferior - diferença absoluta entre os valores obtidos, para os lados direito e esquerdo, da distância perpendicular entre a linha Baperp e a borda distal do molar inferior; 


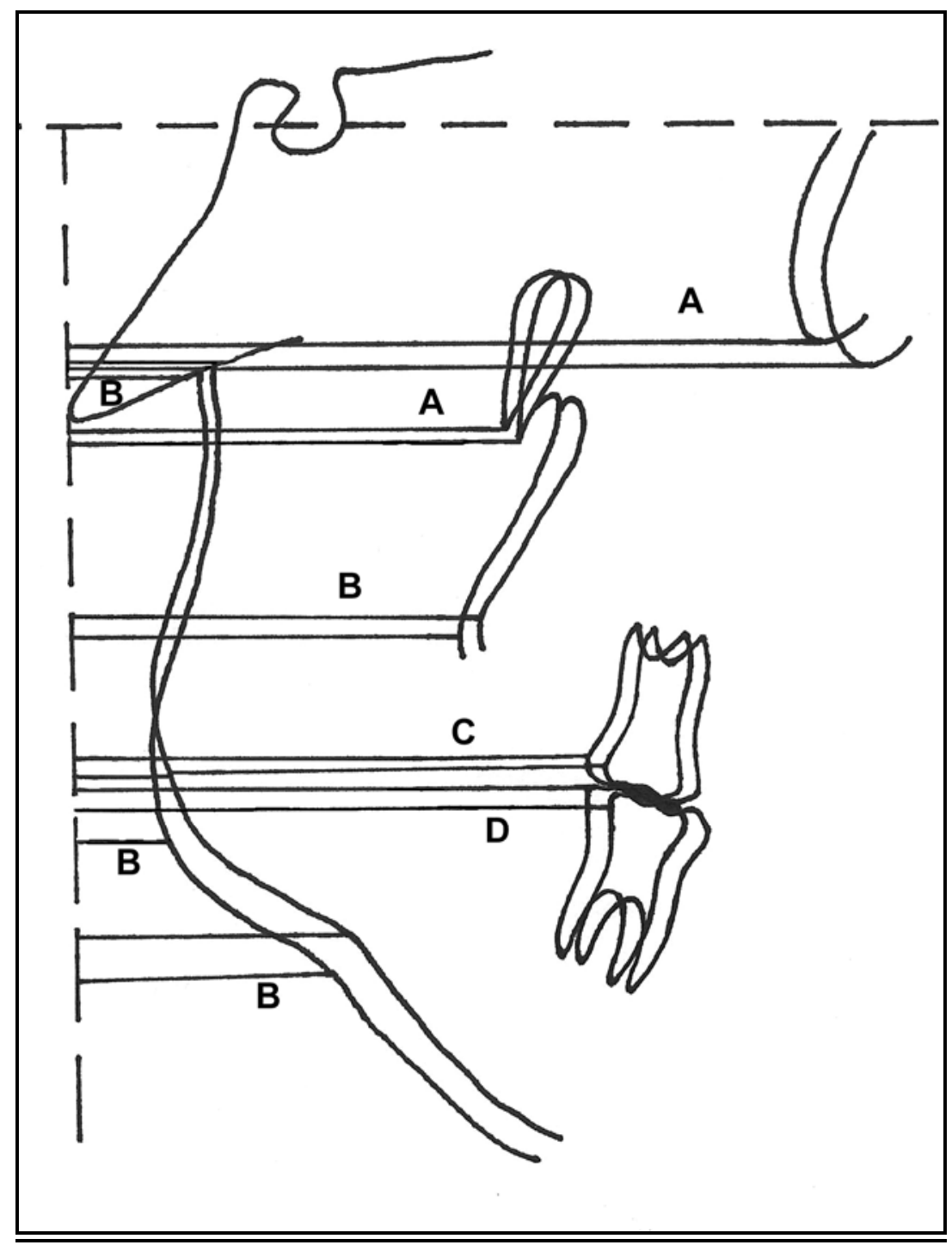

FIGURA 7: Grandezas cefalométricas pertinentes aos índices de assimetria.

\subsubsection{Análise Estatística}

\subsubsection{Erro do método}

Para avaliar a confiabilidade dos resultados desta pesquisa, procurouse determinar o erro metodológico intra-examinador. Para tanto, após um 
intervalo de 21 dias da realização dos cefalogramas que compuseram a amostra, foram novamente realizados os desenhos anatômicos e demarcados os pontos de referência sobre dez telerradiografias, selecionadas de forma aleatória, que anteriormente pertenceram à amostra pesquisada. Em seguida, estes cefalogramas foram transferidos para o computador, onde realizou-se as mensurações, obtendo-se os valores das grandezas cefalométricas.

O erro sistemático foi obtido de acordo com o teste "t" dependente, ao nível de significância de 5\%, de acordo com BAUMRIND, FRANTZ ${ }^{10}$, GRAVELY, BENZIES ${ }^{48}$; HOUSTON ${ }^{54}$ e RICHARDSON ${ }^{99}$. Para obtenção do erro casual dos valores obtidos em tempos distintos, aplicou-se a fórmula proposta por DAHLBERG ${ }^{35}$ - $\left(\mathrm{Se}^{2}=\right.$ somatória $\left.\mathrm{d}^{2} / 2 \mathrm{n}\right)$ - onde "d" indica a diferença entre as mensurações de uma mesma variável e " $n$ " indica o número de pares de cefalogramas comparados.

\subsubsection{Testes estatísticos}

A análise estatística empregada objetivou a comparação de dois grupos aleatórios e independentes. Realizou-se inicialmente o teste de KolmogorovSmirnoff, para avaliar a distribuição dos casos nas variáveis, tendo sido observada uma distribuição normal em todas as grandezas avaliadas (tabelas 3 e 4). A partir da confirmação desta distribuição normal, denotando a possibilidade de comparação dos resultados pelo teste $t$, iniciou-se a comparação, por meio do teste $t$ independente, entre os dois grupos quanto aos valores iniciais das grandezas estudadas (T1), visando avaliar a compatibilidade dos grupos. Posteriormente, para a comparação das alterações obtidas durante o tratamento (T2-T1), entre os dois grupos, realizou-se também o teste $t$ independente. Finalmente, foi realizada uma 
análise intragrupo, para verificar as alterações entre as fases inicial e final do tratamento $(\mathrm{T} 1 \times \mathrm{T} 2)$, utilizando-se o teste $t$ pareado. Para realização dos testes estatísticos, todas as medidas foram analisadas pelo programa Statistica*. Os resultados foram considerados estatisticamente significantes para $p<0,05$.

"Statistica for Windows - release 4.3B - Copywright Statsoft, Inc. 1993. 


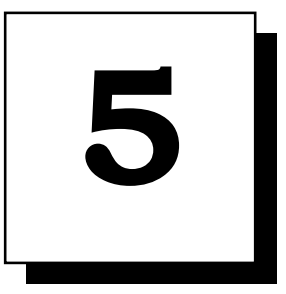

RESULTADOS 


\section{RESULTADOS}

Os resultados encontrados neste trabalho estão apresentados nas tabelas seguintes. Na tabela 2 estão demonstrados os valores dos erros casuais $^{35}$ e sistemáticos ${ }^{54}$, da avaliação intra-examinador. As tabelas 3 e 4 apresentam os resultados do teste de Kolmogorov-Smirnoff realizado para cada variável inicial (T1), final (T2) e alterações com o tratamento (T2-T1), para os grupos 1 e 2, respectivamente. Houve uma distribuição normal para todas as variáveis, permitindo portanto a utilização do teste $t$ para análise estatística dos dados. A tabela 5 apresenta os resultados da comparação dos valores iniciais entre os dois grupos estudados, realizado pelo teste $t$ pareado, fornecendo dados para a avaliação da compatibilidade inicial da amostra.

$\mathrm{Na}$ tabela 6 pode-se verificar os resultados do teste $t$ para variáveis independentes, da comparação dos grupos 1 e 2, quanto às alterações obtidas durante o período de tratamento. A tabela 7 evidencia o resultado da comparação, pelo teste $t$ pareado, entre os valores iniciais (T1) e ao final do tratamento (T2), observado para os pacientes do grupo 1, tratados com extrações de três pré-molares. Na tabela 8 , de forma semelhante à tabela anterior, porém para os pacientes do grupo 2, tratados com extrações de quatro pré-molares, verifica-se, pelo teste $t$ pareado, a comparação dos valores iniciais (T1) e ao término do tratamento (T2). 
Tabela 2 - Análise do erro intra-examinador. Apresentação dos erros casuais (Dahlberg) e sistemáticos.

\begin{tabular}{|c|c|c|c|c|c|c|c|}
\hline \multirow[t]{2}{*}{ Variáveis } & \multicolumn{2}{|c|}{$1^{\text {a }}$ Medição } & \multicolumn{2}{|c|}{$2^{a}$ Medição } & \multirow[b]{2}{*}{ Dif. } & \multirow[b]{2}{*}{ Dahlberg } & \multirow[b]{2}{*}{$\mathbf{p}$} \\
\hline & Média & D.P. & Média & D.P. & & & \\
\hline \multicolumn{8}{|c|}{ COMPONENTE MAXILAR } \\
\hline SNA & 82.96000 & 4.106418 & 82.97000 & 4.115837 & -0.010000 & 0.146628 & 0.888028 \\
\hline CO-A & 83.82000 & 4.368778 & 83.83000 & 4.383314 & -0.010000 & 0.067082 & 0.757740 \\
\hline \multicolumn{8}{|c|}{ COMPONENTE MANDIBULAR } \\
\hline SNB & 78.34000 & 3.911578 & 78.30000 & 3.856884 & 0.040000 & 0.122474 & 0.494466 \\
\hline CO-GN & 109.1200 & 4.348895 & 109.1700 & 4.415893 & -0.050000 & 0.107238 & 0.322121 \\
\hline \multicolumn{8}{|c|}{ RELAÇÃO ENTRE MAXILA E MANDÍBULA } \\
\hline ANB & 4.630000 & 1.775794 & 4.670000 & 1.782663 & -0.040000 & 0.176068 & 0.637032 \\
\hline Dif. MX-MD & 25.31000 & 2.706145 & 25.34000 & 2.674655 & -0.30000 & 0.132287 & 0.637642 \\
\hline \multicolumn{8}{|c|}{ PADRÃO DE CRESCIMENTO } \\
\hline SN.GoGN & 33.32000 & 3.545200 & 33.34000 & 3.550336 & -0.020000 & 0.094868 & 0.661780 \\
\hline FMA & 27.68000 & 4.526171 & 27.69000 & 4.470011 & -0.010000 & 0.111803 & 0.853436 \\
\hline AFAI & 66.30000 & 3.705551 & 66.33000 & 3.740484 & -0.030000 & 0.092195 & 0.496102 \\
\hline \multicolumn{8}{|c|}{ COMPONENTE DENTOALVEOLAR POSTERIOR } \\
\hline U6-PTV & 15.73000 & 3.749681 & 15.76000 & 3.754760 & -0.030000 & 0.102469 & 0.541351 \\
\hline U6-PP & 23.71000 & 2.320177 & 23.73000 & 2.367394 & -0.020000 & 0.083666 & 0.619301 \\
\hline L6-PTV & 14.61000 & 4.440083 & 14.66000 & 4.464726 & -0.050000 & 0.120415 & 0.380856 \\
\hline L6-PM & 29.87000 & 2.419848 & 29.86000 & 2.368872 & 0.010000 & 0.139642 & 0.882459 \\
\hline \multicolumn{8}{|c|}{ COMPONENTE DENTOALVEOLAR ANTERIOR SUPERIOR } \\
\hline U1.NA & 26.79000 & 12.08677 & 26.78000 & 12.13020 & 0.010000 & 0.146628 & 0.888028 \\
\hline U1-NA & 5.090000 & 3.719752 & 5.100000 & 3.653613 & -0.010000 & 0.086602 & 0.811374 \\
\hline U1.PP & 116.9600 & 12.14232 & 116.9800 & 12.14293 & -0.020000 & 0.151657 & 0.785082 \\
\hline U1-Aperp & 5.300000 & 3.384934 & 5.320000 & 3.425006 & -0.020000 & 0.118321 & 0.726314 \\
\hline U1-PP & 27.84000 & 2.362767 & 27.80000 & 2.371591 & 0.040000 & 0.148323 & 0.574356 \\
\hline \multicolumn{8}{|c|}{ COMPONENTE DENTOALVEOLAR ANTERIOR INFERIOR } \\
\hline L1.NB & 29.45000 & 4.943739 & 29.54000 & 4.899932 & -0.090000 & 0.143178 & 0.170783 \\
\hline L1-NB & 5.440000 & 1.714124 & 5.450000 & 1.757049 & -0.010000 & 0.092195 & 0.822655 \\
\hline L1.PM & 95.58000 & 4.238920 & 95.61000 & 4.333705 & -0.030000 & 0.111803 & 0.576312 \\
\hline L1-Bperp & 6.790000 & 2.080304 & 6.780000 & 2.071929 & 0.010000 & 0.150000 & 0.890531 \\
\hline L1-PM & 39.44000 & 2.834000 & 39.40000 & 2.867054 & 0.040000 & 0.154919 & 0.591051 \\
\hline \multicolumn{8}{|c|}{ COMPONENTE TEGUMENTAR } \\
\hline H.NB & 13.71000 & 1.891766 & 13.67000 & 1.855951 & 0.040000 & 0.151657 & 0.582953 \\
\hline H-Nariz & 2.220000 & 2.504130 & 2.170000 & 2.554321 & 0.050000 & 0.102469 & 0.298719 \\
\hline $\mathrm{H}-\mathrm{Li}$ & 1.500000 & 1.446067 & 1.610000 & 1.290521 & -0.110000 & 0.185741 & 0.199881 \\
\hline \multicolumn{8}{|c|}{ COMPONENTE DOS ÍNDICES DE ASSIMETRIA } \\
\hline Ass. MX & 1.980000 & 1.094227 & 1.950000 & 1.072121 & 0.030000 & 0.217944 & 0.775876 \\
\hline Ass. MD & 1.740000 & 1.213077 & 1.795000 & 1.191276 & -0.050000 & 0.182002 & 0.528111 \\
\hline Ass. U6 & 1.490000 & 1.159933 & 1.500000 & 1.127436 & -0.010000 & 0.080622 & 0.797625 \\
\hline Ass. L6 & 2.280000 & 1.129208 & 2.140000 & 1.100707 & 0.140000 & 0.178885 & 0.077393 \\
\hline
\end{tabular}


Tabela 3 - Resultado do teste Kolmogorov-Smirnoff para os valores iniciais (T1), finais (T2) e alterações (T2-T1) para o grupo 1.

\begin{tabular}{|c|c|c|c|c|c|c|}
\hline \multirow[t]{2}{*}{ Variáveis } & \multicolumn{2}{|c|}{ INICIAL } & \multicolumn{2}{|c|}{ FINAL } & \multicolumn{2}{|c|}{ DIFERENÇA } \\
\hline & d & $\mathbf{p}$ & d & $\mathbf{p}$ & d & $\mathbf{p}$ \\
\hline IDADE & 0,157 & $>0,20$ & 0,122 & $>0,20$ & 0,124 & $>0,20$ \\
\hline \multicolumn{7}{|c|}{ COMPONENTE MAXILAR } \\
\hline SNA & 0,086 & $>0,20$ & 0,102 & $>0,20$ & 0,099 & $>0,20$ \\
\hline CO-A & 0,085 & $>0,20$ & 0,153 & $>0,20$ & 0,179 & $>0,20$ \\
\hline \multicolumn{7}{|c|}{ COMPONENTE MANDIBULAR } \\
\hline SNB & 0,145 & $>0,20$ & 0,103 & $>0,20$ & 0,110 & $>0,20$ \\
\hline CO-GN & 0,073 & $>0,20$ & 0,099 & $>0,20$ & 0,178 & $>0,20$ \\
\hline \multicolumn{7}{|c|}{ RELAÇÃO ENTRE MAXILA E MANDÍBULA } \\
\hline ANB & 0,137 & $>0,20$ & 0,096 & $>0,20$ & 0,128 & $>0,20$ \\
\hline Diff. MX-MD & 0,096 & $>0,20$ & 0,110 & $>0,20$ & 0,121 & $>0,20$ \\
\hline \multicolumn{7}{|c|}{ PADRÃO DE CRESCIMENTO } \\
\hline SN.GoGN & 0,106 & $>0,20$ & 0,090 & $>0,20$ & 0,097 & $>0,20$ \\
\hline FMA & 0,072 & $>0,20$ & 0,133 & $>0,20$ & 0,146 & $>0,20$ \\
\hline AFAI & 0,100 & $>0,20$ & 0,121 & $>0,20$ & 0,089 & $>0,20$ \\
\hline \multicolumn{7}{|c|}{ COMPONENTE DENTOALVEOLAR POSTERIOR } \\
\hline U6-PTV & 0,097 & $>0,20$ & 0,064 & $>0,20$ & 0,102 & $>0,20$ \\
\hline U6-PP & 0,077 & $>0,20$ & 0,109 & $>0,20$ & 0,104 & $>0,20$ \\
\hline L6-PTV & 0,130 & $>0,20$ & 0,124 & $>0,20$ & 0,065 & $>0,20$ \\
\hline L6-PM & 0,099 & $>0,20$ & 0,070 & $>0,20$ & 0,214 & $<0,15$ \\
\hline \multicolumn{7}{|c|}{ COMPONENTE DENTOALVEOLAR ANTERIOR SUPERIOR } \\
\hline U1.NA & 0,083 & $>0,20$ & 0,104 & $>0,20$ & 0,120 & $>0,20$ \\
\hline U1-NA & 0,071 & $>0,20$ & 0,175 & $>0,20$ & 0,123 & $>0,20$ \\
\hline U1.PP & 0,082 & $>0,20$ & 0,121 & $>0,20$ & 0,114 & $>0,20$ \\
\hline U1-Aperp & 0,078 & $>0,20$ & 0,084 & $>0,20$ & 0,139 & $>0,20$ \\
\hline U1-PP & 0,088 & $>0,20$ & 0,110 & $>0,20$ & 0,172 & $>0,20$ \\
\hline \multicolumn{7}{|c|}{ COMPONENTE DENTOALVEOLAR ANTERIOR INFERIOR } \\
\hline L1.NB & 0,125 & $>0,20$ & 0,081 & $>0,20$ & 0,096 & $>0,20$ \\
\hline L1-NB & 0,160 & $>0,20$ & 0,117 & $>0,20$ & 0,169 & $>0,20$ \\
\hline L1.PM & 0,096 & $>0,20$ & 0,170 & $>0,20$ & 0,092 & $>0,20$ \\
\hline L1-Bperp & 0,082 & $>0,20$ & 0,160 & $>0,20$ & 0,135 & $>0,20$ \\
\hline L1-PM & 0,127 & $>0,20$ & 0,113 & $>0,20$ & 0,110 & $>0,20$ \\
\hline \multicolumn{7}{|c|}{ COMPONENTE TEGUMENTAR } \\
\hline H.NB & 0,086 & $>0,20$ & 0,196 & $<0,20$ & 0,112 & $>0,20$ \\
\hline H-Nariz & 0,119 & $>0,20$ & 0,138 & $>0,20$ & 0,087 & $>0,20$ \\
\hline $\mathrm{H}-\mathrm{Li}$ & 0,124 & $>0,20$ & 0,093 & $>0,20$ & 0,113 & $>0,20$ \\
\hline \multicolumn{7}{|c|}{ COMPONENTE DOS ÍNDICES DE ASSIMETRIA } \\
\hline Ass. MX & 0,111 & $>0,20$ & 0,100 & $>0,20$ & 0,077 & $>0,20$ \\
\hline Ass. MD & 0,113 & $>0,20$ & 0,115 & $>0,20$ & 0,161 & $>0,20$ \\
\hline Ass. U6 & 0,131 & $>0,20$ & 0,142 & $>0,20$ & 0,220 & $<0,10$ \\
\hline Ass. L6 & 0,111 & $>0,20$ & 0,128 & $>0,20$ & 0,135 & $>0,20$ \\
\hline
\end{tabular}


Tabela 4 - Resultado do teste Kolmogorov-Smirnoff para os valores iniciais (T1), finais (T2) e alterações (T2-T1) para o grupo 2.

\begin{tabular}{|c|c|c|c|c|c|c|}
\hline \multirow[t]{2}{*}{ Variáveis } & \multicolumn{2}{|c|}{ INICIAL } & \multicolumn{2}{|c|}{ FINAL } & \multicolumn{2}{|c|}{ DIFERENÇA } \\
\hline & d & $\mathbf{p}$ & d & $\mathbf{p}$ & $\mathbf{p}$ & d \\
\hline IDADE & 0,108 & $>0,20$ & 0,136 & $>0,20$ & 0,154 & $>0,20$ \\
\hline \multicolumn{7}{|c|}{ COMPONENTE MAXILAR } \\
\hline SNA & 0,095 & $>0,20$ & 0,121 & $>0,20$ & 0,086 & $>0,20$ \\
\hline CO-A & 0,127 & $>0,20$ & 0,088 & $>0,20$ & 0,088 & $>0,20$ \\
\hline \multicolumn{7}{|c|}{ COMPONENTE MANDIBULAR } \\
\hline SNB & 0,119 & $>0,20$ & 0,124 & $>0,20$ & 0,103 & $>0,20$ \\
\hline CO-GN & 0,088 & $>0,20$ & 0,121 & $>0,20$ & 0,092 & $>0,20$ \\
\hline \multicolumn{7}{|c|}{ RELAÇÃO ENTRE MAXILA E MANDÍBULA } \\
\hline ANB & 0,120 & $>0,20$ & 0,104 & $>0,20$ & 0,083 & $>0,20$ \\
\hline Diff. MX-MD & 0,146 & $>0,20$ & 0,120 & $>0,20$ & 0,124 & $>0,20$ \\
\hline \multicolumn{7}{|c|}{ PADRÃO DE CRESCIMENTO } \\
\hline SN.GoGN & 0,095 & $>0,20$ & 0,066 & $>0,20$ & 0,073 & $>0,20$ \\
\hline FMA & 0,117 & $>0,20$ & 0,116 & $>0,20$ & 0,093 & $>0,20$ \\
\hline AFAI & 0,116 & $>0,20$ & 0,091 & $>0,20$ & 0,116 & $>0,20$ \\
\hline \multicolumn{7}{|c|}{ COMPONENTE DENTOALVEOLAR POSTERIOR } \\
\hline U6-PTV & 0,072 & $>0,20$ & 0,129 & $>0,20$ & 0,126 & $>0,20$ \\
\hline U6-PP & 0,106 & $>0,20$ & 0,119 & $>0,20$ & 0,107 & $>0,20$ \\
\hline L6-PTV & 0,118 & $>0,20$ & 0,146 & $>0,20$ & 0,136 & $>0,20$ \\
\hline L6-PM & 0,111 & $>0,20$ & 0,113 & $>0,20$ & 0,127 & $>0,20$ \\
\hline \multicolumn{7}{|c|}{ COMPONENTE DENTOALVEOLAR ANTERIOR SUPERIOR } \\
\hline U1.NA & 0,109 & $>0,20$ & 0,095 & $>0,20$ & 0,108 & $>0,20$ \\
\hline U1-NA & 0,132 & $>0,20$ & 0,082 & $>0,20$ & 0,055 & $>0,20$ \\
\hline U1.PP & 0,134 & $>0,20$ & 0,127 & $>0,20$ & 0,077 & $>0,20$ \\
\hline U1-Aperp & 0,100 & $>0,20$ & 0,098 & $>0,20$ & 0,078 & $>0,20$ \\
\hline U1-PP & 0,150 & $>0,20$ & 0,070 & $>0,20$ & 0,172 & $>0,20$ \\
\hline \multicolumn{7}{|c|}{ COMPONENTE DENTOALVEOLAR ANTERIOR INFERIOR } \\
\hline L1.NB & 0,129 & $>0,20$ & 0,127 & $>0,20$ & 0,117 & $>0,20$ \\
\hline L1-NB & 0,149 & $>0,20$ & 0,102 & $>0,20$ & 0,101 & $>0,20$ \\
\hline L1.PM & 0,073 & $>0,20$ & 0,143 & $>0,20$ & 0,098 & $>0,20$ \\
\hline L1-Bperp & 0,088 & $>0,20$ & 0,126 & $>0,20$ & 0,131 & $>0,20$ \\
\hline L1-PM & 0,154 & $>0,20$ & 0,094 & $>0,20$ & 0,201 & $<0,15$ \\
\hline \multicolumn{7}{|c|}{ COMPONENTE TEGUMENTAR } \\
\hline H.NB & 0,163 & $>0,20$ & 0,120 & $>0,20$ & 0,128 & $>0,20$ \\
\hline H-Nariz & 0,073 & $>0,20$ & 0,114 & $>0,20$ & 0,202 & $<0,15$ \\
\hline $\mathrm{H}-\mathrm{Li}$ & 0,137 & $>0,20$ & 0,128 & $>0,20$ & 0,132 & $>0,20$ \\
\hline \multicolumn{7}{|c|}{ COMPONENTE DOS ÍNDICES DE ASSIMETRIA } \\
\hline Ass. MX & 0,186 & $>0,20$ & 0,143 & $>0,20$ & 0,109 & $>0,20$ \\
\hline Ass. MD & 0,127 & $>0,20$ & 0,154 & $>0,20$ & 0,175 & $>0,20$ \\
\hline Ass. U6 & 0,120 & $>0,20$ & 0,125 & $>0,20$ & 0,080 & $>0,20$ \\
\hline Ass. L6 & 0,196 & $<0,20$ & 0,148 & $>0,20$ & 0,121 & $>0,20$ \\
\hline
\end{tabular}


Tabela 5 - Resultado do teste $t$ pareado entre as variáveis iniciais dos grupos 1 e 2 (compatibilidade da amostra).

\begin{tabular}{|c|c|c|c|c|c|c|}
\hline \multirow[t]{2}{*}{ Variáveis } & \multicolumn{2}{|c|}{ GRUPO 1} & \multicolumn{2}{|c|}{ GRUPO 2} & \multirow[b]{2}{*}{ t-value } & \multirow[b]{2}{*}{$\mathbf{P}$} \\
\hline & Média & D.P. & Média & D.P. & & \\
\hline IDADE & 14.2838 & 1.73630 & 13.1548 & 1.487701 & 2.65896 & .010201 \\
\hline \multicolumn{7}{|c|}{ COMPONENTE MAXILAR } \\
\hline SNA & 81.9724 & 3.59025 & 82.4931 & 3.277077 & -.57684 & .566361 \\
\hline CO-A & 84.0483 & 4.27648 & 84.0138 & 5.084200 & .02795 & .977801 \\
\hline \multicolumn{7}{|c|}{ COMPONENTE MANDIBULAR } \\
\hline SNB & 77.3793 & 3.73003 & 77.5483 & 2.621562 & -.19958 & .842533 \\
\hline CO-GN & 109.3586 & 5.37325 & 107.8345 & 6.265682 & .99438 & .324315 \\
\hline \multicolumn{7}{|c|}{ RELAÇÃO ENTRE MAXILA E MANDÍBULA } \\
\hline ANB & 4.5931 & 2.65827 & 4.9310 & 2.178319 & -.52951 & .598544 \\
\hline Diff. MX-MD & 25.3172 & 4.55444 & 23.8241 & 4.083386 & 1.31448 & .194042 \\
\hline \multicolumn{7}{|c|}{ PADRÃO DE CRESCIMENTO } \\
\hline SN.GoGN & 33.1207 & 4.28414 & 34.0897 & 5.076722 & -.78552 & .435462 \\
\hline FMA & 26.3552 & 4.88091 & 27.1414 & 4.969875 & -.60780 & .545776 \\
\hline AFAI & 65.5724 & 5.30006 & 64.9724 & 5.608596 & .41872 & .677025 \\
\hline \multicolumn{7}{|c|}{ COMPONENTE DENTOALVEOLAR POSTERIOR } \\
\hline U6-PTV & 15.9517 & 3.66115 & 15.9034 & 2.948787 & .05530 & .956095 \\
\hline U6-PP & 23.7897 & 2.66516 & 22.9414 & 2.662104 & 1.21268 & .230343 \\
\hline L6-PTV & 14.7138 & 3.93008 & 14.8724 & 2.819561 & -.17660 & .860459 \\
\hline L6-PM & 29.8931 & 2.67367 & 29.2414 & 2.033912 & 1.04473 & .300635 \\
\hline \multicolumn{7}{|c|}{ COMPONENTE DENTOALVEOLAR ANTERIOR SUPERIOR } \\
\hline U1.NA & 25.7172 & 9.23023 & 25.4897 & 6.074087 & .11092 & .912078 \\
\hline U1-NA & 5.2552 & 3.07972 & 5.0103 & 2.994441 & .30693 & .760032 \\
\hline U1.PP & 115.9552 & 9.63563 & 115.5448 & 5.760059 & .19684 & .844662 \\
\hline U1-Aperp & 5.3621 & 3.08631 & 5.4172 & 3.211483 & -.06671 & .947054 \\
\hline $\mathrm{U} 1-\mathrm{PP}$ & 27.7862 & 2.44507 & 27.6379 & 2.628336 & .22243 & .824785 \\
\hline \multicolumn{7}{|c|}{ COMPONENTE DENTOALVEOLAR ANTERIOR INFERIOR } \\
\hline L1.NB & 29.8862 & 6.11542 & 30.1138 & 6.159993 & -.14120 & .888222 \\
\hline L1-NB & 6.0034 & 2.09122 & 6.1931 & 2.395670 & -.32117 & .749277 \\
\hline L1.PM & 97.1966 & 6.51857 & 96.0034 & 6.994768 & .67199 & .504356 \\
\hline L1-Bperp & 7.4655 & 2.37461 & 7.4552 & 2.571351 & .01592 & .987358 \\
\hline L1-PM & 39.4138 & 2.83923 & 39.4414 & 3.156910 & -.03499 & .972213 \\
\hline \multicolumn{7}{|c|}{ COMPONENTE TEGUMENTAR } \\
\hline H.NB & 14.2586 & 4.49313 & 15.1655 & 3.914376 & -.81955 & .415945 \\
\hline H-Nariz & 1.7690 & 3.84941 & .7379 & 3.751991 & 1.03290 & .306091 \\
\hline $\mathrm{H}-\mathrm{Li}$ & 1.6724 & 1.73141 & 2.2138 & 1.665988 & -1.21336 & .230086 \\
\hline \multicolumn{7}{|c|}{ COMPONENTE DOS ÍNDICES DE ASSIMETRIA } \\
\hline Ass. MX & 2.1241 & 1.31629 & 2.0948 & 1.684612 & .07383 & .941408 \\
\hline Ass. MD & 1.5759 & 1.13662 & 1.5172 & 1.001252 & .20841 & .835666 \\
\hline Ass. U6 & 1.9793 & 1.37850 & 1.8172 & .811994 & .54552 & .587561 \\
\hline Ass. L6 & 2.0724 & 1.11224 & 2.0138 & 1.166412 & .19587 & .845422 \\
\hline
\end{tabular}


Tabela 6 - Resultado do teste $t$ independente entre as alterações ocorridas nos pacientes dos grupos 1 e 2 durante o tratamento.

\begin{tabular}{|c|c|c|c|c|c|c|}
\hline \multirow[t]{2}{*}{ Variáveis } & \multicolumn{2}{|c|}{ GRUPO 1} & \multicolumn{2}{|c|}{ GRUPO 2} & \multirow[b]{2}{*}{ t-value } & \multirow[b]{2}{*}{$\mathbf{p}$} \\
\hline & Média & D.P. & Média & D.P. & & \\
\hline IDADE & 2.6193 & .81075 & 2.4866 & .565157 & .72340 & .472448 \\
\hline \multicolumn{7}{|c|}{ COMPONENTE MAXILAR } \\
\hline SNA & -.3724 & 1.82950 & -.7759 & 1.550727 & .90591 & .368866 \\
\hline CO-A & 1.0310 & 2.59561 & -.1414 & 2.754285 & 1.66824 & .100851 \\
\hline \multicolumn{7}{|c|}{ COMPONENTE MANDIBULAR } \\
\hline SNB & .4793 & 1.98267 & .8414 & 1.333502 & -.81602 & .417945 \\
\hline CO-GN & 3.8793 & 4.21243 & 3.8414 & 3.822351 & .03591 & .971481 \\
\hline \multicolumn{7}{|c|}{ RELAÇÃO ENTRE MAXILA E MANDÍBULA } \\
\hline ANB & -.8448 & 1.50963 & -1.6069 & 1.182591 & 2.14001 & .036724 \\
\hline Diff. MX-MD & 2.8483 & 2.86738 & 3.9793 & 2.606363 & -1.57185 & .121618 \\
\hline \multicolumn{7}{|c|}{ PADRÃO DE CRESCIMENTO } \\
\hline SN.GoGN & -.8345 & 2.32014 & -.7621 & 2.087106 & -.12496 & .901005 \\
\hline FMA & -1.2310 & 2.21957 & -.5379 & 3.116135 & -.97561 & .333456 \\
\hline AFAI & 2.4276 & 2.36657 & 2.1724 & 2.549075 & .39506 & .694296 \\
\hline \multicolumn{7}{|c|}{ COMPONENTE DENTOALVEOLAR POSTERIOR } \\
\hline U6-PTV & 3.8966 & 4.00147 & 2.6724 & 3.231861 & 1.28163 & .205255 \\
\hline U6-PP & 1.6034 & 1.86116 & 1.6517 & 1.312201 & -.11416 & .909518 \\
\hline L6-PTV & 3.6000 & 4.32955 & 4.4241 & 3.147182 & -.82916 & .410534 \\
\hline L6-PM & 2.3690 & 1.66564 & 2.6379 & 1.558941 & -.63489 & .528085 \\
\hline \multicolumn{7}{|c|}{ COMPONENTE DENTOALVEOLAR ANTERIOR SUPERIOR } \\
\hline U1.NA & -2.4897 & 10.70939 & -4.4828 & 7.741727 & .81222 & .420103 \\
\hline U1-NA & -2.0828 & 3.06047 & -2.3379 & 2.641755 & .33989 & .735213 \\
\hline U1.PP & -2.2414 & 10.94690 & -5.3379 & 8.113235 & 1.22382 & .226143 \\
\hline U1-Aperp & -1.9828 & 2.93198 & -2.7931 & 3.074658 & 1.02714 & .308770 \\
\hline $\mathrm{U} 1-\mathrm{PP}$ & .3034 & 2.46641 & .6172 & 1.584764 & -.57640 & .566651 \\
\hline \multicolumn{7}{|c|}{ COMPONENTE DENTOALVEOLAR ANTERIOR INFERIOR } \\
\hline L1.NB & -1.8862 & 4.36363 & -4.3793 & 6.312085 & 1.74961 & .085663 \\
\hline L1-NB & -.4414 & 1.17611 & -2.0931 & 1.629840 & 4.42555 & .000045 \\
\hline L1.PM & -1.7965 & 4.93923 & -4.3241 & 6.343875 & 1.69297 & .096016 \\
\hline L1-Bperp & -.8138 & 1.32334 & -2.2966 & 1.767864 & 3.61586 & .000643 \\
\hline L1-PM & 1.1897 & 1.60453 & -.3724 & 1.957202 & 3.32379 & .001570 \\
\hline \multicolumn{7}{|c|}{ COMPONENTE TEGUMENTAR } \\
\hline H.NB & -2.3552 & 2.39800 & -3.9379 & 2.182628 & 2.62860 & .011045 \\
\hline H-Nariz & 3.1207 & 2.71851 & 4.6069 & 2.395968 & -2.20867 & .031307 \\
\hline $\mathrm{H}-\mathrm{Li}$ & -.2586 & 1.06922 & -.8828 & 1.498587 & 1.82576 & .073220 \\
\hline \multicolumn{7}{|c|}{ COMPONENTE DOS ÍNDICES DE ASSIMETRIA } \\
\hline Ass. MX & .3621 & 1.18620 & .0724 & 1.463337 & .82806 & .411152 \\
\hline Ass. MD & .1569 & 1.13955 & .0483 & 1.283792 & .34076 & .734562 \\
\hline Ass. U6 & -.0724 & .94789 & -.3414 & 1.388092 & .86172 & .392519 \\
\hline Ass. L6 & 1.4276 & 1.67394 & -.5034 & 1.522095 & 4.59624 & .000025 \\
\hline
\end{tabular}


Tabela 7 - Alterações ocorridas com o tratamento no grupo 1.

\begin{tabular}{|c|c|c|c|c|c|c|c|}
\hline \multirow[t]{2}{*}{ Variáveis } & \multicolumn{2}{|c|}{ INICIAL } & \multicolumn{2}{|c|}{ FINAL } & \multirow[b]{2}{*}{ Dif. } & \multirow[b]{2}{*}{$\mathbf{t}$} & \multirow[b]{2}{*}{$\mathbf{p}$} \\
\hline & Média & D.P. & Média & D.P. & & & \\
\hline IDADE & 14.28379 & 1.736300 & 16.90310 & 1.901687 & -2.61931 & -17.3979 & .000000 \\
\hline \multicolumn{8}{|c|}{ COMPONENTE MAXILAR } \\
\hline SNA & 81.97241 & 3.590254 & 81.60000 & 3.744234 & .372414 & 1.096207 & .282328 \\
\hline CO-A & 84.04828 & 4.276482 & 85.07931 & 5.350659 & -1.03103 & -2.13910 & .041288 \\
\hline \multicolumn{8}{|c|}{ COMPONENTE MANDIBULAR } \\
\hline SNB & 77.37931 & 3.730031 & 77.85862 & 3.390482 & -.479310 & -1.30186 & .203572 \\
\hline CO-GN & 109.3586 & 5.373248 & 113.2379 & 6.910779 & -3.87931 & -4.95931 & .000031 \\
\hline \multicolumn{8}{|c|}{ RELAÇÃO ENTRE MAXILA E MANDÍBULA } \\
\hline ANB & 4.593103 & 2.658266 & 3.748276 & 2.078224 & .844828 & 3.013671 & .005430 \\
\hline Dif. MX-MD & 25.31724 & 4.554438 & 28.16552 & 4.515313 & -2.84828 & -5.34928 & .000011 \\
\hline \multicolumn{8}{|c|}{ PADRÃO DE CRESCIMENTO } \\
\hline SN.GoGN & 33.12069 & 4.284138 & 32.28621 & 4.879822 & .834483 & 1.936877 & .062910 \\
\hline FMA & 26.35517 & 4.880909 & 25.12414 & 5.450665 & 1.231034 & 2.986757 & .005804 \\
\hline AFAI & 65.57241 & 5.300060 & 68.00000 & 5.867647 & -2.42759 & -5.52401 & .000007 \\
\hline \multicolumn{8}{|c|}{ COMPONENTE DENTOALVEOLAR POSTERIOR } \\
\hline U6-PTV & 15.95172 & 3.661149 & 19.84828 & 4.838508 & -3.89655 & -5.24396 & .000014 \\
\hline U6-PP & 23.78966 & 2.665165 & 25.39310 & 2.763658 & -1.60345 & -4.63949 & .000074 \\
\hline L6-PTV & 14.71379 & 3.930079 & 18.31379 & 4.971398 & -3.60000 & -4.47774 & .000115 \\
\hline L6-PM & 29.89310 & 2.673672 & 32.26207 & 2.731093 & -2.36897 & -7.65908 & .000000 \\
\hline \multicolumn{8}{|c|}{ COMPONENTE DENTOALVEOLAR ANTERIOR SUPERIOR } \\
\hline U1.NA & 25.71724 & 9.230233 & 23.22759 & 7.262029 & 2.489655 & 1.251911 & .220960 \\
\hline U1-NA & 5.255172 & 3.079725 & 3.172414 & 2.087530 & 2.082759 & 3.664796 & .001024 \\
\hline U1.PP & 115.9552 & 9.635633 & 113.7138 & 7.235464 & 2.241379 & 1.102613 & .279583 \\
\hline U1-Aperp & 5.362069 & 3.086308 & 3.379310 & 2.217846 & 1.982759 & 3.641737 & .001088 \\
\hline U1-PP & 27.78621 & 2.445071 & 28.08966 & 3.389305 & -.303448 & -.662548 & .513037 \\
\hline \multicolumn{8}{|c|}{ COMPONENTE DENTOALVEOLAR ANTERIOR INFERIOR } \\
\hline L1.NB & 29.88621 & 6.115421 & 28.00000 & 5.457629 & 1.886207 & 2.327774 & .027375 \\
\hline L1-NB & 6.003448 & 2.091220 & 5.562069 & 2.040731 & .441379 & 2.020991 & .052936 \\
\hline L1.PM & 97.19655 & 6.518571 & 95.40000 & 7.144578 & 1.796552 & 1.958749 & .060170 \\
\hline L1-Bperp & 7.465517 & 2.374609 & 6.651724 & 2.164918 & .813793 & 3.311626 & .002563 \\
\hline L1-PM & 39.41379 & 2.839231 & 40.60345 & 2.814438 & -1.18966 & -3.99274 & .000428 \\
\hline \multicolumn{8}{|c|}{ COMPONENTE TEGUMENTAR } \\
\hline H.NB & 14.25862 & 4.493131 & 11.90345 & 4.245374 & 2.355172 & 5.288981 & .000013 \\
\hline H-Nariz & 1.768966 & 3.849407 & 4.889655 & 3.619426 & -3.12069 & -6.18186 & .000001 \\
\hline $\mathrm{H}-\mathrm{Li}$ & 1.672414 & 1.731411 & 1.413793 & 1.773561 & .258621 & 1.302555 & .203339 \\
\hline \multicolumn{8}{|c|}{ COMPONENTE DOS ÍNDICES DE ASSIMETRIA } \\
\hline Ass. MX & 2.124138 & 1.316287 & 2.486207 & 1.473510 & -.362069 & -1.64373 & .111415 \\
\hline Ass. MD & 1.575862 & 1.136616 & 1.732759 & 1.154303 & -.156897 & -.741447 & .464596 \\
\hline Ass. U6 & 1.979310 & 1.378503 & 1.906897 & 1.404821 & .072414 & .411398 & .683913 \\
\hline Ass. L6 & 2.072414 & 1.112236 & 3.500000 & 1.764936 & -1.42759 & -4.59264 & .000084 \\
\hline
\end{tabular}


Tabela 8 - Alterações ocorridas com o tratamento no grupo 2.

\begin{tabular}{|c|c|c|c|c|c|c|c|}
\hline \multirow[t]{2}{*}{ Variáveis } & \multicolumn{2}{|c|}{ INICIAL } & \multicolumn{2}{|c|}{ FINAL } & \multirow[b]{2}{*}{ Dif. } & \multirow[b]{2}{*}{$\mathbf{t}$} & \multirow[b]{2}{*}{$\mathbf{p}$} \\
\hline & Média & D.P. & Média & D.P. & & & \\
\hline IDADE & 13.15483 & 1.487701 & 15.64138 & 1.329306 & -2.48655 & -23.6934 & .000000 \\
\hline \multicolumn{8}{|c|}{ COMPONENTE MAXILAR } \\
\hline SNA & 82.49310 & 3.277077 & 81.71724 & 4.078258 & .775862 & 2.694314 & .011786 \\
\hline CO-A & 84.01379 & 5.084200 & 83.87241 & 4.339675 & .141379 & .276424 & .784253 \\
\hline \multicolumn{8}{|c|}{ COMPONENTE MANDIBULAR } \\
\hline SNB & 77.54828 & 2.621562 & 78.38966 & 3.034956 & -.841379 & -3.39780 & .002054 \\
\hline CO-GN & 107.8345 & 6.265682 & 111.6759 & 7.445452 & -3.84138 & -5.41197 & .000009 \\
\hline \multicolumn{8}{|c|}{ RELAÇÃO ENTRE MAXILA E MANDÍBULA } \\
\hline ANB & 4.931034 & 2.178319 & 3.324138 & 2.449877 & 1.606897 & 7.317323 & .000000 \\
\hline Dif. MX-MD & 23.82414 & 4.083386 & 27.80345 & 5.084956 & -3.97931 & -8.22189 & .000000 \\
\hline \multicolumn{8}{|c|}{ PADRÃO DE CRESCIMENTO } \\
\hline SN.GoGN & 34.08966 & 5.076722 & 33.32759 & 5.638762 & .762069 & 1.966296 & .059249 \\
\hline FMA & 27.14138 & 4.969875 & 26.60345 & 4.965918 & .537931 & .929628 & .360509 \\
\hline AFAI & 64.97241 & 5.608596 & 67.14483 & 6.054077 & -2.17241 & -4.58943 & .000085 \\
\hline \multicolumn{8}{|c|}{ COMPONENTE DENTOALVEOLAR POSTERIOR } \\
\hline U6-PTV & 15.90345 & 2.948787 & 18.57586 & 3.018710 & -2.67241 & -4.45297 & .000123 \\
\hline U6-PP & 22.94138 & 2.662104 & 24.59310 & 2.816270 & -1.65172 & -6.77854 & .000000 \\
\hline L6-PTV & 14.87241 & 2.819561 & 19.29655 & 3.248679 & -4.42414 & -7.57017 & .000000 \\
\hline L6-PM & 29.24138 & 2.033912 & 31.87931 & 2.453042 & -2.63793 & -9.11240 & .000000 \\
\hline \multicolumn{8}{|c|}{ COMPONENTE DENTOALVEOLAR ANTERIOR SUPERIOR } \\
\hline U1.NA & 25.48966 & 6.074087 & 21.00690 & 6.155017 & 4.482759 & 3.118218 & .004184 \\
\hline U1-NA & 5.010345 & 2.994441 & 2.672414 & 2.712260 & 2.337931 & 4.765827 & .000053 \\
\hline U1.PP & 115.5448 & 5.760059 & 110.2069 & 6.389273 & 5.337931 & 3.543055 & .001409 \\
\hline U1-Aperp & 5.417241 & 3.211483 & 2.624138 & 2.546378 & 2.793103 & 4.892031 & .000037 \\
\hline U1-PP & 27.63793 & 2.628336 & 28.25517 & 3.233705 & -.617241 & -2.09744 & .045107 \\
\hline \multicolumn{8}{|c|}{ COMPONENTE DENTOALVEOLAR ANTERIOR INFERIOR } \\
\hline 1.NB & 30.11379 & 6.159993 & 25.73448 & 5.492545 & 4.379310 & 3.736215 & .000848 \\
\hline $1-\mathrm{NB}$ & 6.193103 & 2.395670 & 4.100000 & 2.167784 & 2.093103 & 6.915835 & .000000 \\
\hline 1.PM & 96.00345 & 6.994768 & 91.67931 & 6.195297 & 4.324138 & 3.670658 & .001009 \\
\hline 1-Bperp & 7.455172 & 2.571351 & 5.158621 & 2.788307 & 2.296552 & 6.995621 & .000000 \\
\hline 1-PM & 39.44138 & 3.156910 & 39.06897 & 3.425962 & .372414 & 1.024682 & .314285 \\
\hline \multicolumn{8}{|c|}{ COMPONENTE TEGUMENTAR } \\
\hline H.NB & 15.16552 & 3.914376 & 11.22759 & 4.738060 & 3.937931 & 9.715995 & .000000 \\
\hline H-Nariz & .737931 & 3.751991 & 5.344828 & 4.287656 & -4.60690 & -10.3544 & .000000 \\
\hline $\mathrm{H}-\mathrm{Li}$ & 2.213793 & 1.665988 & 1.331034 & 1.748898 & .882759 & 3.172188 & .003653 \\
\hline \multicolumn{8}{|c|}{ COMPONENTE DOS ÍNDICES DE ASSIMETRIA } \\
\hline Ass. MX & 2.094828 & 1.684612 & 2.167241 & 1.354772 & -.072414 & -.266487 & .791817 \\
\hline Ass. MD & 1.517241 & \begin{tabular}{|l|}
1.001252 \\
\end{tabular} & 1.565517 & 1.047710 & -.048276 & -.202504 & .840987 \\
\hline Ass. U6 & 1.817241 & .811994 & 1.475862 & 1.148805 & .341379 & 1.324397 & .196081 \\
\hline Ass. L6 & 2.013793 & 1.166412 & 1.510345 & 1.149641 & .503448 & 1.781198 & .085732 \\
\hline
\end{tabular}




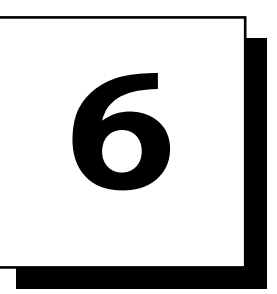

DISCUSSÃO 


\section{DISCUSSÃO}

Com o objetivo de facilitar a abordagem e interpretação dos resultados obtidos neste trabalho, serão primeiramente discutidos aspectos pertinentes à amostra e metodologia utilizadas. Em seguida, serão realizadas considerações sobre a compatibilidade inicial dos grupos avaliados e sobre a comparação das alterações cefalométricas obtidas com os dois protocolos de tratamento. Finalmente serão observadas as implicações clínicas relativas aos resultados encontrados nesta pesquisa.

\subsection{Seleção da Amostra}

Os critérios adotados para a seleção da amostra estão previamente citados no capítulo de Material e Métodos. A verificação do cumprimento destes critérios foi realizada pelo investigador, por meio do exame da documentação ortodôntica completa de cada paciente. Como regra inicial, todos os pacientes pertencentes aos grupos estudados deveriam possuir, no começo do tratamento, todos os dentes permanentes superiores e inferiores até os primeiros molares ${ }^{3,34,57,79,101,111,137}$ A opção por este procedimento foi realizada, pois já se demonstrou que a ausência de dentes durante o desenvolvimento pode proporcionar assimetrias esqueléticas ${ }^{14,102,105,125,143}$ e remodelação condilar ${ }^{67,83}$. Desta forma, procurou-se eliminar a possibilidade de ocorrência de movimentação dentária prévia, ocasionando um desarranjo do relacionamento dentário, que interferisse nas possíveis assimetrias dentárias ${ }^{57,63,103}$. 
Considerando que a má oclusão de Classe II, subdivisão, é caracterizada por uma relação assimétrica entre os primeiros molares superiores e inferiores, onde em um dos lados existe uma relação molar de Classe I, enquanto no lado oposto forma-se uma intercuspidação dos primeiros molares permanentes em Classe II; procurou-se selecionar dois grupos de pacientes que apresentassem características dentárias desta má oclusão bem definidas. Desta forma os pacientes deveriam apresentar uma má oclusão de Classe II, subdivisão completa, onde os molares relacionados em Classe II apresentassem uma intercuspidação da cúspide mésio-vestibular do primeiro molar superior ocluindo na ameia entre o primeiro molar e o segundo pré-molar inferior. Casos com relação de Classe II incompleta não foram incluídos, pois poderiam atenuar as características reais da má oclusão de Classe II, subdivisão ${ }^{80}$.

Entre os requisitos para seleção dos pacientes da amostra incluiu-se a ausência de histórico de trauma facial que poderia ter alterado o crescimento das bases apicais ${ }^{57,79,97,101}$, pois já foi demonstrado que as respostas compensatórias a esta injúria podem levar a um desequilíbrio no crescimento do côndilo e do ramo como um todo ${ }^{9,39,40}$, sendo que SKOLNICK et al. ${ }^{120}$ já constataram uma associação entre o trauma e a assimetria mandibular.

Os dois grupos pertencentes ao estudo apresentaram distribuição semelhante quanto ao gênero, de forma que esta variável não tivesse uma participação significante nos resultados obtidos. De qualquer modo, as assimetrias não apresentam diferenças estatisticamente significantes entre os gêneros, segundo trabalhos radiográficos ${ }^{7,30,82}$, anatômicos ${ }^{94}$ e clínicos ${ }^{113}$.

Todos os pacientes foram tratados com aparelhos ortodônticos corretivos fixos superior e inferior. A maior parte destes receberam tratamento 
pela técnica de Edgewise, entretanto os casos tratados mais recentes receberam aparelhos ortodônticos pré-ajustados. Além de uma distribuição semelhante entre os grupos, quanto ao tipo de aparelho empregado, este fator não interfere nos resultados encontrados, uma vez que as mecânicas ortodônticas para ambos sistemas são semelhantes para as duas abordagens de tratamento da Classe II subdivisão.

Portanto, havendo critérios rígidos para a seleção da amostra, o número de pacientes limitou-se a 29 em cada grupo, os quais foram selecionados entre todo o acervo da Disciplina de Ortodontia da Faculdade de Odontologia de Bauru, que conta com cerca de 4000 pacientes tratados. Apesar da quantidade de pacientes ser considerada ligeiramente inferior ao ideal de 30 , a diferença de apenas um indivíduo por grupo não compromete de maneira nenhuma qualquer dos dados estatísticos. A razão para este número aquém uma unidade do ideal deve-se a maior dificuldade em se encontrar casos tratados com extrações assimétricas de três pré-molares, fato provavelmente relacionado a este protocolo de extração ter tido sua aplicação generalizada mais recentemente.

\subsection{Metodologia}

O material de estudo consistiu de duas telerradiografias em norma lateral para cada paciente estudado, as quais foram realizadas no início do tratamento (T1) e imediatamente após a conclusão do tratamento (T2). A análise das alterações dentárias, esqueléticas e tegumentares ocorridas no período estudado, por meio de cefalometria radiográfica sobre estas telerradiografias é amplamente utilizada na literatura ${ }^{3,20,36,89,132}$. De qualquer forma, a mensuração de medidas na telerradiografia pode apresentar erros e 
conseqüentes resultados equivocados. Por este motivo, procurou-se minimizar todas as variáveis que pudessem influir nos resultados obtidos com a realização dos testes para verificar o erro intra-examinador.

\subsubsection{Magnificação das Imagens Radiográficas}

As telerradiografias que formam a amostra deste estudo foram obtidas em locais diferentes e por aparelhos distintos, pois para que houvesse um número de pacientes suficientes em cada grupo, necessitou-se verificar as documentações ortodônticas de todos os pacientes já tratados na instituição. Desta maneira, foram verificadas as documentações dos pacientes que efetuaram tratamento ortodôntico corretivo ao longo de mais de 29 anos, o que torna bastante aceitável que estas tenham sido realizadas em diferentes centros de documentações da cidade, em esporádicos períodos em que aparelho de Rx da Faculdade esteve impossibilitado de ser utilizado. Soma-se ao fato que em meados de 1995, a Faculdade adquiriu um novo aparelho de $\mathrm{Rx}$, em função da depreciação do anterior, também implicando na alteração da magnificação da imagem radiográfica.

Devido à diversidade de aparelhos de Rx utilizados na obtenção das telerradiografias aqui estudadas, tornou-se imprescindível realizar a correção do fator de magnificação das imagens, permitindo a comparação das medições cefalométricas tanto angulares como lineares. Por este motivo, informou-se ao programa cefalométrico informatizado o valor de magnificação de cada imagem radiográfica em função do aparelho de Rx utilizado, possibilitando a correção digital automática desta variação ${ }^{36,132}$. 


\subsubsection{Mensuração das Grandezas Cefalométricas}

O desenvolvimento da informática possibilitou que a ciência e a tecnologia pudessem evoluir nos mais diversos campos de atuação. Neste trabalho aproveitou-se deste recurso da informática, recorrendo-se a um microcomputador na medição das grandezas cefalométricas, pois este método permite trabalhar com um maior número de dados em menor período de tempo ${ }^{18,23,34,57,132}$. O programa Dentofacial Planner 7.0, disponível na Disciplina de Ortodontia, proporcionou a medição com uma precisão de $0,1 \mathrm{~mm}$ ou $0,1 \mathrm{grau}$, tendo sido já utilizado em diversos trabalhos e assegurando sua eficiência ${ }^{15,20,28,34,36,57,64,76,87-89,93,123,132,133}$. Um procedimento que apresenta o potencial de aumentar os erros durante a manipulação dos dados consiste na digitação dos valores que foram obtidos e anotados manualmente, no método convencional, para o programa de estatística. Com o método computadorizado aqui utilizado, este procedimento é eliminado, garantindo uma maior precisão na transferência de dados de um programa para o outro. Deste modo, a utilização do método computadorizado de mensuração das grandezas cefalométricas facilitou o trabalho, além de diminuir a possibilidade de erros na transferência destes dados ${ }^{99}$.

\subsubsection{Medição dos Índices de Assimetrias}

Grande parte dos estudos sobre as más oclusões assimétricas costuma utilizar os modelos de gesso para realizar as medições, mesmo que também possa ser observado um certo grau de assimetria em modelos pertencentes a indivíduos com oclusão normal ${ }^{3,45,55}$. Outras pesquisas são realizadas em dados coletados de telerradiografias póstero-anteriores e/ou radiografias submentonianas, sendo estas metodologias amplamente aceitas e utilizadas 
para avaliação de más oclusões assimétricas, como particularmente as de Classe II, subdivisão $0^{3,34,57,141}$. Entretanto convém aqui ressaltar que estas radiografias muitas vezes não fazem parte da documentação ortodôntica básica utilizada para diagnóstico e planejamento dos casos clínicos tratados rotineiramente na clínica. Nesta pesquisa esta foi exatamente a realidade encontrada, uma vez que os casos clínicos estudados já haviam sido anteriormente tratados, variando dentro dos últimos 29 anos de funcionamento da clínica do Departamento de Ortodontia da Faculdade de Odontologia de Bauru. Desta forma não existiam estas radiografias em todas as documentações selecionadas, impossibilitando a complementação do estudo com avaliações póstero-anteriores e submentonianas.

De qualquer modo, a partir do trabalho de ALAVI; BEGOLE; SCHNEIDER ${ }^{3}$, verificou-se a possibilidade de se avaliar assimetrias entre estruturas bilaterais em telerradiografias laterais, que rotineiramente compõem as documentações ortodônticas. Assim optou-se aqui por incluir as medições dos índices de assimetria entre algumas estruturas bilaterais maxila, mandíbula, primeiro molar superior e primeiro molar inferior - junto com as demais medidas cefalométricas avaliadas. Convém ressaltar que para a realização destas medições mostrou-se fundamental que as radiografias apresentassem boa qualidade de imagem, uma vez que as estruturas estudadas precisavam ser visualizadas individualmente, apesar da evidente sobreposição bilateral (parcial ou total). Um fator de maior dificuldade e imprecisão seria a dificuldade de identificação entre quais estruturas pertenceriam ao lado direito e quais seriam estruturas esquerdas. No entanto esta real dificuldade não teve influência nos resultados aqui encontrados, já que foram utilizadas apenas as diferenças em valores absolutos entre as estruturas bilaterais em relação à linha posterior de referência. 
Aparentemente, esta metodologia mostra ainda certa vantagem na avaliação das assimetrias ântero-posteriores entre os dentes molares em relação aos modelos em gesso, pois a utilização de uma linha vertical posterior, passando pelo Básio, oferece uma referência à relativa distância das estruturas avaliadas, resultando em uma medição mais precisa da posição espacial dos primeiros molares superiores e inferiores. Portanto, apesar da necessidade de grande concentração e precisão na realização dos traçados das estruturas bilaterais, existiu a possibilidade em se analisar as assimetrias entre algumas estruturas utilizando apenas as telerradiografias laterais, contribuindo com mais um grupo de informações ao estudo.

\subsubsection{Precisão da Metodologia}

Para que os resultados de uma pesquisa sejam confiáveis, HOUSTON ${ }^{54}$ indica que os traçados e medições sejam realizados duas vezes. Apesar de ser o ideal, quando isto não for possível, recomenda que se realize medição por uma segunda vez em radiografias selecionadas ao acaso. Neste estudo, selecionaram-se aleatoriamente dez telerradiografias para serem traçadas e medidas por uma segunda vez. Desta forma, calculou-se a precisão do investigador pelos erros intra-examinador, casuais e sistemáticos, tornando os resultados obtidos mais confiáveis.

A maior fonte de erros casuais (DAHLBERG ${ }^{35}$ ) acontece pela dificuldade de identificação de um ponto em particular ou pela imprecisão na definição de certos pontos. A grande maioria dos erros casuais encontrados nas medidas verificadas neste estudo foram bastante reduzidos, estando todos abaixo de 1 milímetro ou 1 grau (tabela 2), o que pode ser considerado bastante satisfatório, ao se comparar com a literatura ${ }^{1,44,92,101}$. A situação ideal no erro 
casual é aquela em que a média das diferenças iguala-se a zero, pois isso indica que os erros ocorreram de modo equilibrado nos dois sentidos, ou seja, tanto para mais como para menos. Quanto mais a média das diferenças afastar-se de zero, maior o sinal de ter havido uma tendência ao direcionamento dos resultados, de modo consciente ou não, seja subestimando-os ou superestimando-os ${ }^{108}$. Como os erros casuais para as variáveis em estudo foram pequenos, conclui-se que os desvios padrão encontrados realmente representem o reflexo da variabilidade dos grupos.

Os erros sistemáticos ocorrem quando um determinado parâmetro é persistentemente sub ou superestimado, podendo acontecer quando um pesquisador modifica a sua técnica de mensuração após certo período de tempo ou, quando ele tende subconscientemente a direcionar os resultados de acordo com as suas expectativas de resultados do estudo ${ }^{54,108}$. Neste trabalho, o teste $\mathrm{t}$ dependente foi utilizado para a verificação quanto à existência de erro sistemático significante. Pode-se verificar a ausência de significância na análise do erro sistemático para todas as variáveis avaliadas (tabela 2), o que favorece a confiabilidade tanto na metodologia aplicada como nos resultados alcançados. Somando-se a ausência de erros sistemáticos significantes, aos valores dos erros casuais inferiores a uma unidade de medida, pôde-se concluir que a metodologia empregada neste estudo apresentou precisão e confiabilidade necessárias para promoção de resultados transparentes e fidedignos. 


\subsection{Discussão dos Resultados}

\subsubsection{Compatibilidade dos grupos}

Apesar de uma seleção da amostra seguindo rigidamente os critérios já mencionados, não se pode descartar a possibilidade da existência de outras características que possam interferir e dificultar as terapêuticas realizadas. Deste modo, com a intenção de avaliar a magnitude desta possibilidade de variação, foram comparadas entre os grupos as variáveis a serem estudadas, previamente ao tratamento.

Ao se avaliar os resultados da tabela 5 , onde se realizou o teste $t$ independente, comparando os valores iniciais estudados entre os grupos, pode-se observar a ausência de diferença estatisticamente significante para todas as medições cefalométricas realizadas. Isto confirma um alto grau de compatibilidade entre os grupos estudados e isenção da interferência de características díspares nos resultados com os dois protocolos de tratamento estudados, conforme ilustrado na figura 8. 


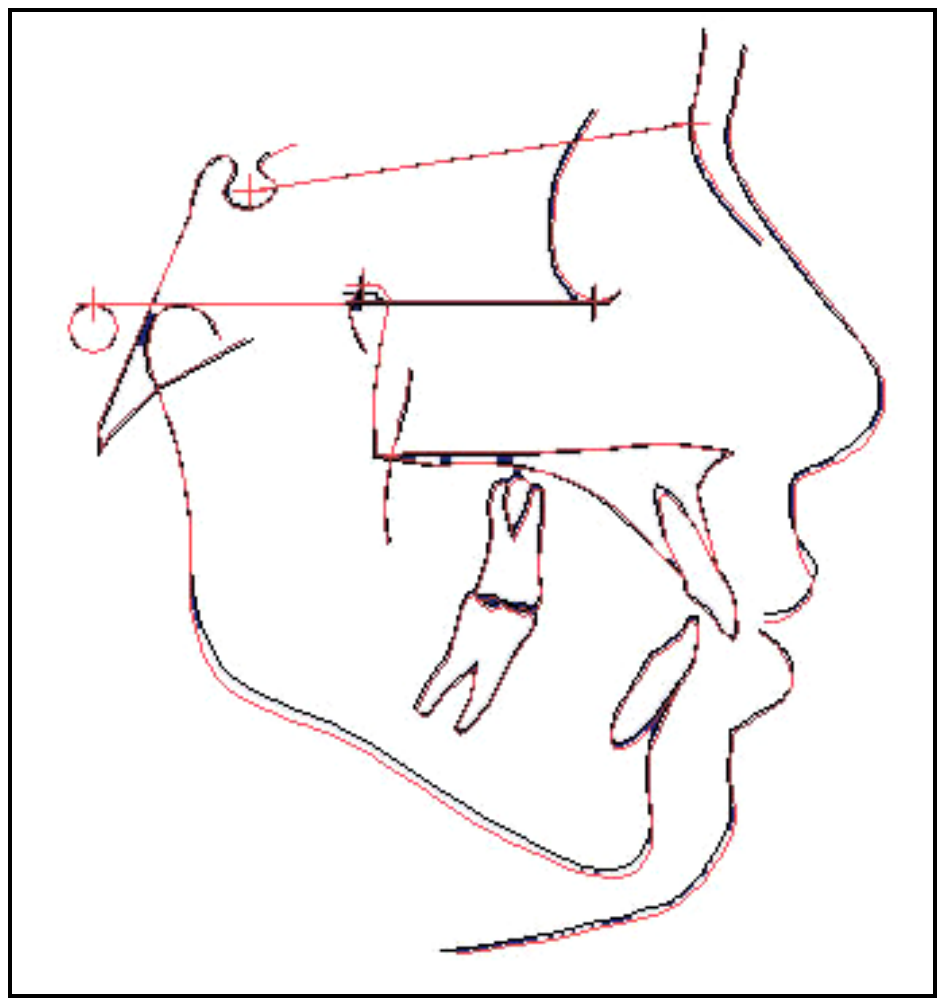

--- Grupo 1

--- Grupo 2

Figura 8: Sobreposição em SN, centrado em $\mathrm{S}$, dos traçados cefalométricos médios iniciais dos pacientes dos grupos 1 e 2 .

A avaliação dos valores iniciais confirmam compatibilidade dos grupos nos diversos componentes estudados, como uma ligeira deficiência no relacionamento ântero-posterior das bases apicais, compatível com valores tegumentares de convexidade do perfil e um padrão de crescimento próximo do equilíbrio, com um pequeno predomínio do componente vertical. A mesma sintonia foi verificada para os valores do componente dentoalveolar, onde tanto a inclinação como a protrusão dos incisivos superiores e inferiores apresentaram semelhança entre os grupos. Em concordância com esta similaridade, os índices de assimetria avaliados também apresentaram valores semelhantes entre os grupos ao início do tratamento ortodôntico. 
Dos dados que formam a tabela 5 , apenas os valores relativos às idades dos pacientes ao início do tratamento apresentaram diferença significante entre os grupos. Apesar da diferença média entre estas idades ter uma magnitude restrita à cerca de 13 meses, a média de idade dos pacientes do Grupo 1 foi significativamente maior que a médio do grupo 2, fator bastante compreensível. Sabe-se que a correção da relação ântero-posterior em uma má oclusão de Classe II torna-se mais difícil com o avançar da idade do paciente, porque o potencial de crescimento diminui progressivamente com a idade ${ }^{16,17,49,62}$. Nos casos de subdivisão, tratados com extrações de quatro prémolares, a relação do segmento posterior do lado da Classe II necessitará de ampla correção ântero-posterior; portanto consistindo em uma terapêutica mais viável de ser realizada em pacientes mais jovens. Em contrapartida, nos casos tratados com três extrações não há necessidade de correção ânteroposterior da relação molar; desta forma, a opção deste modo de correção em pacientes com idade mais avançada, proporcionará menores efeitos oclusais no sentido ântero-posterior, de maneira semelhante ao que ocorre nos casos de Classe II bilateral tratados com extrações de dois pré-molares superiores ${ }^{17,49,85,90}$. De qualquer maneira, esta diferença entre a média de idade dos grupos teria favorecido o protocolo de tratamento com quatro extrações ${ }^{17,62}$.

\subsubsection{Avaliação das alterações intergrupos}

A comparação dos resultados obtidos neste estudo, quanto às alterações realizadas entre os dois protocolos de tratamento ortodôntico, com outros trabalhos presentes na literatura apresenta certa limitação no fato dos principais trabalhos que abordam alterações do tratamento da má oclusão de Classe II, subdivisão, utilizarem metodologia distinta da aqui empregada ${ }^{62}$, ou 
seja, avaliação cefalométrica em telerradiografias laterais. Grande parte das pesquisas sobre o tema aborda principalmente resultados transversais, por meio de radiografias submentonianas ou póstero-anteriores, com indicada ênfase na posição e correção das linhas medianas dentárias e faciais ${ }^{3,7,34,44,59,73,84,101}$. Também com a orientação de verificar a compatibilidade de linhas medianas em tratamentos da Classe II, subdivisão, assim como a posição ântero-posterior dos dentes posteriores, outras pesquisas usaram a avaliação em modelos de gesso como metodologia ${ }^{3,37,62,77}$.

O presente estudo objetivou comparar as alterações cefalométricas que ocorreram com os dois protocolos de extrações avaliados nas diversas variáveis. Desta forma, cabe agora discutir estas diversas variáveis e suas contribuições, tanto pela comparação intergrupos das alterações ocorridas com o tratamento, como pela análise intragrupos das medidas iniciais e ao final da terapêutica. As alterações do componente maxilar (SNA e Co-A) não apresentaram diferença significante entre os grupos com os tratamentos realizados (tabela 6). O comportamento semelhante dos grupos parece bastante normal uma vez que o protocolo de extrações no arco dentário superior foi semelhante. As alterações na posição da maxila em relação à base craniana foram semelhantes, com discreta redução da protrusão maxilar nos dois grupos, sem significância mesmo na avaliação intragrupos de comparação entre o início e final do tratamento (tabelas 7 e 8). 0 comprimento efetivo da maxila revelou alterações em direções distintas entre os dois grupos, entretanto com uma magnitude insuficiente para mostrar significância. Apenas no grupo 1 houve alteração estatisticamente significante da variável Co-A entre o início e o término da correção, com aumento médio da ordem de 1 milímetro. Tal resultado, apesar de não demonstrar comportamento diferente estatisticamente em relação ao grupo 2, deve estar relacionado a menor necessidade da utilização de recursos ortodônticos para 
correção da relação molar no grupo 1. Uma vez que os pacientes pertencentes ao grupo 2 foram tratados com o objetivo de finalização com relação molar de Classe I bilateral, este grupo necessitou de maior utilização de recursos como elásticos intermaxilares de Classe II ou aparelho extrabucal com tração assimétrica. Acredita-se que estes recursos foram os principais responsáveis pelo comportamento ligeiramente distinto dos grupos quanto ao componente maxilar, apresentando uma redução do SNA ligeiramente superior e restringindo o crescimento do comprimento maxilar no grupo 2; no entanto sem magnitude suficiente para demonstrar significância estatística. Este redirecionamento do crescimento maxilar com a utilização de ancoragem extrabucal ou elásticos intermaxilares costuma levar a uma restrição do deslocamento anterior do ponto $A^{8,11,29,49,52,86,90,100,126,142}$. A expectativa de que estes recursos tenham contribuído por esses comportamentos maxilares ligeiramente diferentes entre os grupos é confirmado pela literatura, ao se verificar comportamento cefalométrico semelhante nos casos de Classe II bilateral tratados com extrações de quatro pré-molares ${ }^{27,47,49,52,71}$. De modo semelhante ao que ocorre em casos de Classe II bilateral tratados com extrações de dois pré-molares, o tratamento da subdivisão com três extrações costuma também necessitar de reforços de ancoragem, porém em menor intensidade do que os casos realizados com quatro extrações ${ }^{17}$, apresentando portanto menor restrição do crescimento maxilar nestes pacientes.

Quanto ao componente mandibular, também não ocorreu diferença estatisticamente significante entre as alterações verificadas com o tratamento recebido pelos grupos 1 e 2 (tabela 6). Tanto a protrusão mandibular em relação à base do crânio, como o comprimento efetivo da mandíbula tiveram aumento do valor de suas grandezas nos dois grupos, de forma semelhante estatisticamente. O aumento do valor de Co-GN apresentou magnitude semelhante entre os grupos, tendo apresentado significância na comparação 
inicial e final intragrupo para os dois grupos (tabelas 7 e 8). Este comportamento era esperado uma vez que os pacientes que compunham a amostra apresentavam certa quantidade de crescimento devido às idades médias iniciais, crescimento este confirmado pelo aumento nos dois grupos do comprimento efetivo da mandíbula. A alteração do valor de SNB entre o inicio e o final do tratamento apresentou significância apenas no grupo 2, apesar de ter alterado no mesmo sentido nos dois grupos. Esta diferença, apesar de insuficiente para demonstrar significância entre os grupos, é pertinente à idade média menor observada no grupo 2, levando a uma expectativa de crescimento mandibular maior neste grupo. Esta maior intensidade de alteração do ângulo SNB no grupo 2 ainda favoreceu a eficiência do protocolo de tratamento escolhido para estes pacientes, onde um maior crescimento mandibular foi benéfico à correção da relação molar do lado da Classe II.

Baseado nos dados discutidos para os componentes maxilar e mandibular, as grandezas estudadas quanto ao relacionamento entre maxila e mandíbula, também mantiveram concordância com as expectativas, ocorrendo alterações significantes intragrupos entre o início e término do tratamento nos dois grupos estudados, tanto para o ângulo ANB como para a Diferença Maxilo-mandibular (tabelas 7 e 8). O comportamento do ângulo ANB esteve de acordo com o reportado pela literatura na correção das más oclusões de Classe II, onde ocorreu redução da medida nos dois grupos, de modo semelhante estatisticamente (tabela 6). Apesar de não deflagrar diferença entre os grupos, esta redução foi maior no grupo 2, tratado com extrações de quatro pré-molares, fator também relacionado a maior necessidade de recursos para a correção da relação molar no lado da Classe II, que secundariamente geraram maiores conseqüências esqueléticas nestes pacientes. O comportamento da Diferença Maxilo-mandibular também se apresentou semelhante ao ocorrido com o ângulo ANB, apresentando um 
aumento da diferença entre o início e término do tratamento semelhante para os dois grupos, sendo entretanto, em média absoluta, ligeiramente superior para o grupo 2, com idade média menor. Apesar de não ser o objetivo principal dos tratamentos realizados, nos dois grupos estudados, os valores do componente relativo à relação da maxila e mandíbula no sentido ânteroposterior foram influenciados no sentido de valores referentes de normalidade, trazendo conseqüências benéficas ao relacionamento esquelético dos pacientes ao fim do tratamento.

Verificou-se nas medidas do componente de padrão de crescimento uma semelhança entre os dois grupos deste trabalho, onde ocorreu uma ligeira redução das medidas angulares e um aumento do AFAl linear (tabela 6). Apesar de parecerem dados conflitantes numa primeira observação, estas grandezas mostram um comportamento compreensível como de aumento generalizado das dimensões verticais da face, entretanto com uma maior intensidade na região facial posterior, com conseqüente redução dos ângulos do padrão esqueleto-cefálico, estando de acordo com o crescimento normal esperado no período estudado ${ }^{78}$. Mostra-se importante reafirmar que este comportamento do padrão facial seguiu um comportamento estatisticamente semelhante durante o tratamento, para ambos os grupos, denotando ausência de influência da diferença das mecânicas ortodônticas empregadas sobre o padrão de crescimento facial dos pacientes.

A avaliação das alterações intragrupos entre o início e final dos tratamentos mostrou significância estatística para o aumento da medida linear AFAl, para os dois grupos (tabelas 7 e 8). As variáveis angulares não apresentaram alterações significantes com o tratamento ortodôntico, a exceção do valor de FMA para o grupo 1. Apesar desta significância apenas para os pacientes tratados com extrações de três pré-molares, isto não foi 
suficiente para denotar comportamento distinto entre os grupos na comparação intergrupo das alterações com o tratamento (tabela 6).

O comportamento dos grupos estudados quanto ao padrão facial encontrou concordância com os resultados do deslocamento vertical dos molares superiores e inferiores, onde ocorreu aumento significante destas grandezas (U6-PP E L6-PM) entre o início e término do tratamento para os grupos 1 e 2 (tabelas 7 e 8), porém sem diferença significante do comportamento entre os grupos (tabela 6). Este aumento vertical dos molares, além de estar de acordo com o desenvolvimento normal de pacientes nesta idade $^{78}$, mostrou-se compatível com o desenvolvimento facial vertical posterior verificado pelas variáveis do padrão de crescimento. A similaridade do comportamento das amostras pesquisadas em relação a pacientes com crescimento facial normal denota uma influência pouco significante da mecânica ortodôntica, empregada em ambos protocolos avaliados, no controle vertical dos molares.

Quanto ao componente horizontal dos molares superiores e inferiores, os dois grupos apresentaram alterações significantes entre o início e término do tratamento na comparação intragrupo (tabelas 7 e 8), com aumento das distâncias entre as cúspides mésio-vestibulares dos primeiros molares em relação à linha PTV compatíveis com o crescimento facial normal para o período estudado ${ }^{2,78}$. Pode-se verificar um comportamento estatisticamente semelhante destas alterações entre os grupos (tabela 6), independente do tratamento ortodôntico realizado. Entretanto, apesar da ausência de significância, o aumento da distância U6-PTV foi menor no grupo 2, tratado com quatro extrações, o que colabora com a idéia de uma maior influência dos recursos para correção da relação molar de Classe II neste grupo, que teriam proporcionado uma relativa restrição ao deslocamento mesial do molar 
superior deste lado, influenciando o comportamento médio entre os molares direito e esquerdo ${ }^{21,68,96}$.

As variáveis responsáveis pela avaliação do componente dentoalveolar superior anterior, aqui verificadas, demonstraram um comportamento semelhante entre os grupos estudados, independente dos diferentes protocolos de terapêutica utilizados, na comparação intergrupos das alterações alcançadas (tabela 6). Os incisivos superiores foram retraídos na maxila, assim como tiveram suas inclinações vestibulares reduzidas com os tratamentos (figuras 9 e 10), em concordância com o relatado na literatura nos diversos métodos de tratamento da má oclusão de Classe II, principalmente quando da inclusão de extrações de pré-molares superiores ${ }^{12,13,17,27,75,90,107,118}$.

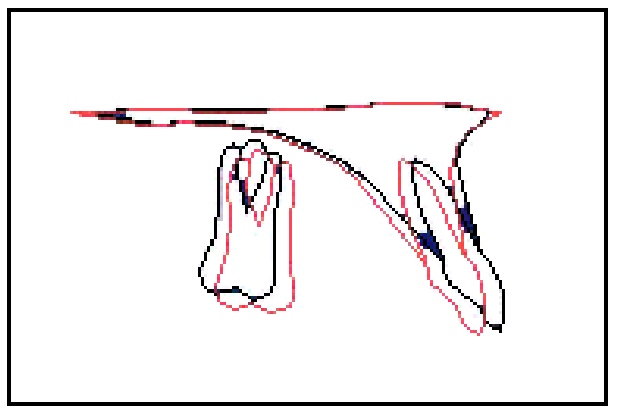

Figura 9: Sobreposição no Plano Palatino, centrado em ENA, dos traçados cefalométricos maxilares médios do grupo 1 , nas fases inicial (T1) e final (T2).

\section{--- T1}

--- T2

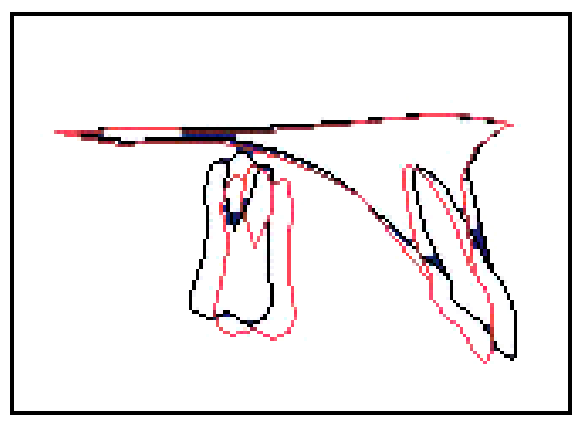

Figura 10: Sobreposição no Plano Palatino, centrado em ENA, dos traçados cefalométricos maxilares médios do grupo 2, nas fases inicial (T1) e final (T2). 
Esta retrusão dos incisivos superiores, avaliada pelas medidas 1-Aperp, 1.PP, 1-NA e 1.NA, apesar de estatisticamente semelhante entre os grupos, foi maior para os pacientes do grupo 2; fato concordante com a mecânica adotada neste grupo, onde houve maior necessidade de retração dos incisivos superiores em razão da necessidade de correção da relação molar do lado da Classe II e da maior retrusão dos incisivos inferiores, conforme o planejamento. No grupo que recebeu tratamento com três extrações, apesar da igual necessidade em fechamento de espaço das extrações realizadas, o planejamento não indicava alteração das relações molares existentes inicialmente, fator que favoreceu uma menor quantidade de retrusão dos incisivos nestes casos, entretanto sem magnitude suficiente para acusar significância. Outro fator que colaborou para uma menor retração dos incisivos superiores no grupo 1 consistiu na menor quantidade de retração observada nos incisivos inferiores dos pacientes deste grupo, proporcionando uma boa relação interincisal mesmo com menor quantidade de retração superior. Esta menor alteração da relação horizontal entre os incisivos no grupo tratado com três extrações, em relação à realização do tratamento com quatro extrações, encontra suporte em tendência semelhante observada no comportamento destes mesmos protocolos de correção quanto a sobressaliência na pesquisa realizada por JANSON et al. ${ }^{62}$. As alterações intragrupos para estas mesmas grandezas (tabelas 7 e 8) demonstram alterações significantes entre o início e o término do tratamento para todas as variáveis citadas no grupo 2 , sempre na direção de retração e verticalização dos incisivos superiores. Já no grupo 1 , as variáveis que mostraram alterações significantes com o tratamento foram apenas às relativas à posição ântero-posterior dos incisivos (1-NA e 1-Aperp), enquanto as variáveis que mediram a inclinação dos incisivos não demonstraram alterações significativas com o tratamento. Uma suposição a respeito do comportamento intragrupo distinto, observado entre os grupos, para a influência dos 
protocolos de tratamento sobre a inclinação dos incisivos superiores recai na maior necessidade de utilização de elásticos intermaxilares nos pacientes tratados com extração de quatro pré-molares; entretanto é importante ressaltar que esta diversidade de significância intragrupo não foi de intensidade suficiente para gerar diferença estatística significante na comparação intergrupos das alterações geradas pelos tratamentos distintos. Efeitos colaterais sobre a inclinação dos incisivos em pacientes tratados com elásticos intermaxilares são amplamente relatados na literatura, suportando esta suposição $0^{4,21,41,46,50,59,68,74,96,109,122}$.

A mesma hipótese de interferência dos elásticos intermaxilares nos resultados do grupo tratado com extração de quatro pré-molares também parece razoável quanto ao posicionamento vertical dos incisivos superiores, verificado pela variável 1-PP. Para esta grandeza também ocorreu um comportamento estatisticamente semelhante entre os grupos, quando foram comparadas as alterações causadas pelos dois protocolos de tratamento, tendo sido evidenciado pequena extrusão dos incisivos nos dois grupos (tabela 6). No entanto, a análise das tabelas 7 e 8, que mostram a significância intragrupos entre o início e término do tratamento, demonstra que apenas para o grupo 2 houve significância para esta alteração, sugerindo pertinência na suposição de maior influência dos elásticos intermaxilares neste grupo.

O comportamento do componente dentoalveolar anterior inferior representa um ponto central deste trabalho. Devido à distinção entre os protocolos localizar-se principalmente no arco dentário inferior, com a extração de um pré-molar a menos no grupo 1, a própria literatura sugeria a presença de diferenças estatísticas no comportamento da posição dos incisivos inferiores e conseqüentemente seus reflexos no perfil 
tegumentar $25,34,59,62,61,69$, o que até o presente não era suportado por maiores comprovações científicas. Os resultados encontrados neste estudo comprovam uma retrusão significativamente menor dos incisivos inferiores nos casos tratados com extração de três pré-molares (tabela 6 e figura 11), quando comparado ao grupo corrigido com quatro extrações, segundo as grandezas 1-NB e 1-Bperp. A maior alteração nestas grandezas, durante o tratamento do grupo 2, confirma que a realização do tratamento com extração de dois pré-molares no arco inferior aumentou significativamente a quantidade final de retração dos incisivos inferiores. Apesar da variável 1-Bperp ter apresentado alteração significante entre o início e o fim do tratamento também para o grupo 1 , fato bastante aceitável tendo em vista que foi realizada a extração de um pré-molar e conseqüente retração ântero-inferior, esta alteração foi menor do que a verificada para o grupo 2; além de que a variável 1-NB demonstrou alteração significante apenas com o tratamento ortodôntico realizado com quatro extrações, fortalecendo a diferença entre os grupos quanto à quantidade de retrusão dos incisivos inferiores (figuras 12 e 13). Como previamente citado, esta maior retração dos incisivos inferiores também fornece mais uma razão para a verticalização dos incisivos superiores ter apresentado significância apenas no grupo 2, fator provavelmente necessário para o alcance de uma relação interincisal adequada ${ }^{17,75,129,130}$. 


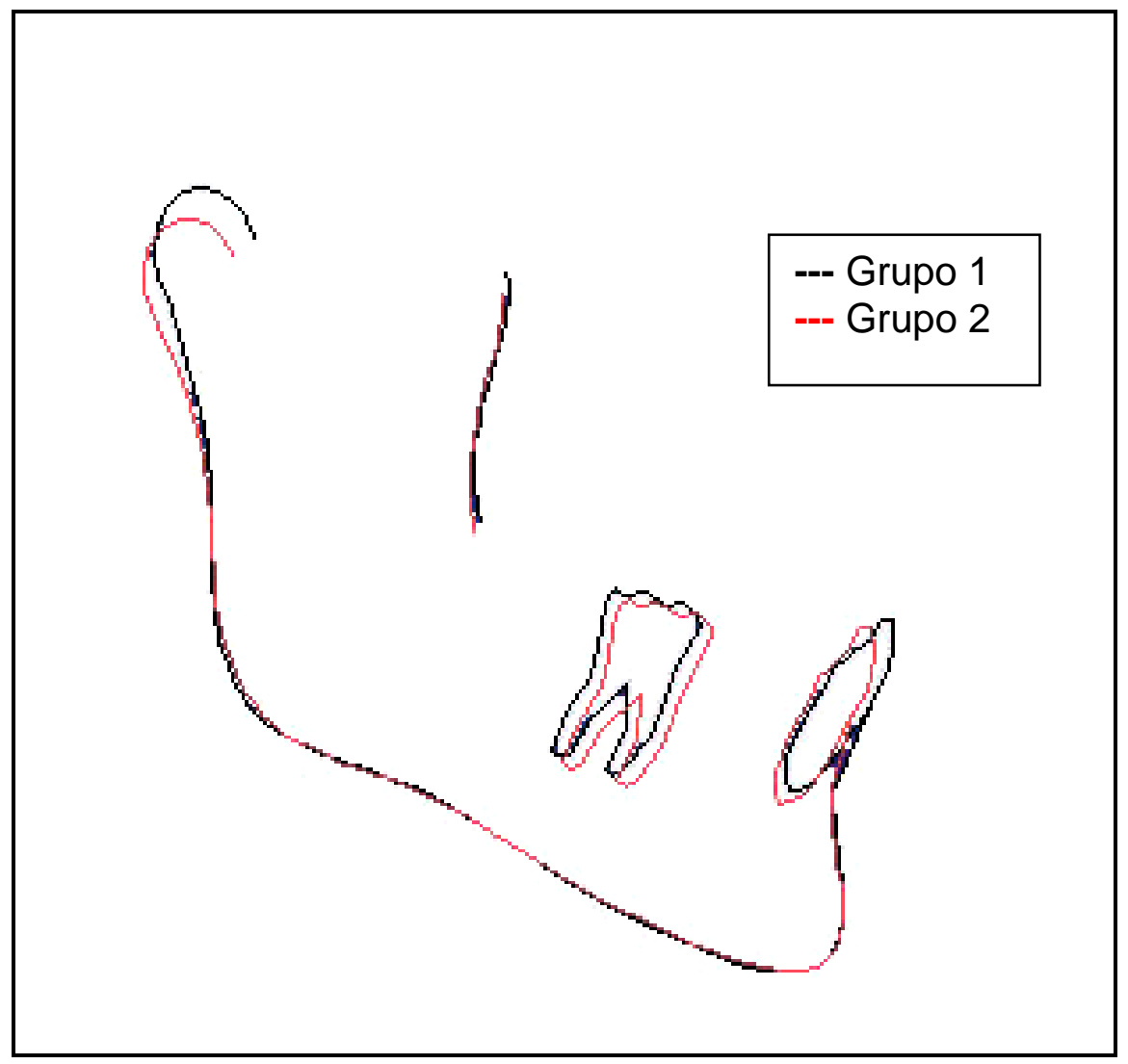

Figura 11: Sobreposição no Plano Mandibular, centrado em Gn, dos traçados cefalométricos mandibulares médios finais dos pacientes dos grupos 1 e 2 . 


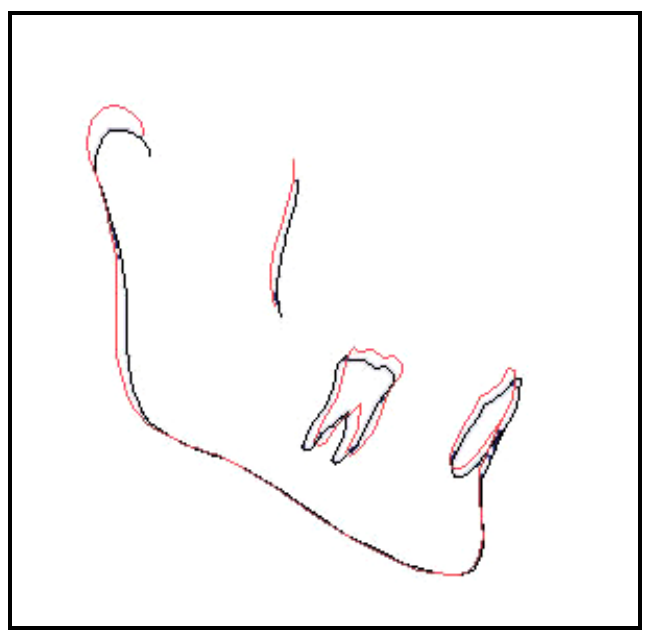

Figura 12: Sobreposição no

Plano Mandibular, centrado em $\mathrm{Gn}$, dos traçados cefalométricos mandibulares médios do grupo 1 , nas fases inicial (T1) e final (T2).

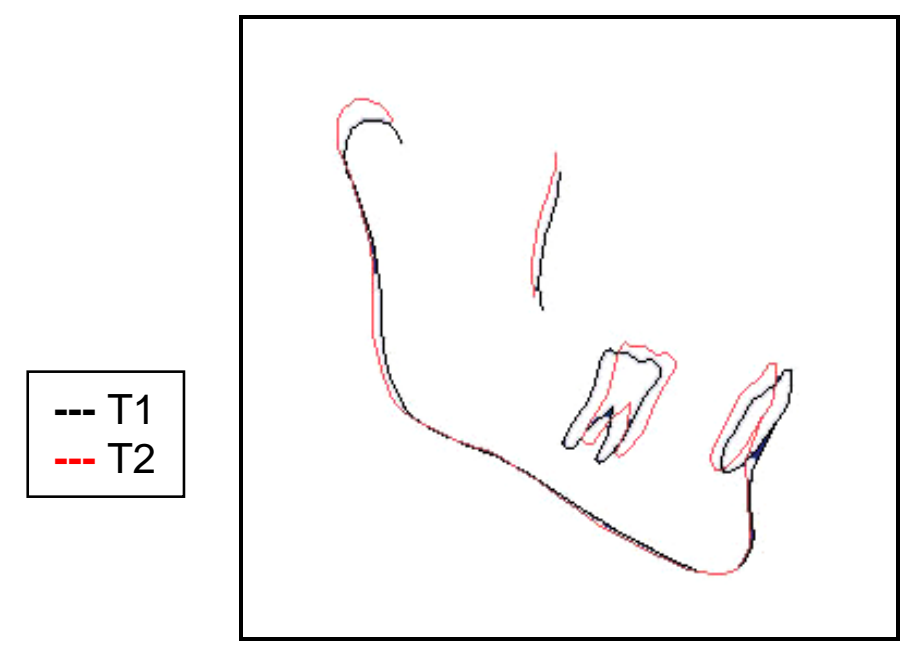

Figura 13: Sobreposição no Plano Mandibular, centrado em Gn, dos traçados cefalométricos mandibulares médios do grupo 2, nas fases inicial (T1) e final (T2).

Quanto às grandezas que avaliaram as alterações de inclinação dos incisivos inferiores com os distintos protocolos de tratamento estudados, observou-se concordância de resultado entre os grupos, com ausência de diferença estatística significante nas alterações recebidas; entretanto as alterações intragrupo mostraram significância estatística entre o início e término do tratamento apenas para os pacientes do grupo 2, onde a redução da inclinação dos incisivos apresentou valores mais altos. Apesar do comportamento estatisticamente semelhante dos grupos, a menor quantidade de verticalização dos incisivos inferiores nos pacientes tratados com três extrações relaciona-se a menor retração incisal neste grupo, devido à extração de apenas um dente no arco inferior, em relação ao tratado com quatro extrações. Esta tendência da inclinação encontra-se de acordo com o 
verificado para as medidas lineares, diferindo apenas por não despertar significância estatística.

O comportamento vertical dos incisivos inferiores apresentou comportamento adverso às expectativas, uma vez que ocorreu diferença estatisticamente significante do comportamento entre os grupos (tabela 6), sendo que os pacientes do grupo 1 apresentaram aumento de sua posição vertical, enquanto os casos do grupo 2 tiveram ligeira restrição vertical com a mecânica empregada. A análise das alterações intragrupo (tabelas 7 e 8) demonstra que as alterações entre o início e o final do tratamento foram significantes apenas para os pacientes tratados com extrações de três prémolares, onde a distância entre a borda incisal do incisivo inferior e o plano mandibular aumentou em cerca de um milímetro. Como o trabalho de JANSON et al. ${ }^{62}$ mostrou uma maior redução da sobremordida nos casos tratados com três extrações, mesmo que sem apresentar diferença significante entre os grupos, além do fato da mecânica realizada com quatro extrações necessitar de maior uso de elásticos intermaxilares, esperava-se que o comportamento aqui avaliado ocorresse de modo oposto. Este comportamento vertical inesperado dos incisivos inferiores, principalmente nos pacientes do grupo 1, pode estar relacionado a uma certa perda do controle vertical ântero-inferior nestes casos tratados com extrações de três pré-molares.

Estes achados científicos quanto ao comportamento dos componentes dentoalveolares anteriores, tanto superior como inferior, repercutem em conseqüências diretas nos resultados observados no componente tegumentar aqui estudado, estando de acordo com a literatura ${ }^{25,69,107,122,134}$. Em sintonia com o fato de uma significativa maior retrusão dos incisivos inferiores no grupo tratado com quatro extrações (figuras 14, 15 e 16), duas variáveis 
tegumentares estudadas (H.NB e H-Nariz) apresentaram comportamento estatisticamente diferente entre os grupos, perante os tratamentos realizados, onde os pacientes tratados com três extrações receberam menores alterações no perfil tegumentar, enquanto os casos do grupo 2 tiveram uma maior retrusão do perfil facial. Apenas a medida $\mathrm{H}$-Li apresentou comportamento estatisticamente semelhante frente aos dois protocolos de tratamento, porém em valores absolutos com maior retração do lábio inferior nos pacientes do grupo 2. Aliás, esta variável apresentou alteração significante entre o início e o final da correção ortodôntica apenas para o grupo 2 (tabela 7), enquanto no grupo 1 a alteração na posição do lábio inferior não foi alterada significativamente com o tratamento realizado (tabela 8).

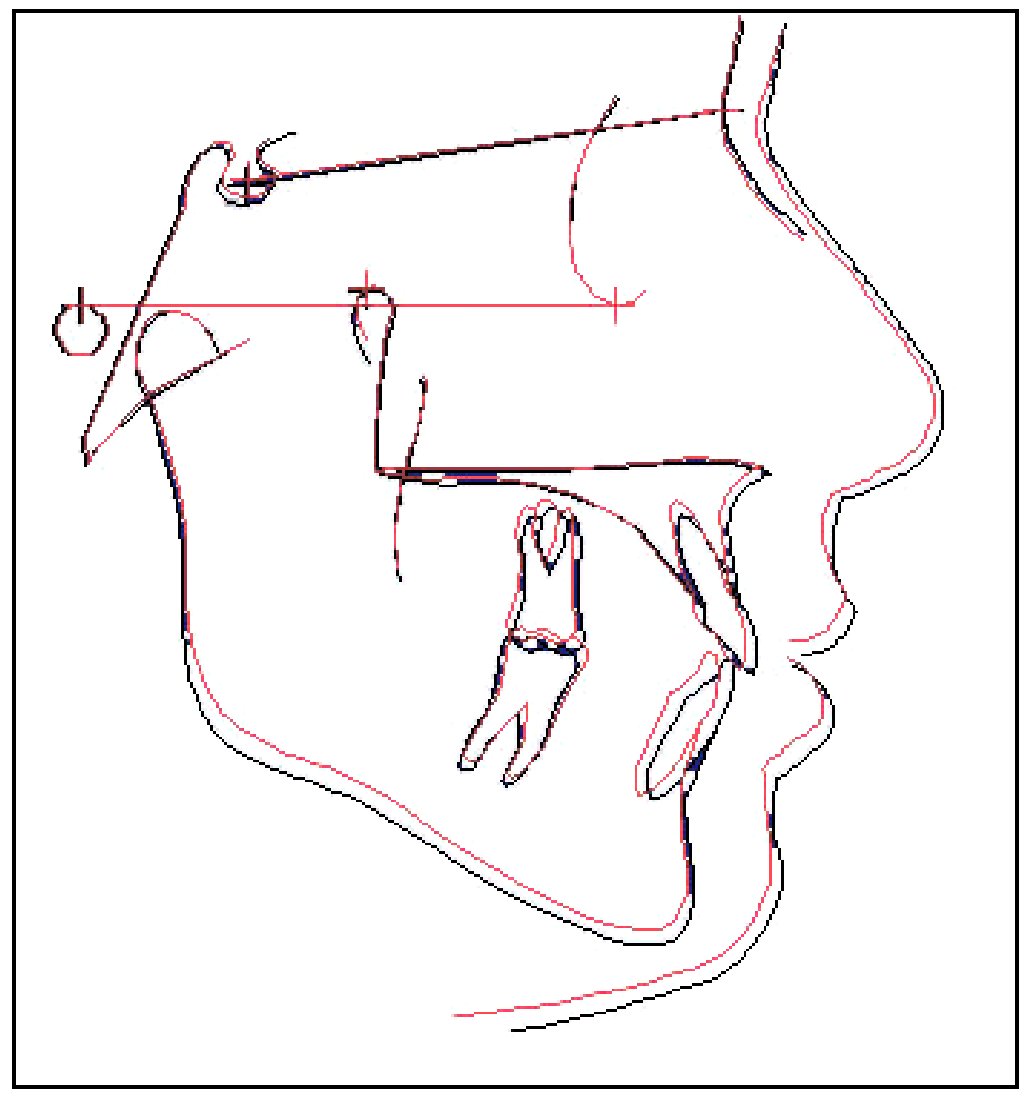

--- Grupo 1

--- Grupo 2

Figura 14: Sobreposição em SN, centrado em $\mathrm{S}$, dos traçados cefalométricos médios finais dos pacientes dos grupos 1 e 2 . 


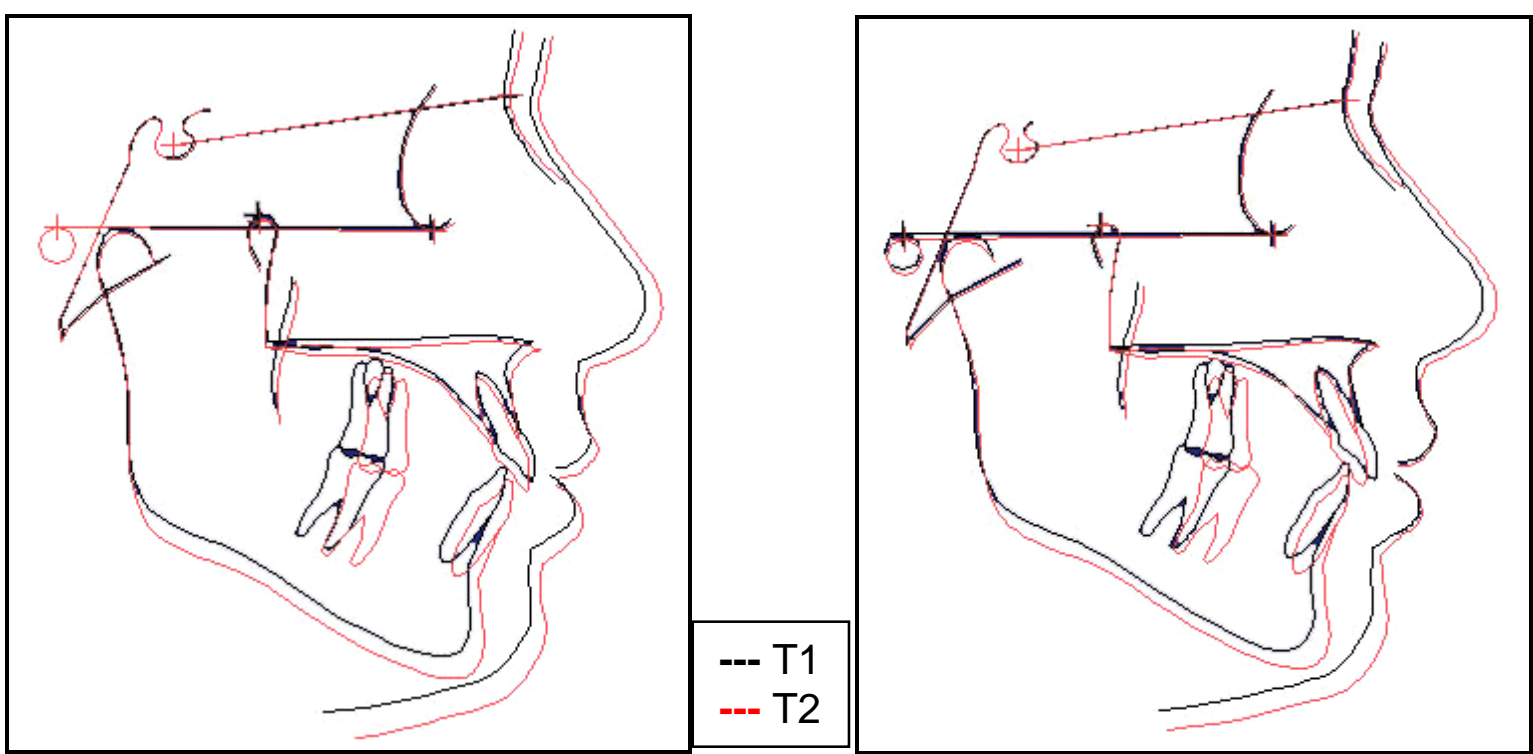

Figura 15: Sobreposição em

Figura 16: Sobreposição em $\mathrm{SN}$, centrado em S, dos traçados cefalométricos médios $\mathrm{SN}$, centrado em S, dos traçados cefalométricos médios do grupo 1, nas fases inicial (T1) e final (T2). do grupo 2, nas fases inicial (T1) e final (T2).

O último componente estudado a ser discutido corresponde aos índices de assimetrias. Dentre os quatro índices avaliados, apenas o relativo a assimetria dos molares inferiores, direito e esquerdo, mostrou alteração diferente estatisticamente entre os dois protocolos de tratamento realizados. No grupo 1 houve um aumento significante da assimetria dos molares inferiores entre o início e o término da correção ortodôntica, claramente previsível, uma vez que a extração no arco inferior foi assimétrica para este grupo. Já no grupo 2, onde o protocolo de tratamento buscava uma relação molar de Classe I bilateral, ocorreu uma redução no índice de assimetria do molar inferior, mesmo que sem significado estatístico. Esta diferença no comportamento da assimetria dos molares inferiores, entre os grupos, foi 
proporcionada por mecânicas diferentes de tratamento, onde a aceitação de uma relação molar de Classe II no grupo 1 foi fator preponderante para otimizar a correção do desvio da linha média. Esta correção, mecanicamente mais viável no grupo tratado com extração inferior assimétrica, mostrou-se também mais eficiente no trabalho de JANSON et al. ${ }^{62}$ (2003). As alterações nos demais índices de assimetria estudados não foram suficientes para denotar qualquer significância estatística, tanto na análise intragrupo (tabelas 7 e 8) como na das alterações intergrupos (tabela 6). Entretanto, mesmo que sem pertinência estatística, a assimetria entre os molares superiores foi ligeiramente reduzida em ambos os grupos, apresentando uma intensidade cerca de quatro vezes maior no grupo tratado com quatro extrações. Esta maior alteração nos pacientes do grupo 2 relaciona-se a necessidade de correção da relação molar no lado de Classe II, sendo efeito principalmente de recursos como os elásticos intermaxilares ${ }^{4,41,46,50,59,74,109,114,122}$.

\subsubsection{Implicações Clínicas}

Os principais resultados deste trabalho estão relacionados à diferença na quantidade de retrusão dos incisivos inferiores e suas conseqüentes alterações no perfil tegumentar realizadas pelos dois tipos de tratamentos ortodônticos da Classe II, subdivisão, aqui estudados: com extração de três pré-molares, dois superiores e um inferior, ou extração de quatro pré-molares. Os dados aqui verificados demonstram uma significativa menor retração dos incisivos inferiores nos casos tratados com três extrações. Esta menor retração incisal acabou por criar uma menor alteração no perfil tegumentar dos pacientes tratados com este protocolo. Um perfil facial mais preenchido, conseqüentemente, menos achatado na região dos lábios, tem se mostrado mais desejável do ponto de vista estético facial nos mais diversos grupos 
étnicos ${ }^{51,91,106,128,135,144}$, principalmente em pacientes de origem latinoamericana ${ }^{5,38,43,56}$. Com esta intenção, mostram-se claras as vantagens do tratamento da má oclusão de Classe II, subdivisão, realizada com extrações de três pré-molares, proporcionando uma menor retrusão dos incisivos, com boa relação interincisal, e um perfil facial mais harmonioso, segundo parâmetros atuais. Estas vantagens do tratamento com três extrações, aqui evidenciadas, somam-se a tendência encontrada por JANSON et al. ${ }^{62}$ de maior sucesso com a utilização deste protocolo de extrações em comparação a casos tratados com quatro extrações, principalmente quanto à correção do desvio de linha média. Nos casos mais freqüentes desta má oclusão, onde o desvio encontra-se na linha média inferior ${ }^{3,59}$, a indicação mais favorável representa o protocolo com extração assimétrica de três pré-molares, desde que o perfil facial permita ligeira retração ${ }^{25,26,69}$; pois além de obter resultados mais favoráveis, representa um protocolo onde há menor necessidade de dependência na cooperação por parte do paciente pa,53,62,61,136 $_{\text {. }}$

\subsection{Sugestões de trabalhos futuros}

- Estudo comparativo das alterações cefalométricas do tratamento da má oclusão de Classe II, subdivisão, realizado com extrações de três prémolares com o de extração de um pré-molar superior.

- Avaliação cefalométrica da estabilidade a longo prazo do tratamento da má oclusão de Classe II, subdivisão, realizados com extrações de quatro ou de três pré-molares. 


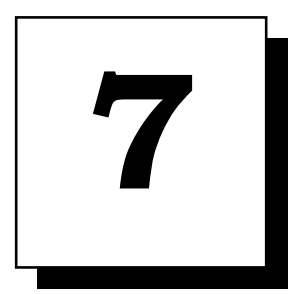

CONCLUSÕES 


\section{CONCLUSÕES}

De acordo com a metodologia utilizada e com os resultados obtidos em relação às alterações obtidas com o tratamento da má oclusão de Classe II, subdivisão, segundo os dois protocolos de extrações estudados, a hipótese nula foi rejeitada porque:

7.1 - Houve diferença significante entre as alterações proporcionadas pelos dois tratamentos em relação ao componente dentoalveolar ânteroinferior, onde a terapêutica realizada com três extrações propiciou menor retração dos incisivos inferiores.

7.2 - Houve menor retrusão do perfil tegumentar nos casos tratados com o protocolo de três extrações em relação aos pacientes do grupo corrigido com extrações simétricas de quatro pré-molares.

7.3 - O índice de assimetria dos molares inferiores no grupo tratado com extrações assimétricas aumentou e sua alteração se mostrou significantemente diferente do grupo com extrações simétricas de quatro prémolares. 


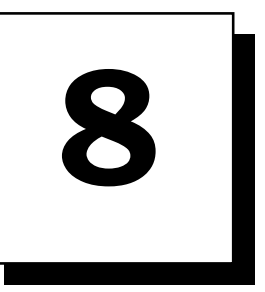

REFERÊNCIAS

BIBLIOGRÁFICAS 


\section{REFERÊNCIAS BIBLIOGRÁFICAS}

1. ADENWALla S.T.; KRONMAN, J.H.; ATTARZADEH, F. Porion and condyle as cephalometric landmarks - an error study. Amer. J. Orthodont. Dentofac. Orthop., v.94, n.5, p.411-5, Nov. 1988.

2. ÁGUILA F.J.; ÁGUILA, G. Atlas de cefalometria. 1 ed. São Paulo, Pancast, 1993.

3. ALAVI D.G.; BEGOLE, E.A.; SCHNEIDER, B.J. Facial and dental arch asymmetries in class II subdivision malocclusion. Amer. J. Orthodont. Dentofac. Orthop., v.93, n.1, p.36-46, Jan. 1988.

4. ALEXANDER R.G. The Alexander discipline. 1 ed. Glendora - CA, Ormco, 1987.

5. ALMEIDA A.B.; MAZZIEIRO, E.T. Considerações sobre a estética facial relevantes no diagnóstico e no planejamento ortodôntico. R. Dental Press Ortodon. Ortop. Facial, v.8, n.3, p.101-7, maio/jun. 2003.

6. ANGLE E.H. Classification of malocclusion. Dental Cosmos, v.41, n.3, p.248-64, Mar. 1899.

7. ARNOLD T.G.; ANDERSON, G.C.; LILYEMARK, W.F. Assessment of craniofacial asymmetry with S-V radiographs. Amer. J. Orthodont. Dentofac. Orthop., v.106, n.3, p.250-6, Sept. 1994. 
8. ARVYSTAS M.G. Nonextraction treatment of class II, division 1 malocclusions. Amer. J. Orthodont., v.88, n.5, p.380-95, Nov. 1985.

9. AZAZ B.; NITZAN, D.W.; BRIN, L. Condylar hyperplasia: remodeling of facial structures following condylectomia: report of two cases. Int. J. Orthodont. Orthog. Surg., v.6, n.1, p.47-55, Mar. 1991.

10. BAUMRIND S.; FRANTZ, R. The reability of head films measurements. Amer. J. Orthodont., v.60, n.2, p.111-27, Aug. 1971.

11. BERGAMINI A.; MELSEN, B. Case report: treatment of dental asymmetry. Angle Orthodont., v.31, n.4, p.247-52, July 1995.

12. BISHARA S.E. et al. Effects of orthodontic treatment on the growth of individuals with class II, division 1 malocclusion. Angle Orthodont., v.64, n.3, p.221-30, 1994.

13. BISHARA S.E. et al. Dentofacial and soft tissue changes in class II, division 1 cases treated with and without extractions. Amer. J. Orthodont. Dentofac. Orthop., v.107, n.1, p.28-37, Jan. 1995.

14. BISHARA S.E.; BURKEY, P.S.; KHARAOUF, J.G. Dental and facial asymmetries: a review. Angle Orthodont., v.64, n.2, p.89-98, 1994.

15. BISHARA S.E.; TREDER, J.E.; JAKOBSEN, J.R. Facial and dental changes in adulthood. Amer. J. Orthodont. Dentofac. Orthop., v.106, n.2, p.175-86, Aug. 1994. 
16. BJÖRK A. Prediction of mandibular growth rotation. Amer. J. Orthodont., v.55, p.585-99, June 1969.

17. BRAMBILLA A.C. Comparação dos resultados oclusais do tratamento da classe II realizado com extrações de dois pré-molares, com a terapêutica utilizando as extrações de quatro pré-molares. Bauru, 2002. 94p. Dissertação (Mestrado) - Faculdade de Odontologia de Bauru, Universidade de São Paulo.

18. BRANGELI L.A.M. et al. Estudo comparativo da análise cefalométrica pelo método manual e computadorizado. Rev. Assoc. Paul. Cir. Dent., v.54, n.3, p.234-41, mai./jun. 2000.

19. BREAKSPEAR E.K. Some aspects of the retraction of upper incisors by appliances. $38^{\text {th }}$ congress, European Orthodontic Society. J. Europ. Orthodont. Soc., p.342, 1963.

20. BRUM S. Archieving improved visualizatios of the temporoandibular joint condyle and fossa in sagittal cephalogram and a pilot study of their relationships in habitual occlusion. Amer. J. Orthodont. Dentofac. Orthop., v.109, n.6, p.635-8, June 1996.

21. BUCHIN I.D. JCO interviews. J. clin. Orthodont., v.1, n.11, p.103-10, Nov. 1967.

22. BURSTONE C.J. The intertegumental profile. Amer. J. Orthodont., v.44, n.1, p.1-25, Jan. 1958. 
23. BURSTONE C.J. JCO interviews:on the uses of the computer in orthodontic practice (part 1). J. clin. Orthodont., v.13, n.7, p.442-53, July 1979.

24. BURSTONE C.J. Diagnosis and treatment planning of patients with asymmetries. Seminars in Orthodontics, v.4, n.3, p.153-64, Sept. 1998.

25. CAPELLI JUNIOR J.; TIBANA, R.H.W. Alterações no perfil facial em indivíduos submetidos a tratamento ortodôntico com extrações de quatro pré-molares. Ortodontia Gaúcha, v.4, n.1, p.35-45, jan./jun. 2002.

26. CARVALHO A.B. et al. Estudo da proporção de retração dos lábios em relação à retração dos incisivos em pacientes com maloclusão classe II, divisão 1 de Angle tratados com a técnica do arco de canto e extrações de pré-molares. J. Bras. Ortodon. Ortop. Facial, v.4, n.24, p.476-85, 1999.

27. CARVALHO P.E.G. A influência do padrão de crescimento facial anterior na correção da má oclusão de classe II, 1 divisão, realizada com aparelho fixo, extração dos primeiros pré-molares e ancoragem extrabucal cervical. Bauru, 2000. 181p. Dissertação (Mestrado) - Faculdade de Odontologia de Bauru, Universidade de São Paulo.

28. CASSIDY D.W. et al. A comparison of surgery and orthodontics in "borderline" adults with class II, division 1 malocclusions. Amer. J. Orthodont. Dentofac. Orthop., v.104, n.5, p.455-70, Nov. 1993. 
29. CETLIN N.M.; TEN HOEVE, A.T. Non extraction treatment. J. clin. Orthodont., v.17, n.6, p.396-404, June 1983.

30. CHEBIB F.S.; CHAMMA, A.M. Indices of craniofacial asymmetry. Angle Orthodont., v.51, n.3, p.214-25, July 1981.

31. CHENEY E.A. The influence of dentofacial asymmetries upon treatment procedures. Amer. J. Orthodont., v.38, n.2, p.934-45, July 1952.

32. CHENEY E.A. Dentofacial asymmetries and their clinical significance. Amer. J. Orthodont., v.47, n.2, p.814-29, Feb. 1961.

33. COOK J.T. Asymmetry of the cranifacial skeleton. Brit. J. Orthodont., v.7, n.1, p.33-8, Jan. 1980.

34. CRUZ K.S. Avaliação das alterações dentoesqueléticas decorrentes do tratamento da má oclusão de Classe II, subdivisão por meio das radiografias submentoniana e póstero-anterior. Bauru, 2000. 208p. Dissertação (Mestrado) - Faculdade de Odontologia de Bauru, Universidade de São Paulo.

35. DAHLBERG G. Statistical methods for medical and biological students. New York, Interscience, 1940. 
36. DAINESI E.A. A influência dos padrões extremos de crescimento da face sobre o perfil tegumentar, analisada cefalometricamente em jovens leucodermas brasileiros. Bauru, 1998. 244p. Tese (Doutorado) - Faculdade de Odontologia de Bauru, Universidade de São Paulo.

37. DI NICOLÓ R. et al. Desenvolvimento da linha média nas dentições decídua, mista e permanente. J. Bras. Ortodon. Ortop. Facial, v.5, n.28, p.67-9, 2000.

38. DIOGO E.L.; BERNARDES, L.A.A. Estudo comparativo entre a preferência estética do perfil tegumentar avaliado por ortodontistas e leigos com padrões cefalométricos existentes. R. Dental Press Ortodon. Ortop. Facial, v.8, n.5, p.49-58, set./out. 2003.

39. ENLOW D.H. Facial growth. 3 ed. Philadelphia, W.B. Saunders, 1990.

40. ENLOW D.H.; KURODA, T.; LEWIS, A.B. The morphological and morphogenetic basis for craniofacial form and pattern. Angle Orthodont., v.41, n.3, p.161-88, July 1971.

41. ERDOGAN E.; ERDOGAN, E. Asymmetric application of jasper jumper in the correction of midline discrepancies. J. clin. Orthodont., v.32, p.170-80, 1998.

42. FINK D.F.; SMITH, R.J. The duration of orthodontic treatment. Amer. J. Orthodont. Dentofac. Orthop., v.102, n.1, p.45-51, July 1992. 
43. FISMANN R.A.; VIGORITO, J.W. Estudo da estética facial em adolescentes brasileiros, leucodermas, portadores de oclusão dentária normal, empregando a análise de Burstone. Ortodontia, v.20, p.52-64, 1987.

44. FORSBERG C.T.; BURSTONE, C.J.; HANLEY, K.J. Diagnosis and treatment planning of skeletal asymmetry with the submental-vertical radiograph. Amer. J. Orthodont., v.85, n.3, p.224-37, Mar. 1984.

45. GARN S.M.; LEWIS, A.B.; KEREWSKY, R.S. The meaning of bilateral asymmetry in the permanent dentition. Angle Orthodont., v.36, n.1, p.55-62, Jan. 1966.

46. GIANELLY A.A.; PAUL, I.A.A. A procedure for midline correction. Amer. J. Orthodont., v.58, p.264-7, 1970.

47. GRABER T.M.; VANARSDALL JR, R.L. Ortodontia - princípios e técnicas atuais. 2 ed. Rio de Janeiro, Guanabara Koogan, 1996.

48. GRAVELY J.F.; BENZIES, P.M. The clinical significance of tracing error in cephalometry. Brit. J. Orthod., v.1, p.95-111, 1974.

49. HARRIS E.F.; DYER, G.S.; VADEN, J.L. Age effects on orthodontic treatment: skeletodental assessments from the Johnston analysis. Amer. J. Orthodont. Dentofac. Orthop., v.100, n.6, p.531-6, Dec. 1991.

50. HERSCHOPF S.A. Class II, division 2 malocclusion - nonextraction. Amer. J. Orthodont. Dentofac. Orthop., v.97, n.5, p.374-80, May 1990. 
51. HERSHON L.E.; GIDDON, D.B. Determinants of facial profile selfperception. Amer. J. Orthodont., v.78, n.3, p.279-95, Sept. 1980.

52. HOLDAWAY R.A. Changes in relationship of points $A$ and $B$ during orthodontic treatment. Amer. J. Orthodont., v.42, p.176-93, 1956.

53. HOLMAN J.K. et al. An assessment of extraction versus nonextraction orthodontic treatment using the peer assessment rating (PAR) index. Angle Orthodont., v.68, n.6, p.527-34, 1998.

54. HOUSTON W.J.B. The analyses of errors in orthodontic treatment. Amer. J. Orthodont., v.83, n.5, p.382-90, May 1983.

55. HUNTER W.S. Lateral asymmetries of 93 maxillary arches. Acta odont. scand., v.11, p.95-9, 1953.

56. IAGUE NETO G. Avaliação do perfil tegumentar e a sua relação com as estruturas dentoesqueléticas maxilomandibulares, em adultos jovens portadores de oclusão normal e boa estética facial. Bauru, 1998. 152p. Dissertação (Mestrado) - Faculdade de Odontologia de Bauru, Universidade de São Paulo.

57. JANSON G.R.P. Estudo tridimensional das assimetrias dentárias e esqueléticas na má oclusão de Classe II, subdivisão. Bauru, 1998. 271p. Tese (Livre-Docência) - Faculdade de Odontologia de Bauru, Universidade de São Paulo. 
58. JANSON G.R.P. et al. A assimetria dentária e suas implicações no tratamento ortodôntico: apresentação de um caso clínico. Ortodontia, v.26, n.3, p.68-73, set./dez. 1995.

59. JANSON G.R.P. et al. Three-dimensional evaluation of skeletal and dental asymmetries in Class II subdivision malocclusions. Amer. J. Orthodont. Dentofac. Orthop., v.119, n.4, p.406-18, Apr. 2001.

60. JANSON G.R.P. et al. Influência do padrão facial na decisão de extrações. R. Dental Press Ortodon. Ortop. Facial, v.7, n.2, p.41-7, mar./abr. 2002.

61. JANSON G.R.P. et al. Orthodontic treatment of subdivision cases. World J. Orthod., v.4, n.1, p.36-46, 2003.

62. JANSON G.R.P. et al. Class II subdivision treatment sucess rate with symmetric and asymmetric extraction protocols. Amer. J. Orthodont. Dentofac. Orthop., v.124, n.3, p.257-64, Sept. 2003.

63. JANSON G.R.P.; MARTINS, D.R. Análise funcional e ajuste oclusal em ortodontia: estudo clínico. Ortodontia, v.23, n.1, p.4-15, 1990.

64. JANSON G.R.P.; METAXAS, A.; WOODSIDE, D.G. Variation in maxillary and mandibular molar and incisor vertical dimension in 12 year-old subjects with excess, normal and short lower anterior face height. Amer. J. Orthodont. Dentofac. Orthop., v.106, n.4, p.409-18, Oct. 1994. 
65. JERROLD L.; LOWENSTEIN, J. The midline: diagnosis and treatment. Amer. J. Orthodont. Dentofac. Orthop., v.97, n.6, p.453-62, June 1990.

66. JOHNSTON C.D.; BURDEN, D.J.; STEVENSON, M.R. The influence of dental to facial midline discrepancies on dental atractiveness ratings. Europ. J. Orthodont., v.21, n.5, p.517-22, Oct. 1999.

67. KANTOMAA T. The relation between mandibular configuration and shape of the glenoid fossa in the human. Europ. J. Orthodont., v.11, p.7781, 1989.

68. KELLY M.F. Light-wire treatment of a class II, division 1, subdivision malocclusion - an American Board of Orthodontics case report. Amer. J. Orthodont. Dentofac. Orthop., v.89, n.3, p.216-22, Mar. 1986.

69. KOCADERELI I. Changes in soft tissue profile after orthodontic treatment with and without extractions. Amer. J. Orthodont. Dentofac. Orthop., v.122, n.1, p.67-72, July 2002.

70. KROGMAN V.M.; SASSOUNI, V. A syllabus in roentgenographic cephalometric. 2 ed. Philadelphia, College Offset, 1957.

71. LAMASTRA S.J. Relationships between changes in skeletal and integumental points $A$ and $B$ following orthodontic treatment. Amer. J. Orthodont., v.79, n.4, p.416-23, Apr. 1981.

72. LEGAN H.L. Surgical correction of patients with asymmetries. Seminars in Orthodontics, v.4, n.3, p.189-98, Sept. 1998. 
73. LEW K.K.K.; TAY, D.K.L. Submentovertex cephalometric norms in male chinese subjects. Amer. J. Orthodont. Dentofac. Orthop., v.103, n.3, p.247-52, Mar. 1993.

74. LEWIS D. The deviated midline. Amer. J. Orthodont., v.70, p.601-16, 1976.

75. LITT R.A. et al. Class II div 2 malocclusion. To extract or not to extract? Angle Orthodont., v.54, n.2, p.123-38, Apr. 1984.

76. LIVIERATOS F.A.; JOHNSTON, L.E. A comparision of one-stage and twostage nonextraction alternatives in matched class II samples. Amer. J. Orthodont. Dentofac. Orthop., v.108, n.2, p.118-31, Aug. 1995.

77. LUNDSTRÖM A. Some asymmetries of the dental arches, jaws and skull, and their etiologic significance. Amer. J. Orthodont., v.47, n.2, p.81106, Feb. 1961.

78. MARTINS D.R. et al. Atlas de crescimento craniofacial. 1 ed. Bauru, Editora Santos, 1998.

79. MARTINS de ARAÚJO T.; SCHIRMER, R.W.; ALMEIDA, M.A. Skeletal and dental arch asymmetries in class II, division 1 , subdivision malocclusions. J. clin. pediat. Dent., v.18, n.3, p.181-5, June 1994.

80. MCNAMARA JUNIOR J.A. Components of class II malocclusion in children 8-10 years of age. Angle Orthodont., v.51, n.3, p.177-202, July 1981. 
81. MCNAMARA JUNIOR J.A. A method of cephalometric evaluation. Amer. J. Orthodont., v.86, n.6, p.449-69, Dec. 1984.

82. MELNIK A.K. A cephalometric study of mandibular asymmetry in a longitudinal followed sample of growing children. Amer. J. Orthodont. Dentofac. Orthop., v.101, n.4, p.355-66, Apr. 1992.

83. MONGINI F. Remodelling of the temporomandibular condyle in the adult and its relationship to the conditions of dental arches. Acta anat., v.82, p.292-300, 1972.

84. MONGINI F.; SCHMID, W. Treatment of mandibular asymmetries during growth: a longitudinal study. Europ. J. Orthodont., v.9, n.1, p.51-67, Feb. 1987.

85. MOORE A.W. Orthodontic treatment factors in class II malocclusion. Amer. J. Orthodont., v.45, n.5, p.323-52, May 1959.

86. MOYERS R.E. et al. Differential diagnosis of a class II malocclusion (part 1). facial types associated with class II malocclusions. Amer. J. Orthodont., v.78, n.5, p.477-94, Nov. 1980.

87. OGAARD B.; KROGSTAD, O. Craniofacial structure and soft tissue profile in patients with severe hypodontia. Amer. J. Orthodont. Dentofac. Orthop., v.108, n.5, p.472-7, Nov. 1995.

88. O'REILLY B.L.; NANDA, S.K.; CLOSE, J. An evaluation of mandibular symmetry in adults with unilateral posterior crossbite. Amer. $\mathbf{J}$. Orthodont. Dentofac. Orthop., v.103, n.6, p.504-9, June 1993. 
89. PANCHERZ $H$. The nature of class II relapse after Herbst appliance treatment: a cephalometric long-term investigation. Amer. J. Orthodont. Dentofac. Orthop., v.100, n.3, p.220-33, Sept. 1991.

90. PAQUETTE D.E.; BEATTIE, J.R.; JOHNSTON JUNIOR, L.E. A long term comparison of nonextraction and premolar extraction edgewise therapy in "borderline" class II patients. Amer. J. Orthodont. Dentofac. Orthop., v.102, n.1, p.1-14, July 1992.

91. PECK H.; PECK, S. A concept of facial esthetics. Angle Orthodont., v.40, n.4, p.284-318, Oct. 1970.

92. PECK S.; PECK, L.; KATAJA, M. Skeletal asymmetry in esthetically pleasing faces. Angle Orthodont., v.6, n.1, p.43-8, 1991.

93. POLLARD L.E.; MAMANDRAS, A.H. Male postpubertal facial growth in class II malocclusions. Amer. J. Orthodont. Dentofac. Orthop., v.108, n.1, p.62-8, July 1995.

94. PONYI S.; SZABÓ, G.; NYILASI, J. Asymmetry of mandibular dimensions in european skulls. Proc. Fin. dent. Soc., v.87, n.3, p.321-7, July 1991.

95. PROCACI M.I.M.A., RAMALHO, S.A. Crescimento assimétrico da face: atividade muscular e implicações oclusais. R. Dental Press Ortodon. Ortop. Facial, v.7, n.6, p.87-93, nov./dez. 2002. 
96. PROFFIT W.R. Contemporary orthodontics. Saint Louis, C.V. Mosby, 1986.

97. PROFFIT W.R.; VIG, K.W.L.; TURVEY, T.A. Early fracture of the mandibular condyles: frequently and unsuspect cause of growth disturbances. Amer. J. Orthodont. Dentofac. Orthop., v.78, n.1, p.124, July 1980.

98. REBELLATO J. Asymmetric extractions used in the treatment of patients with asymmetries. Seminars in Orthodontics, v.4, n.3, p.180-8, Sept. 1998.

99. RICHARDSON A. A comparison of traditional and computadorized method of cephalometric analysis. Europ. J. Orthodont., v.3, p.15-20, 1981.

100. RICKETTS R.M. The influence of orthodontic treatment on facial growth and development. Angle Orthodont., v.30, p.103-33, 1960.

101. ROSE J.M. et al. Mandibular skeletal and dental asymmetry in class II subdivision malocclusions. Amer. J. Orthodont. Dentofac. Orthop., v.105, n.5, p.489-95, May 1994.

102. ROSEN M.D.; BUTCHER, E.O.; SILVERMAN, S.I. Muscle and skull development changes in dogs with induced unilateral anodontia. Oral Surg., v.3, p.672-5, Nov. 1965.

103. ROTH R.H. Functional occlusion for the orthodontist - part 3. J. clin. Orthodont., v.15, n.3, p.174-98, Mar. 1981. 
104. SAKIMA T. et al. Tratamento precoce da classe II, $1^{a}$ divisão, subdivisão.

Rev. Ass. Paul. Espec. Ortodon. Ortop. Facial, v.1, n.1, p.9-15, jan./mar. 2003.

105. SARNAS K.V. et al. Hemifacial microsomia treated with the Herbst appliance. Report of a case analyzed by means of roentgen stereometry and metallic implants. Amer. J. Orthodont., v.82, n.1, p.68-74, July 1982.

106. SATRAVAHA S.; SCHLEGEL, K.D. The significance of the integumentary profile. Amer. J. Orthodont. Dentofac. Orthop., v.92, n.5, p.422-6, Nov. 1987.

107. SCANAVINI J.R.; VIGORITO, J.W. Avaliação das alterações ortodônticas e ortopédicas resultantes da técnica de arco de canto, aplicada em maloclusões de classe II, $1^{\text {a }}$ divisão. Ortodontia, v.29, n.3, p.16-30, set./dez. 1996.

108. SCAVONE JÚNIOR H. O perfil facial tegumentar dos 13 aos 18 anos de idade: estudo cefalométrico longitudinal em jovens brasileiros leucodermas, com oclusão normal. Bauru, 1996. 217p. Tese (Doutorado) - Faculde de Odontologia de Bauru, Universidade de São Paulo.

109. SEELY D.M. An American Board of Orthodontics case report: treatment of a crowded class II malocclusion in an adult. Amer. J. Orthodont. Dentofac. Orthop., v.104, n.3, p.298-303, Sept. 1993. 
110. SEVERT T.R.; PROFFIT, W.R. The prevalence of facial asymmetry in the dentofacial deformities population in the University of North Carolina. Int. J. Adult Orthod. Orthognath. Surg., v.12, n.3, p.171-6, 1997.

111. SHAH S.M.; JOSHI, M.R. An assessment of asymmetry in the normal craniofacial complex. Angle Orthodont., v.48, n.2, p.141-7, Apr. 1978.

112. SHAW W.C. et al. The influence of dentofacial appearence on the social attractiveness of youth adults. Amer. J. Orthodont. Dentofac. Orthop., v.87, n.1, p.21-6, Jan. 1985.

113. SHEATS R.D. et al. Prevalence of orthodontic asymmetries. Seminars in Orthodontics, v.4, n.3, p.138-45, Sept. 1998.

114. SHELLEY A. et al. Asymmetric extraction treatment of an class II division 2 subdivision left malocclusion with anterior and posterior crossbites. Amer. J. Orthodont. Dentofac. Orthop., v.118, n.4, p.462-6, Oct. 2000.

115. SHROFF B.; LINDAUER, S.J.; BURSTONE, C.J. Class II subdivision treatment with tip-back moments. Europ. J. Orthodont., v.19, n.1, p.93-101, Feb. 1997.

116. SHROFF B.; SIEGEL, S.M. Treatment of patients with asymmetries using asymmetric mechanics. Seminars in Orthodontics, v.4, n.3, p.298303, Sept. 1998. 
117. SIEGEL M.A. A matter of class: interpreting subdivision in a malocclusion. Amer. J. Orthodont. Dentofac. Orthop., v.122, n.6, p.582-6, Dec. 2002.

118. SILVA M.L.A. Estudo cefalométrico semilongitudinal (fases inicial, final de tratamento e pós-contenção) de jovens brasileiras, leucodermas, tratadas ortodonticamente, portadoras inicialmente de Classe I e II divisão 1 e comparadas com as de oclusão normal. Bauru, 1986. 152p. Dissertação (Mestrado) - Faculdade de Odontologia de Bauru, Universidade de São Paulo.

119. SJURGEN R.C.; LEGAN, H.L.; WERTHER, J.R. Case report: assessment, documentation and treatment of a development facial asymmetry following early childwood injury. Angle Orthodont., v.69, n.2, p.89-94, Feb. 1999.

120. SKOLNICK J. et al. Prepubertal trauma and mandibular asymmetry in orthognatic surgery and orthodontic patients. Amer. J. Orthodont. Dentofac. Orthop., v.105, n.1, p.73-7, Jan. 1994.

121. SLAVICEK R. JCO interviews: on clinical and instrumental functional analysis for diagnosis and treatment planning - part 1 . J. clin. Orthodont., v.22, n.6, p.358-70, June 1988.

122. SMITH S.S.; ALEXANDER, R.G. Orthodontic correction of a class II division 1 subdivision right open bite malocclusion in an adolescent patient with a cervical pull face-bow headgear. Amer. J. Orthodont. Dentofac. Orthop., v.116, n.1, p.60-5, July 1999. 
123. STAGGERS J.A. A vertical changes following first premolar extractions. Amer. J. Orthodont. Dentofac. Orthop., v.105, n.1, p.19-24, Jan. 1994.

124. STEINER C.L. Cephalometrics as a clinical tool. In: KRAUS B.; RIEDEL, R., Vistas in Orthodontics. Philadelphia, Lea \& Fabiger, 1962.

125. TALLENTS R.H. et al. Angular and linear comparisons with unilateral mandibular asymmetry. J. Craniomandibular Dis. Fac. Oral Pain, v.5, n.2, p.135-41, May 1991.

126. TANAKA O.; KREIA, T.B. Em busca das linhas medianas corretas. R. Clin. Ortodon. Dental Press, v.1, n.4, p.39-49, ago./set. 2002.

127. TODD M. et al. Asymmetric extraction treatment of a Class II, division 1, subdivision left malocclusion with anterior and posterior crossbites. Amer. J. Orthodont. Dentofac. Orthop., v.115, n.4, p.410-17, Apr. 1999.

128. TULLOCH C.; PHILLIPS, C.; DANN, C. Cephalometric measures as indicators of facial attractiveness. Int. J. Adult Orthod. Orthognath. Surg., v.8, n.3, p.171-9, 1993.

129. TWEED C.H. Indication for the extraction of teeth in orthodontic procedures. Amer. J. Orthodont. oral Surg., v.30, p.405-28, 1944.

130. TWEED C.H. The Frankfort-Mandibular Incisor Angle (FMIA) in orthodontic diagnosis, treatment and prognosis. Angle Orthodont., v.24, n.3, p.121-69, July 1954. 
131. UNITED States Department of Health Education and Welfare. An assessment of the occlusion of the teeth of youths 12-17 years. Rockville, Maryland, National Center for Health Statistics, 1977.

132. VALARELLI F.P. Estabilidade a longo prazo do tratamento sem extração da mordida aberta anterior, na fase da dentadura permanente. Bauru, 2002. 121p. Dissertação (Mestrado) - Faculdade de Odontologia de Bauru, Universidade de São Paulo.

133. VAN SICKELS J.E.; LARSEN, A.J.; THRASH, W.J. A retrospective study of relapse in rigidity fixated sagital split osteotomies: contributing factors. Amer. J. Orthodont. Dentofac. Orthop., v.93, n.5, p.413-8, May 1988.

134. VERDONCK A. et al. The interaction between soft tissues and the sagital development of the dentition and the face. Amer. J. Orthodont. Dentofac. Orthop., v.104, n.4, p.342-9, Oct. 1993.

135. VIAZIS A.D. Atlas de ortodontia. Princípios e aplicações clínicas. 1 ed. São Paulo, Editora Santos, 1996.

136. VIG P.S. et al. The duration of orthodontic treatment with and without extractions: a pilot study of five selected practices. Amer. J. Orthodont. Dentofac. Orthop., v.97, n.1, p.45-51, Jan. 1990.

137. VIG P.S.; HEWITT, A.B. Asymmetry of human facial skeleton. Angle Orthodont., v.45, n.4, p.125-9, Apr. 1975. 
138. WERTZ R.A. Diagnosis and treatment planning of unilateral Class II malocclusion. Angle Orthodont., v.45, n.2, p.124-9, Apr. 1975.

139. WHOLLEY C.J.; WOODS, M.G. The effects of commonly prescribed premolar extraction sequences on the curvature of the upper and lower lips. Angle Orthodont., v.73, n.4, p.386-95, Aug. 2003.

140. WILLIAMSON E.H. JCO Interviews: on occlusion and TMJ dysfunction part 2. J. clin. Orthodont., v.15, n.6, p.393-410, June 1981.

141. WILLIAMSON E.H.; SIMMONS, M.D. Mandibular asymmetry and its relation to pain dysfunction. Amer. J. Orthodont., v.76, n.6, p.612-7, Dec. 1979.

142. WOHL T.S.; BAMONTE, E.; PEARSON, H.E. Nonextraction treatment of unilateral class II, division 1 malocclusion with asymmetric headgear. Amer. J. Orthodont. Dentofac. Orthop., v.113, n.5, p.483-7, May 1998.

143. YAILLEN D.M. Correction of mandibular asymmetric prognathism. Angle Orthodont., v.64, n.2, p.99-104, 1994.

144. ZYLINSKI C.G.; NANDA, R.S.; KAPILA, S. Analysis of the soft tissue facial profile in white males. Amer. J. Orthodont. Dentofac. Orthop., v.101, n.5, p.514-8, June 1992. 
ABSTRACT

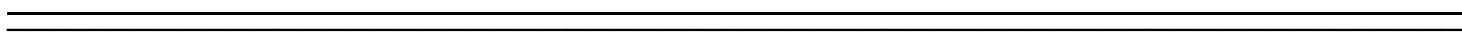




\section{ABSTRACT}

"Cephalometric evaluation of dentoskeletal and tegumental changes of symmetric and asymmetric extraction treatment of Class II, subdivision, malocclusion."

The purpose of this study was to cephalometrically evaluate dentoskeletal and tegumental changes consequent to orthodontic treatment in subjects with Angle's Class II, subdivision malocclusions, treated with asymmetric extractions, compared to symmetric extractions. The sample consist of two groups, with 58 lateral cephalometric radiographs each, initial (T1) and final (T2), from 29 patients: group 1 - Class II, subdivision subjects treated with asymmetric extraction of three bicuspids, two uppers and one lower Class I side; group 2 - Class II, subdivision subjects treated with symmetric extractions of four bicuspids, two upper and two lower. All possessed a full complement of permanent teeth including first molars, at the beginning of treatment. The average initial age of subjects was 14,28 and 13,15 years and final was 16,90 and 15,64, group 1 and 2 respectively. The differences between the observation stages in each group (T1 $\times \mathrm{T} 2)$ were analyzed with paired t tests and groups comparison of treatment changes (T2T1) were verified with independent $t$ test. Results demonstrated statistically significance differences between symmetric and asymmetric treatment changes as: less retraction of lower incisors in symmetric extraction group; less tegumental retraction in the same group; and increase of lower molar asymmetry index with asymmetric extraction, while symmetric extraction showed opposite behavior. 
TABELA A1 - Mensurações cefalométricas individuais, iniciais e finais, para o grupo 1, tratados com extrações de três pré-molares.

\begin{tabular}{|c|c|c|c|c|c|c|}
\hline \multicolumn{7}{|c|}{ JOVENS TRATADOS COM EXTRAÇÕES DE TRÊS PRÉ-MOLARES } \\
\hline \multirow[t]{2}{*}{$\mathbf{N}$} & \multicolumn{2}{|c|}{ SNA } & \multicolumn{2}{|c|}{ CO-A } & \multicolumn{2}{|c|}{ SNB } \\
\hline & INICIAL & FINAL & INICIAL & FINAL & INICIAL & FINAL \\
\hline 1 & 85,9 & 81,6 & 84,0 & 84,8 & 81,0 & 77,7 \\
\hline 2 & 81,7 & 80,7 & 84,3 & 84,9 & 75,5 & 75,0 \\
\hline 3 & 80,8 & 81,1 & 78,5 & 80,0 & 77,6 & 78,5 \\
\hline 4 & 81,6 & 82,0 & 79,7 & 80,3 & 78,6 & 77,1 \\
\hline 5 & 77,2 & 76,8 & 90,0 & 89,6 & 75,3 & 75,2 \\
\hline 6 & 81,5 & 81,2 & 78,3 & 76,4 & 78,3 & 78,8 \\
\hline 7 & 86,7 & 87,4 & 82,1 & 82,8 & 81,3 & 81,8 \\
\hline 8 & 79,4 & 78,5 & 83,4 & 84,3 & 73,3 & 73,8 \\
\hline 9 & 91,5 & 87,6 & 89,9 & 92,0 & 86,8 & 83,7 \\
\hline 10 & 83,3 & 82,9 & 88,0 & 85,1 & 75,7 & 77,1 \\
\hline 11 & 78,4 & 77,3 & 75,7 & 75,2 & 74,5 & 77,0 \\
\hline 12 & 75,6 & 75,7 & 81,2 & 82,2 & 74,1 & 76,1 \\
\hline 13 & 75,1 & 74,3 & 82,4 & 82,6 & 70,8 & 71,5 \\
\hline 14 & 83,5 & 84,8 & 87,2 & 86,5 & 78,4 & 78,9 \\
\hline 15 & 80,3 & 77,3 & 80,3 & 76,1 & 74,9 & 74,4 \\
\hline 16 & 79,8 & 81,2 & 79,3 & 83,7 & 83,9 & 82,6 \\
\hline 17 & 84,2 & 88,0 & 84,5 & 87,1 & 81,9 & 85,3 \\
\hline 18 & 83,7 & 85,8 & 89,1 & 95,0 & 79,6 & 82,4 \\
\hline 19 & 84,3 & 82,5 & 83,2 & 83,5 & 79,4 & 78,2 \\
\hline 20 & 82,4 & 81,1 & 93,5 & 94,4 & 73,6 & 75,8 \\
\hline 21 & 81,5 & 84,5 & 86,3 & 93,9 & 74,2 & 80,6 \\
\hline 22 & 85,0 & 86,0 & 91,1 & 92,1 & 75,8 & 78,0 \\
\hline 23 & 81,3 & 78,9 & 85,3 & 84,5 & 76,0 & 75,9 \\
\hline 24 & 80,6 & 79,3 & 80,2 & 81,3 & 75,2 & 74,6 \\
\hline 25 & 77,3 & 76,6 & 82,4 & 81,7 & 72,2 & 71,7 \\
\hline 26 & 82,6 & 83,5 & 85,5 & 91,9 & 82,5 & 81,6 \\
\hline 27 & 88,4 & 86,4 & 80,3 & 83,2 & 80,9 & 79,7 \\
\hline 28 & 82,0 & 81,8 & 85,4 & 83,9 & 76,2 & 77,8 \\
\hline 29 & 81,6 & 81,6 & 86,3 & 88,3 & 76,5 & 77,1 \\
\hline
\end{tabular}


TABELA A1(cont.) - Mensurações cefalométricas individuais, iniciais e finais, para o grupo 1, tratados com extrações de três pré-molares.

\begin{tabular}{|c|c|c|c|c|c|c|}
\hline \multicolumn{7}{|c|}{ JOVENS TRATADOS COM EXTRAÇÕES DE TRÊS PRÉ-MOLARES } \\
\hline \multirow[t]{2}{*}{$\mathbf{N}$} & \multicolumn{2}{|c|}{ CO-GN } & \multicolumn{2}{|c|}{ ANB } & \multicolumn{2}{|c|}{ Diff. MX-MD } \\
\hline & INICIAL & FINAL & INICIAL & FINAL & INICIAL & FINAL \\
\hline 1 & 111,1 & 113,0 & 5,0 & 3,8 & 27,1 & 28,2 \\
\hline 2 & 107,1 & 109,2 & 6,2 & 5,7 & 22,8 & 24,3 \\
\hline 3 & 103,2 & 104,9 & 3,2 & 2,6 & 24,7 & 24,9 \\
\hline 4 & 109,8 & 110,6 & 3,0 & 4,9 & 30,1 & 30,3 \\
\hline 5 & 111,2 & 112,8 & 1,9 & 1,6 & 21,2 & 23,1 \\
\hline 6 & 104,9 & 104,0 & 3,2 & 2,4 & 26,6 & 27,6 \\
\hline 7 & 105,2 & 108,6 & 5,4 & 5,6 & 23,2 & 25,9 \\
\hline 8 & 108,6 & 112,6 & 6,1 & 4,7 & 25,2 & 28,3 \\
\hline 9 & 118,1 & 123,8 & 4,7 & 3,9 & 28,2 & 31,8 \\
\hline 10 & 112,0 & 107,7 & 7,6 & 5,8 & 24,0 & 22,6 \\
\hline 11 & 100,6 & 109,7 & 3,9 & 0,3 & 24,9 & 34,6 \\
\hline 12 & 113,2 & 116,9 & 1,5 & $-0,4$ & 32,0 & 34,7 \\
\hline 13 & 100,3 & 103,4 & 4,3 & 2,8 & 17,9 & 20,8 \\
\hline 14 & 109,9 & 108,7 & 5,1 & 5,9 & 22,7 & 22,1 \\
\hline 15 & 101,6 & 100,9 & 5,4 & 2,9 & 21,2 & 24,7 \\
\hline 16 & 115,2 & 117,9 & $-4,1$ & $-1,3$ & 35,9 & 34,2 \\
\hline 17 & 109,3 & 117,6 & 2,3 & 2,7 & 24,9 & 30,5 \\
\hline 18 & 113,4 & 124,8 & 4,1 & 3,4 & 24,3 & 29,7 \\
\hline 19 & 116,6 & 118,7 & 4,9 & 4,3 & 33,4 & 35,3 \\
\hline 20 & 122,1 & 131,7 & 8,7 & 5,4 & 28,6 & 37,3 \\
\hline 21 & 100,9 & 116,7 & 7,3 & 3,8 & 14,6 & 22,9 \\
\hline 22 & 110,0 & 115,1 & 9,2 & 8,0 & 18,9 & 23,1 \\
\hline 23 & 109,9 & 112,0 & 5,3 & 3,0 & 24,6 & 27,6 \\
\hline 24 & 108,9 & 112,0 & 5,5 & 4,7 & 28,7 & 30,7 \\
\hline 25 & 105,5 & 105,9 & 5,1 & 4,9 & 23,1 & 24,2 \\
\hline 26 & 114,3 & 120,4 & 0,1 & 1,9 & 28,8 & 28,5 \\
\hline 27 & 107,2 & 116,0 & 7,5 & 6,8 & 27,0 & 32,8 \\
\hline 28 & 107,6 & 110,9 & 5,8 & 4,0 & 22,2 & 27,0 \\
\hline 29 & 113,7 & 117,4 & 5,0 & 4,6 & 27,4 & 29,1 \\
\hline
\end{tabular}


TABELA A1(cont.) - Mensurações cefalométricas individuais, iniciais e finais, para o grupo 1, tratados com extrações de três pré-molares.

\begin{tabular}{ccccccc}
\hline \multicolumn{6}{c}{ JOVENS TRATADOS COM EXTRAÇÕES DE TRÊS PRÉ-MOLARES } \\
\hline \multirow{2}{*}{$\mathbf{N}$} & \multicolumn{2}{c}{ SN.GoGN } & \multicolumn{3}{c}{ FMA } & \multicolumn{3}{c}{ AFAI } \\
\cline { 2 - 7 } & INICIAL & FINAL & INICIAL & FINAL & INICIAL & FINAL \\
\hline 1 & 28,8 & 31,9 & 25,8 & 25,9 & 65,9 & 67,6 \\
2 & 34,2 & 33,7 & 29,5 & 26,3 & 65,9 & 70,9 \\
3 & 35,6 & 34,5 & 28,5 & 26,5 & 63,7 & 62,6 \\
4 & 35,1 & 35,9 & 30,8 & 30,7 & 70,3 & 70,2 \\
$\mathbf{5}$ & 31,1 & 29,5 & 24,4 & 21,8 & 64,4 & 65,2 \\
6 & 31,9 & 30,4 & 24,1 & 23,7 & 61,1 & 61,0 \\
7 & 35,3 & 35,6 & 36,7 & 32,0 & 63,9 & 66,9 \\
8 & 33,4 & 34,1 & 23,4 & 21,8 & 68,0 & 70,9 \\
9 & 27,9 & 31,6 & 22,2 & 23,0 & 74,1 & 73,8 \\
10 & 39,9 & 37,3 & 31,4 & 31,4 & 65,7 & 63,4 \\
11 & 32,6 & 30,3 & 23,3 & 22,8 & 61,9 & 66,1 \\
12 & 30,6 & 27,8 & 19,0 & 22,3 & 65,8 & 66,9 \\
13 & 36,2 & 35,7 & 26,1 & 25,5 & 58,5 & 60,7 \\
14 & 32,7 & 30,2 & 26,9 & 26,3 & 65,9 & 67,6 \\
15 & 36,2 & 37,0 & 27,9 & 27,9 & 58,7 & 62,9 \\
16 & 32,0 & 33,3 & 30,3 & 30,9 & 61,9 & 63,4 \\
17 & 31,5 & 30,1 & 25,7 & 26,1 & 58,0 & 64,5 \\
18 & 24,6 & 20,1 & 18,3 & 12,8 & 64,1 & 68,0 \\
19 & 37,3 & 37,7 & 28,1 & 30,2 & 73,3 & 77,2 \\
$\mathbf{2 0}$ & 40,0 & 37,2 & 29,8 & 26,9 & 74,9 & 83,2 \\
$\mathbf{2 1}$ & 33,8 & 28,1 & 22,1 & 17,6 & 57,0 & 59,5 \\
$\mathbf{2 2}$ & 31,8 & 28,4 & 24,4 & 22,7 & 67,7 & 71,8 \\
$\mathbf{2 3}$ & 30,8 & 32,6 & 21,9 & 23,9 & 63,1 & 66,1 \\
$\mathbf{2 4}$ & 35,3 & 35,5 & 30,4 & 26,4 & 69,2 & 71,1 \\
$\mathbf{2 5}$ & 42,4 & 40,5 & 36,9 & 37,8 & 75,0 & 78,5 \\
$\mathbf{2 6}$ & 24,5 & 23,4 & 20,8 & 17,7 & 66,3 & 66,4 \\
$\mathbf{2 7}$ & 35,3 & 39,3 & 31,8 & 31,1 & 70,4 & 76,0 \\
$\mathbf{2 8}$ & 25,7 & 23,0 & 17,8 & 14,2 & 56,1 & 58,9 \\
$\mathbf{2 9}$ & 34,0 & 31,6 & 26,0 & 22,4 & 70,8 & 70,7 \\
\hline
\end{tabular}


TABELA A1(cont.) - Mensurações cefalométricas individuais, iniciais e finais, para o grupo 1, tratados com extrações de três pré-molares.

\begin{tabular}{|c|c|c|c|c|c|c|}
\hline \multicolumn{7}{|c|}{ JOVENS TRATADOS COM EXTRAÇÕES DE TRÊS PRÉ-MOLARES } \\
\hline \multirow[t]{2}{*}{$\mathbf{N}$} & \multicolumn{2}{|c|}{ U6-PTV } & \multicolumn{2}{|c|}{ U6-PP } & \multicolumn{2}{|c|}{ L6-PTV } \\
\hline & INICIAL & FINAL & INICIAL & FINAL & INICIAL & FINAL \\
\hline 1 & 15,1 & 20,0 & 23,4 & 25,3 & 13,9 & 17,8 \\
\hline 2 & 10,5 & 16,8 & 20,3 & 24,2 & 8,1 & 14,8 \\
\hline 3 & 19,1 & 24,3 & 25,3 & 24,7 & 16,9 & 21,1 \\
\hline 4 & 14,4 & 15,6 & 22,8 & 23,4 & 12,6 & 13,5 \\
\hline 5 & 14,8 & 21,0 & 22,5 & 23,3 & 15,4 & 17,8 \\
\hline 6 & 14,4 & 14,9 & 23,1 & 24,3 & 14,0 & 14,4 \\
\hline 7 & 13,3 & 22,7 & 21,7 & 25,7 & 12,2 & 21,7 \\
\hline 8 & 15,9 & 19,6 & 26,4 & 27,7 & 14,4 & 18,4 \\
\hline 9 & 24,5 & 26,5 & 28,2 & 27,4 & 25,4 & 26,5 \\
\hline 10 & 15,3 & 17,4 & 23,4 & 20,2 & 13,2 & 15,2 \\
\hline 11 & 14,3 & 13,7 & 22,9 & 25,6 & 12,2 & 11,9 \\
\hline 12 & 14,1 & 11,9 & 26,1 & 27,3 & 11,6 & 10,2 \\
\hline 13 & 16,1 & 17,3 & 19,5 & 21,1 & 14,0 & 15,0 \\
\hline 14 & 16,6 & 9,9 & 24,4 & 25,2 & 16,8 & 10,0 \\
\hline 15 & 13,1 & 18,2 & 20,0 & 24,2 & 11,4 & 16,1 \\
\hline 16 & 20,0 & 20,6 & 24,9 & 24,4 & 18,5 & 20,4 \\
\hline 17 & 19,7 & 26,9 & 21,8 & 23,0 & 18,1 & 27,7 \\
\hline 18 & 16,8 & 22,3 & 21,3 & 26,0 & 15,5 & 21,6 \\
\hline 19 & 21,9 & 23,3 & 27,6 & 28,5 & 21,8 & 18,7 \\
\hline 20 & 17,4 & 25,0 & 28,3 & 33,1 & 16,0 & 24,0 \\
\hline 21 & 17,5 & 31,9 & 19,4 & 22,7 & 15,1 & 30,3 \\
\hline 22 & 21,6 & 25,2 & 23,1 & 26,6 & 19,9 & 23,8 \\
\hline 23 & 19,1 & 19,2 & 24,0 & 26,0 & 18,5 & 17,6 \\
\hline 24 & 6,7 & 14,4 & 24,5 & 26,0 & 5,9 & 13,4 \\
\hline 25 & 12,8 & 16,7 & 28,6 & 31,2 & 11,6 & 14,4 \\
\hline 26 & 17,2 & 21,2 & 26,1 & 25,3 & 15,1 & 18,7 \\
\hline 27 & 12,7 & 18,7 & 24,3 & 26,9 & 11,4 & 17,8 \\
\hline 28 & 12,4 & 19,0 & 20,3 & 20,9 & 12,5 & 18,3 \\
\hline 29 & 15,3 & 21,4 & 25,7 & 26,2 & 14,7 & 20,0 \\
\hline
\end{tabular}


TABELA A1(cont.) - Mensurações cefalométricas individuais, iniciais e finais, para o grupo 1, tratados com extrações de três pré-molares.

\begin{tabular}{|c|c|c|c|c|c|c|}
\hline \multicolumn{7}{|c|}{ JOVENS TRATADOS COM EXTRAÇÕES DE TRÊS PRÉ-MOLARES } \\
\hline \multirow[t]{2}{*}{$\mathbf{N}$} & \multicolumn{2}{|c|}{ L6-PM } & \multicolumn{2}{|c|}{ 1.NA } & \multicolumn{2}{|c|}{ 1-NA } \\
\hline & INICIAL & FINAL & INICIAL & FINAL & INICIAL & FINAL \\
\hline 1 & 30,2 & 32,2 & 17,5 & 22,5 & 1,3 & 1,4 \\
\hline 2 & 29,3 & 33,5 & 8,7 & 25,2 & 0,9 & 1,7 \\
\hline 3 & 28,1 & 30,3 & 30,6 & 32,4 & 5,1 & 4,7 \\
\hline 4 & 34,9 & 35,6 & 43,5 & 22,2 & 11,8 & 2,3 \\
\hline 5 & 30,5 & 31,1 & 38,6 & 39,1 & 8,7 & 5,8 \\
\hline 6 & 26,5 & 27,4 & 28,9 & 17,6 & 5,8 & 2,0 \\
\hline 7 & 26,9 & 29,9 & 24,3 & 18,1 & 4,2 & 2,7 \\
\hline 8 & 31,4 & 33,1 & 42,0 & 14,2 & 8,8 & 1,0 \\
\hline 9 & 30,8 & 33,4 & 20,8 & 21,8 & 3,2 & 2,9 \\
\hline 10 & 30,1 & 32,7 & 13,0 & 17,5 & 1,1 & 0,4 \\
\hline 11 & 27,1 & 29,7 & 22,8 & 25,8 & 4,7 & 6,6 \\
\hline 12 & 27,5 & 30,0 & 13,4 & 28,8 & 2,4 & 4,9 \\
\hline 13 & 29,7 & 31,7 & 26,7 & 30,7 & 5,3 & 5,0 \\
\hline 14 & 30,1 & 28,1 & 32,4 & 22,9 & 7,9 & 2,5 \\
\hline 15 & 25,4 & 28,0 & 32,3 & 37,8 & 6,2 & 4,6 \\
\hline 16 & 26,8 & 28,7 & 29,4 & 36,4 & 7,4 & 8,8 \\
\hline 17 & 27,0 & 33,6 & 30,0 & 25,1 & 5,5 & 3,8 \\
\hline 18 & 33,4 & 35,3 & 26,8 & 27,9 & 6,9 & 5,7 \\
\hline 19 & 32,1 & 34,2 & 30,4 & 18,3 & 5,6 & 2,0 \\
\hline 20 & 33,1 & 39,0 & 20,2 & 10,6 & 2,7 & 2,2 \\
\hline 21 & 25,5 & 30,9 & 33,7 & 26,4 & 8,0 & 5,5 \\
\hline 22 & 34,5 & 36,7 & 18,7 & 14,9 & 3,4 & 1,1 \\
\hline 23 & 30,0 & 31,1 & 19,4 & 20,1 & 3,3 & 2,7 \\
\hline 24 & 30,2 & 32,6 & 15,9 & 16,2 & 2,2 & 0,4 \\
\hline 25 & 33,1 & 35,6 & 32,7 & 12,9 & 7,0 & 0,6 \\
\hline 26 & 30,4 & 32,4 & 36,0 & 22,7 & 11,9 & 4,8 \\
\hline 27 & 29,4 & 32,1 & 26,0 & 21,0 & 6,2 & 1,8 \\
\hline 28 & 29,0 & 32,2 & 8,0 & 25,4 & $-0,9$ & 2,1 \\
\hline 29 & 33,9 & 34,5 & 23,1 & 19,1 & 5,8 & 2,0 \\
\hline
\end{tabular}


TABELA A1(cont.) - Mensurações cefalométricas individuais, iniciais e finais, para o grupo 1, tratados com extrações de três pré-molares.

\begin{tabular}{ccccccc}
\hline \multicolumn{5}{c}{ JOVENS TRATADOS COM EXTRAÇÕES DE TRÊS PRÉ-MOLARES } \\
\hline \multicolumn{2}{c}{$\mathbf{N}$} & \multicolumn{2}{c}{ 1.PP } & \multicolumn{2}{c}{ 1-Aperp } & \multicolumn{2}{c}{ 1-PP } \\
\cline { 2 - 7 } & INICIAL & FINAL & INICIAL & FINAL & INICIAL & FINAL \\
\hline 1 & 107,3 & 113,7 & 1,6 & 1,2 & 28,6 & 28,0 \\
2 & 93,9 & 111,6 & $-0,1$ & 1,8 & 30,7 & 29,8 \\
3 & 125,8 & 126,4 & 5,9 & 5,3 & 26,1 & 23,9 \\
4 & 133,5 & 113,5 & 11,0 & 2,3 & 24,9 & 27,0 \\
5 & 122,6 & 121,1 & 6,9 & 4,8 & 28,6 & 28,0 \\
6 & 117,8 & 106,4 & 5,9 & 1,7 & 26,5 & 27,6 \\
7 & 115,0 & 111,0 & 3,5 & 4,2 & 27,9 & 29,2 \\
8 & 132,3 & 103,6 & 8,8 & 1,2 & 25,3 & 29,9 \\
9 & 110,9 & 112,1 & 6,8 & 5,8 & 32,4 & 30,7 \\
10 & 110,5 & 114,5 & 2,7 & 1,0 & 27,4 & 25,3 \\
11 & 106,2 & 109,4 & 3,6 & 4,1 & 28,4 & 29,3 \\
12 & 96,5 & 112,8 & 1,4 & 1,9 & 29,4 & 28,2 \\
13 & 116,1 & 119,6 & 4,7 & 4,1 & 25,2 & 24,8 \\
14 & 125,3 & 115,3 & 8,5 & 3,2 & 28,8 & 28,6 \\
15 & 120,6 & 126,9 & 6,2 & 4,1 & 24,1 & 24,2 \\
16 & 119,1 & 128,8 & 5,3 & 8,0 & 25,3 & 23,3 \\
17 & 125,9 & 122,5 & 6,2 & 5,0 & 22,0 & 24,1 \\
18 & 115,2 & 119,2 & 7,6 & 7,2 & 27,8 & 26,4 \\
19 & 122,4 & 109,9 & 7,2 & 3,0 & 26,5 & 31,2 \\
20 & 116,1 & 103,6 & 4,2 & 3,2 & 29,3 & 35,9 \\
21 & 124,8 & 122,3 & 9,7 & 7,7 & 27,0 & 23,0 \\
22 & 111,5 & 108,8 & 4,6 & 2,2 & 29,5 & 30,0 \\
23 & 112,3 & 110,3 & 4,0 & 2,0 & 28,1 & 27,5 \\
24 & 105,4 & 105,3 & 0,3 & 0,1 & 30,1 & 29,0 \\
25 & 121,3 & 100,7 & 5,4 & $-1,5$ & 30,8 & 36,5 \\
26 & 123,0 & 110,8 & 10,9 & 5,3 & 30,7 & 30,9 \\
27 & 116,9 & 111,6 & 7,9 & 3,7 & 30,4 & 30,1 \\
$\mathbf{2 8}$ & 101,1 & 117,1 & $-0,9$ & 2,5 & 24,3 & 23,0 \\
$\mathbf{2 9}$ & 113,4 & 108,9 & 5,7 & 2,9 & 29,7 & 29,2 \\
\hline
\end{tabular}


TABELA A1(cont.) - Mensurações cefalométricas individuais, iniciais e finais, para o grupo 1, tratados com extrações de três pré-molares.

\begin{tabular}{|c|c|c|c|c|c|c|}
\hline \multicolumn{7}{|c|}{ JOVENS TRATADOS COM EXTRAÇÕES DE TRÊS PRÉ-MOLARES } \\
\hline \multirow{2}{*}{$\mathbf{N}$} & \multicolumn{2}{|c|}{$1 . \mathrm{NB}$} & \multicolumn{2}{|c|}{$1-\mathrm{NB}$} & \multicolumn{2}{|c|}{ 1.PM } \\
\hline & INICIAL & FINAL & INICIAL & FINAL & INICIAL & FINAL \\
\hline 1 & 27,8 & 22,3 & 3,4 & 4,5 & 96,0 & 90,3 \\
\hline 2 & 33,5 & 33,0 & 6,4 & 7,4 & 101,8 & 101,9 \\
\hline 3 & 30,0 & 27,2 & 6,6 & 5,6 & 93,6 & 90,9 \\
\hline 4 & 31,1 & 26,7 & 5,8 & 4,8 & 94,5 & 90,4 \\
\hline 5 & 19,4 & 26,6 & 3,3 & 4,0 & 91,5 & 99,7 \\
\hline 6 & 29,2 & 30,4 & 2,4 & 2,9 & 97,0 & 99,2 \\
\hline 7 & 38,3 & 29,8 & 6,6 & 8,1 & 99,6 & 89,7 \\
\hline 8 & 29,0 & 22,8 & 7,0 & 5,2 & 100,5 & 92,4 \\
\hline 9 & 25,4 & 19,0 & 6,8 & 5,7 & 88,4 & 81,6 \\
\hline 10 & 30,8 & 31,7 & 6,1 & 5,0 & 92,9 & 94,3 \\
\hline 11 & 22,9 & 21,5 & 5,1 & 3,5 & 94,2 & 92,9 \\
\hline 12 & 15,1 & 17,8 & 0,8 & 1,5 & 88,8 & 92,0 \\
\hline 13 & 31,4 & 24,0 & 7,4 & 5,9 & 101,7 & 93,8 \\
\hline 14 & 40,2 & 41,4 & 9,1 & 8,5 & 106,4 & 108,4 \\
\hline 15 & 27,9 & 28,0 & 5,9 & 5,4 & 95,0 & 94,5 \\
\hline 16 & 23,3 & 26,1 & 5,1 & 4,0 & 84,4 & 87,0 \\
\hline 17 & 23,9 & 21,1 & 5,2 & 3,7 & 88,2 & 83,6 \\
\hline 18 & 28,9 & 29,6 & 5,6 & 6,2 & 102,3 & 104,3 \\
\hline 19 & 30,9 & 27,5 & 5,6 & 6,1 & 92,0 & 89,6 \\
\hline 20 & 38,7 & 32,1 & 9,8 & 8,9 & 102,5 & 97,1 \\
\hline 21 & 36,5 & 36,0 & 8,3 & 7,3 & 105,8 & 105,4 \\
\hline 22 & 36,3 & 35,0 & 10,3 & 10,2 & 106,8 & 105,5 \\
\hline 23 & 32,4 & 21,7 & 6,0 & 3,5 & 103,7 & 91,2 \\
\hline 24 & 32,5 & 26,0 & 6,3 & 4,3 & 100,5 & 94,0 \\
\hline 25 & 28,3 & 29,0 & 5,3 & 5,1 & 91,7 & 93,5 \\
\hline 26 & 39,8 & 35,0 & 6,7 & 5,0 & 110,6 & 107,0 \\
\hline 27 & 29,1 & 30,9 & 6,9 & 9,1 & 90,3 & 89,8 \\
\hline 28 & 21,1 & 28,1 & 2,9 & 3,6 & 97,7 & 106,3 \\
\hline 29 & 33,0 & 31,7 & 7,4 & 6,3 & 100,3 & 100,3 \\
\hline
\end{tabular}


TABELA A1(cont.) - Mensurações cefalométricas individuais, iniciais e finais, para o grupo 1, tratados com extrações de três pré-molares.

\begin{tabular}{|c|c|c|c|c|c|c|}
\hline \multicolumn{7}{|c|}{ JOVENS TRATADOS COM EXTRAÇÕES DE TRÊS PRÉ-MOLARES } \\
\hline \multirow[t]{2}{*}{$\mathbf{N}$} & \multicolumn{2}{|c|}{ 1-Bperp } & \multicolumn{2}{|c|}{ 1-PM } & \multicolumn{2}{|c|}{ H.NB } \\
\hline & INICIAL & FINAL & INICIAL & FINAL & INICIAL & FINAL \\
\hline 1 & 4,7 & 6,1 & 39,0 & 40,7 & 11,5 & 8,5 \\
\hline 2 & 9,4 & 9,6 & 38,4 & 40,9 & 14,4 & 16,1 \\
\hline 3 & 6,9 & 5,8 & 39,0 & 39,4 & 13,0 & 9,0 \\
\hline 4 & 7,7 & 6,4 & 44,5 & 43,5 & 12,2 & 10,9 \\
\hline 5 & 5,7 & 5,3 & 39,5 & 38,5 & 11,8 & 10,1 \\
\hline 6 & 3,1 & 3,6 & 35,2 & 34,3 & 11,5 & 10,4 \\
\hline 7 & 8,5 & 8,8 & 36,1 & 38,9 & 15,7 & 17,9 \\
\hline 8 & 9,3 & 6,8 & 40,9 & 40,7 & 15,6 & 10,5 \\
\hline 9 & 5,2 & 4,0 & 43,1 & 43,4 & 15,5 & 14,0 \\
\hline 10 & 7,4 & 6,3 & 38,7 & 39,6 & 15,9 & 11,1 \\
\hline 11 & 7,6 & 6,0 & 36,6 & 38,4 & 13,7 & 11,0 \\
\hline 12 & 2,0 & 4,1 & 36,7 & 38,4 & 4,8 & 0,5 \\
\hline 13 & 9,3 & 8,1 & 35,9 & 37,2 & 18,0 & 16,4 \\
\hline 14 & 10,1 & 9,5 & 41,1 & 39,8 & 20,4 & 16,5 \\
\hline 15 & 7,8 & 7,0 & 37,0 & 38,6 & 24,1 & 19,9 \\
\hline 16 & 5,7 & 4,4 & 40,8 & 40,2 & 8,0 & 11,8 \\
\hline 17 & 5,2 & 3,5 & 37,2 & 40,7 & 8,2 & 5,7 \\
\hline 18 & 6,5 & 5,9 & 42,8 & 44,3 & 16,7 & 14,0 \\
\hline 19 & 5,7 & 6,7 & 40,5 & 43,8 & 9,9 & 10,6 \\
\hline 20 & 11,5 & 10,3 & 44,0 & 47,7 & 16,6 & 9,7 \\
\hline 21 & 9,2 & 6,5 & 34,5 & 39,2 & 24,2 & 20,5 \\
\hline 22 & 12,6 & 12,2 & 43,6 & 44,4 & 17,7 & 13,5 \\
\hline 23 & 7,0 & 5,0 & 37,9 & 39,3 & 13,7 & 10,1 \\
\hline 24 & 9,9 & 6,5 & 41,7 & 41,5 & 9,8 & 10,0 \\
\hline 25 & 8,5 & 8,1 & 41,1 & 42,9 & 10,1 & 9,5 \\
\hline 26 & 7,4 & 5,2 & 37,1 & 37,4 & 15,6 & 11,0 \\
\hline 27 & 8,1 & 9,8 & 41,3 & 44,4 & 19,7 & 17,0 \\
\hline 28 & 5,2 & 4,5 & 36,6 & 38,1 & 12,2 & 8,0 \\
\hline 29 & 9,3 & 6,9 & 42,2 & 41,3 & 13,0 & 11,0 \\
\hline
\end{tabular}


TABELA A1(cont.) - Mensurações cefalométricas individuais, iniciais e finais, para o grupo 1, tratados com extrações de três pré-molares.

\begin{tabular}{|c|c|c|c|c|c|c|}
\hline \multicolumn{7}{|c|}{ JOVENS TRATADOS COM EXTRAÇÕES DE TRÊS PRÉ-MOLARES } \\
\hline \multirow{2}{*}{$\mathbf{N}$} & \multicolumn{2}{|c|}{$\mathrm{H}-\mathrm{Nariz}$} & \multicolumn{2}{|c|}{ H-Li } & \multicolumn{2}{|c|}{ Ass. MX } \\
\hline & INICIAL & FINAL & INICIAL & FINAL & INICIAL & FINAL \\
\hline 1 & 3,8 & 7,1 & 1,2 & 1,8 & 2,8 & 1,1 \\
\hline 2 & 2,7 & 1,0 & 0,9 & 1,6 & 0,4 & 0,3 \\
\hline 3 & $-2,9$ & 1,1 & 2,6 & 3,8 & 3,0 & 2,4 \\
\hline 4 & 0,4 & 4,0 & 2,3 & 2,3 & 1,1 & 0,0 \\
\hline 5 & 5,6 & 7,7 & 2,4 & 1,8 & 1,7 & 1,6 \\
\hline 6 & 5,0 & 6,1 & $-1,5$ & $-0,7$ & 3,3 & 2,4 \\
\hline 7 & 3,3 & 2,0 & 2,8 & 3,0 & 2,5 & 3,5 \\
\hline 8 & 2,4 & 7,9 & 1,8 & 1,4 & 2,1 & 3,8 \\
\hline 9 & 0,4 & 1,6 & 2,8 & 3,4 & 2,7 & 3,4 \\
\hline 10 & 1,5 & 6,2 & $-0,3$ & $-1,5$ & 0,2 & 0,7 \\
\hline 11 & 2,3 & 6,6 & 2,0 & 0,3 & 1,6 & 2,1 \\
\hline 12 & 8,0 & 11,8 & $-1,4$ & $-0,8$ & 2,0 & 4,2 \\
\hline 13 & 0,5 & 2,7 & 3,4 & 4,4 & 4,0 & 3,4 \\
\hline 14 & $-4,8$ & $-2,4$ & 4,9 & 3,7 & 3,0 & 4,7 \\
\hline 15 & $-7,2$ & $-1,3$ & 4,5 & 1,6 & 1,7 & 4,0 \\
\hline 16 & 3,1 & $-0,6$ & 4,4 & 2,1 & 2,3 & 3,6 \\
\hline 17 & 5,4 & 7,3 & $-0,1$ & $-0,3$ & 4,1 & 4,5 \\
\hline 18 & $-2,4$ & 3,9 & 1,2 & 0,3 & 0,0 & 0,0 \\
\hline 19 & 7,4 & 7,6 & 0,1 & 1,0 & 4,0 & 3,2 \\
\hline 20 & 1,3 & 9,7 & 0,3 & 0,3 & 0,1 & 0,1 \\
\hline 21 & $-5,7$ & 1,5 & 2,9 & 1,7 & 2,1 & 2,8 \\
\hline 22 & 1,7 & 7,3 & 2,6 & 3,1 & 3,9 & 2,6 \\
\hline 23 & 3,3 & 8,3 & 0,0 & 0,1 & 2,4 & 2,3 \\
\hline 24 & 5,0 & 6,0 & $-0,6$ & $-1,4$ & 0,7 & 0,9 \\
\hline 25 & 6,3 & 7,6 & 2,9 & 3,1 & 3,4 & 3,6 \\
\hline 26 & $-0,6$ & 4,1 & 2,8 & 2,1 & 3,3 & 2,3 \\
\hline 27 & $-2,6$ & 1,5 & 2,9 & 4,2 & 2,9 & 4,9 \\
\hline 28 & 5,4 & 10,2 & $-0,2$ & $-1,9$ & 0,3 & 1,2 \\
\hline 29 & 2,7 & 5,3 & 0,9 & 0,5 & 0,0 & 3,1 \\
\hline
\end{tabular}


TABELA A1(cont.) - Mensurações cefalométricas individuais, iniciais e finais, para o grupo 1, tratados com extrações de três pré-molares.

\begin{tabular}{|c|c|c|c|c|c|c|}
\hline \multicolumn{7}{|c|}{ JOVENS TRATADOS COM EXTRAÇÕES DE TRÊS PRÉ-MOLARES } \\
\hline \multirow[t]{2}{*}{$\mathbf{N}$} & \multicolumn{2}{|c|}{ Ass. MD } & \multicolumn{2}{|c|}{ Ass. U6 } & \multicolumn{2}{|c|}{ Ass. L6 } \\
\hline & INICIAL & FINAL & INICIAL & FINAL & INICIAL & FINAL \\
\hline 1 & 1,2 & 0,2 & 0,0 & 0,0 & 4,3 & 5,5 \\
\hline 2 & 2,7 & 4,1 & 1,0 & 0,0 & 3,3 & 4,5 \\
\hline 3 & 1,7 & 1,2 & 2,3 & 2,4 & 1,4 & 7,6 \\
\hline 4 & 0,6 & 0,9 & 0,0 & 0,0 & 3,5 & 5,2 \\
\hline 5 & 1,4 & 2,3 & 2,2 & 3,3 & 1,0 & 4,8 \\
\hline 6 & 1,6 & 1,9 & 2,3 & 3,3 & 1,4 & 1,6 \\
\hline 7 & 1,8 & 2,4 & 2,1 & 2,5 & 1,1 & 3,8 \\
\hline 8 & 1,2 & 1,5 & 0,0 & 1,0 & 2,1 & 4,5 \\
\hline 9 & 0,5 & 0,6 & 3,2 & 2,7 & 2,0 & 0,0 \\
\hline 10 & 4,7 & 4,7 & 1,8 & 0,0 & 2,7 & 4,7 \\
\hline 11 & 0,0 & 0,0 & 1,3 & 0,0 & 2,7 & 4,9 \\
\hline 12 & 2,0 & 2,9 & 0,0 & 0,1 & 3,6 & 5,2 \\
\hline 13 & 3,2 & 0,8 & 2,2 & 2,4 & 1,5 & 2,1 \\
\hline 14 & 1,5 & 1,7 & 2,1 & 1,6 & 1,7 & 3,2 \\
\hline 15 & 0,8 & 1,7 & 1,9 & 1,6 & 2,0 & 4,6 \\
\hline 16 & 1,2 & 1,3 & 5,1 & 2,8 & 0,8 & 2,2 \\
\hline 17 & 0,0 & 1,4 & 5,0 & 5,8 & 0,0 & 0,0 \\
\hline 18 & 1,9 & 1,8 & 2,8 & 3,1 & 2,4 & 1,6 \\
\hline 19 & 2,9 & 3,8 & 2,2 & 2,5 & 1,9 & 1,3 \\
\hline 20 & 0,3 & 0,1 & 2,5 & 2,5 & 2,4 & 5,4 \\
\hline 21 & 1,3 & 1,8 & 0,0 & 2,1 & 4,5 & 3,0 \\
\hline 22 & 3,2 & 1,3 & 1,8 & 2,0 & 3,1 & 2,9 \\
\hline 23 & 1,8 & $-0,7$ & 0,0 & 0,0 & 2,6 & 4,1 \\
\hline 24 & 2,6 & 1,5 & 1,4 & 1,5 & 2,1 & 3,4 \\
\hline 25 & 1,0 & 3,2 & 3,2 & 1,7 & 1,4 & 3,3 \\
\hline 26 & 0,8 & 2,3 & 3,7 & 4,1 & 0,0 & 1,8 \\
\hline 27 & 0,3 & 0,5 & 3,2 & 1,7 & 1,1 & 4,7 \\
\hline 28 & 0,3 & 2,5 & 2,4 & 2,7 & 1,4 & 1,8 \\
\hline 29 & 3,2 & 1,0 & 1,7 & 1,9 & 2,1 & 3,8 \\
\hline
\end{tabular}


TABELA A1(cont.) - Mensurações cefalométricas individuais, iniciais e finais, para o grupo 1, tratados com extrações de três pré-molares.

\begin{tabular}{ccccccc}
\hline \multicolumn{6}{c}{ JOVENS TRATADOS COM EXTRAÇÕES DE TRÊS PRÉ-MOLARES } \\
\hline \multicolumn{2}{c}{$\mathbf{N}$} & \multicolumn{2}{c}{ Ass. Or } & \multicolumn{2}{c}{ Ass. Ptm } & \multicolumn{2}{c}{ Ass. AGo } \\
\cline { 2 - 6 } & INICIAL & FINAL & INICIAL & FINAL & INICIAL & FINAL \\
\hline $\mathbf{1}$ & 5,6 & 2,2 & 0,0 & 0,0 & 0,0 & 1,2 \\
$\mathbf{2}$ & 0,2 & 0,0 & 0,6 & 0,6 & 0,0 & 5,4 \\
$\mathbf{3}$ & 4,0 & 3,6 & 2,0 & 1,2 & 3,2 & 2,2 \\
$\mathbf{4}$ & 2,0 & 0,0 & 0,1 & 0,0 & 0,0 & 1,4 \\
$\mathbf{5}$ & 3,4 & 3,2 & 0,0 & 0,0 & 3,0 & 4,2 \\
$\mathbf{6}$ & 6,1 & 4,3 & 0,5 & 0,4 & 0,0 & 3,7 \\
$\mathbf{7}$ & 4,5 & 5,9 & 0,5 & 1,1 & 3,0 & 4,0 \\
$\mathbf{8}$ & 2,8 & 5,7 & 1,3 & 1,8 & 4,7 & 2,3 \\
$\mathbf{9}$ & 5,3 & 6,8 & 0,1 & 0,0 & 0,0 & 0,1 \\
$\mathbf{1 0}$ & 0,0 & 0,0 & 0,4 & 1,3 & 6,3 & 7,2 \\
$\mathbf{1 1}$ & 2,2 & 3,5 & 0,9 & 0,7 & 0,0 & 0,0 \\
$\mathbf{1 2}$ & 4,0 & 6,1 & 0,0 & 2,3 & 1,2 & 1,4 \\
$\mathbf{1 3}$ & 5,5 & 5,3 & 2,4 & 1,4 & 6,8 & 0,0 \\
$\mathbf{1 4}$ & 5,2 & 7,5 & 0,8 & 1,8 & 2,0 & 2,8 \\
$\mathbf{1 5}$ & 3,3 & 6,2 & 0,0 & 1,8 & 2,5 & 2,2 \\
$\mathbf{1 6}$ & 2,8 & 5,1 & 1,8 & 2,0 & 1,9 & 1,3 \\
$\mathbf{1 7}$ & 6,8 & 6,1 & 1,4 & 2,8 & 0,0 & 2,3 \\
$\mathbf{1 8}$ & 0,0 & 0,0 & 0,0 & 0,0 & 3,8 & 2,5 \\
$\mathbf{1 9}$ & 6,4 & 5,9 & 1,5 & 0,4 & 3,0 & 4,5 \\
$\mathbf{2 0}$ & 0,1 & 0,0 & 0,0 & 0,1 & 0,1 & 0,1 \\
$\mathbf{2 1}$ & 3,4 & 3,4 & 0,8 & 2,2 & 2,3 & 4,8 \\
$\mathbf{2 2}$ & 6,3 & 5,2 & 1,4 & 0,0 & 4,1 & 1,0 \\
$\mathbf{2 3}$ & 3,6 & 2,9 & 1,2 & 1,7 & 3,2 & 1,7 \\
$\mathbf{2 4}$ & 0,0 & 0,2 & 1,3 & 1,5 & 2,7 & 1,2 \\
$\mathbf{2 5}$ & 5,0 & 5,5 & 1,7 & 1,7 & 2,6 & 3,0 \\
$\mathbf{2 6}$ & 6,5 & 4,5 & 0,0 & 0,0 & 0,0 & 2,4 \\
$\mathbf{2 7}$ & 4,5 & 8,5 & 1,3 & 1,3 & 2,4 & 0,0 \\
$\mathbf{2 8}$ & 0,0 & 0,0 & 0,5 & 2,4 & 0,6 & 3,4 \\
$\mathbf{2 9}$ & 0,0 & 4,3 & 0,0 & 1,8 & 4,1 & 3,7 \\
\hline
\end{tabular}


TABELA A1(cont.) - Mensurações cefalométricas individuais, iniciais e finais, para o grupo 1, tratados com extrações de três pré-molares.

\begin{tabular}{ccccccc}
\hline \multicolumn{6}{c}{ JOVENS TRATADOS COM EXTRAÇÕES DE TRÊS PRÉ-MOLARES } \\
\hline \multicolumn{2}{c}{$\mathbf{N}$} & \multicolumn{2}{c}{ Ass. Go } & \multicolumn{2}{c}{ Ass. Ar } & \multicolumn{2}{c}{ Ass. Ra } \\
\cline { 2 - 6 } & INICIAL & FINAL & INICIAL & FINAL & INICIAL & FINAL \\
\hline $\mathbf{1}$ & 3,5 & 0,4 & 0,0 & 0,0 & 1,4 & 0,0 \\
$\mathbf{2}$ & 4,0 & 4,4 & 3,5 & 2,5 & 3,2 & 3,9 \\
$\mathbf{3}$ & 1,6 & 0,8 & 1,1 & 1,0 & 0,7 & 0,7 \\
$\mathbf{4}$ & 0,0 & 2,1 & 1,7 & 0,0 & 0,5 & 0,0 \\
$\mathbf{5}$ & 0,5 & 0,5 & 2,0 & 2,7 & 0,0 & 1,6 \\
$\mathbf{6}$ & 2,6 & 1,9 & 2,2 & 1,2 & 1,7 & 0,6 \\
$\mathbf{7}$ & 1,8 & 3,4 & 1,0 & 0,0 & 1,4 & 2,1 \\
$\mathbf{8}$ & $-0,7$ & 1,3 & 0,0 & 0,6 & 0,8 & 1,8 \\
$\mathbf{9}$ & 0,0 & 0,0 & 0,4 & 0,0 & 1,7 & 2,3 \\
$\mathbf{1 0}$ & 6,0 & 5,6 & 2,8 & 2,6 & 3,8 & 3,2 \\
$\mathbf{1 1}$ & 0,0 & 0,0 & 0,0 & 0,0 & 0,0 & 0,0 \\
$\mathbf{1 2}$ & 3,8 & 3,6 & 1,3 & 2,9 & 1,6 & 3,8 \\
$\mathbf{1 3}$ & 2,9 & 0,0 & 1,4 & 1,3 & 1,6 & 1,9 \\
$\mathbf{1 4}$ & 1,6 & 2,1 & 1,6 & 1,0 & 0,7 & 0,7 \\
$\mathbf{1 5}$ & 0,2 & 1,2 & 0,0 & 1,2 & 0,5 & 2,0 \\
$\mathbf{1 6}$ & 2,8 & 3,7 & 0,0 & 0,1 & 0,0 & 0,0 \\
$\mathbf{1 7}$ & 0,0 & 2,3 & 0,0 & 1,1 & 0,0 & 0,0 \\
$\mathbf{1 8}$ & 1,7 & 0,6 & $-0,2$ & 3,1 & 2,4 & 2,0 \\
$\mathbf{1 9}$ & 4,4 & 6,5 & 1,0 & 2,3 & 3,0 & 1,7 \\
$\mathbf{2 0}$ & 0,0 & 0,0 & 1,1 & 0,5 & 0,1 & 0,1 \\
$\mathbf{2 1}$ & 0,0 & 1,2 & 1,4 & 0,1 & 1,6 & 1,2 \\
$\mathbf{2 2}$ & 4,6 & 4,3 & 1,8 & 0,0 & 2,3 & 0,0 \\
$\mathbf{2 3}$ & 1,7 & 1,2 & 1,1 & 0,0 & 1,1 & 0,0 \\
$\mathbf{2 4}$ & 3,7 & 2,3 & 1,3 & 1,3 & 2,5 & 1,2 \\
$\mathbf{2 5}$ & $-0,1$ & 4,0 & 0,6 & 2,9 & 0,8 & 2,8 \\
$\mathbf{2 6}$ & 0,0 & 4,4 & 1,5 & 1,9 & 1,8 & 0,4 \\
$\mathbf{2 7}$ & $-1,3$ & 0,0 & 0,0 & 1,1 & 0,0 & 0,8 \\
$\mathbf{2 8}$ & $-0,9$ & 1,2 & 0,0 & 2,1 & 1,6 & 3,4 \\
$\mathbf{2 9}$ & 3,3 & 0,3 & 2,9 & 0,0 & 2,3 & 0,0 \\
\hline
\end{tabular}


TABELA A2 - Mensurações cefalométricas individuais, iniciais e finais, para o grupo 2, tratados com extrações de quatro pré-molares.

\begin{tabular}{ccccccc}
\hline \multicolumn{6}{c}{ JOVENS TRATADOS COM EXTRAÇÕES DE QUATRO PRÉ-MOLARES } \\
\hline \multirow{2}{*}{$\mathbf{N}$} & \multicolumn{2}{c}{ SNA } & \multicolumn{3}{c}{ CO-A } & \multicolumn{3}{c}{ SNB } \\
\cline { 2 - 7 } & INICIAL & FINAL & INICIAL & FINAL & INICIAL & FINAL \\
\hline $\mathbf{1}$ & 81,2 & 80,7 & 76,7 & 74,3 & 80,2 & 80,5 \\
$\mathbf{2}$ & 87,4 & 89,7 & 81,0 & 83,9 & 81,4 & 84,9 \\
$\mathbf{3}$ & 78,2 & 76,5 & 89,1 & 85,2 & 75,9 & 76,3 \\
$\mathbf{4}$ & 86,7 & 85,0 & 87,0 & 86,5 & 78,5 & 78,6 \\
$\mathbf{5}$ & 77,4 & 75,4 & 84,9 & 84,6 & 74,4 & 75,4 \\
$\mathbf{6}$ & 79,4 & 78,9 & 82,8 & 84,2 & 73,0 & 74,3 \\
$\mathbf{7}$ & 88,9 & 89,7 & 81,1 & 85,6 & 83,1 & 84,5 \\
$\mathbf{8}$ & 83,5 & 84,5 & 89,4 & 85,9 & 75,1 & 75,2 \\
$\mathbf{9}$ & 81,9 & 80,7 & 89,5 & 90,2 & 76,3 & 76,8 \\
$\mathbf{1 0}$ & 84,6 & 84,2 & 89,0 & 88,7 & 76,8 & 78,9 \\
$\mathbf{1 1}$ & 81,8 & 81,6 & 80,8 & 81,8 & 78,8 & 78,2 \\
$\mathbf{1 2}$ & 84,3 & 84,3 & 74,5 & 79,4 & 80,8 & 81,6 \\
$\mathbf{1 3}$ & 85,6 & 86,8 & 79,8 & 82,1 & 77,1 & 79,2 \\
$\mathbf{1 4}$ & 82,2 & 83,0 & 84,9 & 82,4 & 74,4 & 76,3 \\
$\mathbf{1 5}$ & 77,6 & 74,9 & 86,1 & 88,4 & 74,5 & 75,3 \\
$\mathbf{1 6}$ & 82,7 & 80,6 & 87,0 & 87,2 & 75,9 & 77,0 \\
$\mathbf{1 7}$ & 84,4 & 83,7 & 94,2 & 91,5 & 77,6 & 79,0 \\
$\mathbf{1 8}$ & 82,2 & 84,1 & 76,4 & 78,8 & 76,6 & 78,3 \\
$\mathbf{1 9}$ & 83,7 & 81,2 & 78,4 & 80,0 & 79,2 & 80,3 \\
$\mathbf{2 0}$ & 76,4 & 74,1 & 77,1 & 76,1 & 74,2 & 73,0 \\
$\mathbf{2 1}$ & 78,9 & 78,2 & 85,9 & 87,2 & 76,9 & 76,6 \\
$\mathbf{2 2}$ & 84,0 & 82,8 & 87,8 & 83,3 & 80,0 & 79,9 \\
$\mathbf{2 3}$ & 83,2 & 82,8 & 87,5 & 89,9 & 80,4 & 82,2 \\
$\mathbf{2 4}$ & 86,9 & 83,0 & 78,3 & 75,2 & 81,4 & 79,3 \\
$\mathbf{2 5}$ & 81,4 & 78,2 & 87,0 & 85,8 & 75,7 & 75,1 \\
$\mathbf{2 6}$ & 84,2 & 85,3 & 91,4 & 84,9 & 78,3 & 82,9 \\
$\mathbf{2 7}$ & 79,5 & 76,9 & 79,0 & 81,4 & 75,6 & 75,6 \\
$\mathbf{2 8}$ & 85,8 & 84,8 & 86,5 & 84,8 & 80,6 & 81,3 \\
$\mathbf{2 9}$ & 78,3 & 78,2 & 83,3 & 83,0 & 76,2 & 76,8 \\
\hline
\end{tabular}


TABELA A2(cont.) - Mensurações cefalométricas individuais, iniciais e finais, para o grupo 2, tratados com extrações de quatro pré-molares.

\begin{tabular}{|c|c|c|c|c|c|c|}
\hline \multicolumn{7}{|c|}{ JOVENS TRATADOS COM EXTRAÇÕES DE QUATRO PRÉ-MOLARES } \\
\hline \multirow[t]{2}{*}{$\mathbf{N}$} & \multicolumn{2}{|c|}{ CO-GN } & \multicolumn{2}{|c|}{ ANB } & \multicolumn{2}{|c|}{ Diff. MX-MD } \\
\hline & INICIAL & FINAL & INICIAL & FINAL & INICIAL & FINAL \\
\hline 1 & 105,5 & 101,4 & 0,9 & 0,3 & 28,8 & 27,1 \\
\hline 2 & 103,4 & 110,3 & 6,0 & 4,7 & 22,4 & 26,5 \\
\hline 3 & 108,5 & 106,5 & 2,3 & 0,1 & 19,4 & 21,2 \\
\hline 4 & 102,0 & 107,4 & 8,2 & 6,4 & 15,0 & 20,9 \\
\hline 5 & 110,7 & 116,3 & 2,9 & 0,0 & 25,8 & 31,7 \\
\hline 6 & 104,5 & 110,5 & 6,4 & 4,6 & 21,7 & 26,3 \\
\hline 7 & 102,7 & 107,6 & 5,8 & 5,2 & 21,6 & 21,9 \\
\hline 8 & 106,7 & 103,6 & 8,4 & 9,3 & 17,4 & 17,7 \\
\hline 9 & 111,2 & 115,9 & 5,7 & 3,9 & 21,7 & 25,7 \\
\hline 10 & 115,0 & 119,1 & 7,8 & 5,3 & 26,0 & 30,4 \\
\hline 11 & 109,3 & 110,0 & 2,9 & 3,4 & 28,5 & 28,3 \\
\hline 12 & 96,5 & 102,8 & 3,4 & 2,7 & 22,1 & 23,4 \\
\hline 13 & 102,1 & 106,0 & 8,4 & 7,6 & 22,3 & 23,9 \\
\hline 14 & 105,5 & 106,6 & 7,8 & 6,6 & 20,6 & 24,3 \\
\hline 15 & 119,3 & 128,8 & 3,1 & $-0,4$ & 33,2 & 40,4 \\
\hline 16 & 111,1 & 119,0 & 6,7 & 3,6 & 24,1 & 31,9 \\
\hline 17 & 120,9 & 123,1 & 6,8 & 4,7 & 26,7 & 31,6 \\
\hline 18 & 99,0 & 103,5 & 5,6 & 5,8 & 22,6 & 24,7 \\
\hline 19 & 98,9 & 107,3 & 4,5 & 0,9 & 20,5 & 27,4 \\
\hline 20 & 101,9 & 103,4 & 2,2 & 1,1 & 24,8 & 27,3 \\
\hline 21 & 117,8 & 125,3 & 2,0 & 1,6 & 31,9 & 38,1 \\
\hline 22 & 109,7 & 111,1 & 4,0 & 2,9 & 21,9 & 27,8 \\
\hline 23 & 110,5 & 120,4 & 2,8 & 0,6 & 23,0 & 30,4 \\
\hline 24 & 101,5 & 100,5 & 5,5 & 3,6 & 23,2 & 25,3 \\
\hline 25 & 109,3 & 111,5 & 5,8 & 3,1 & 22,3 & 25,6 \\
\hline 26 & 116,0 & 115,8 & 5,9 & 2,5 & 24,6 & 30,9 \\
\hline 27 & 106,1 & 116,4 & 3,9 & 1,4 & 27,1 & 34,9 \\
\hline 28 & 108,0 & 111,9 & 5,2 & 3,5 & 21,4 & 27,1 \\
\hline 29 & 113,6 & 116,6 & 2,1 & 1,4 & 30,3 & 33,6 \\
\hline
\end{tabular}


TABELA A2(cont.) - Mensurações cefalométricas individuais, iniciais e finais, para o grupo 2, tratados com extrações de quatro pré-molares.

\begin{tabular}{ccccccc}
\hline \multicolumn{6}{c}{ JOVENS TRATADOS COM EXTRAÇÕES DE QUATRO PRÉ-MOLARES } \\
\hline $\mathbf{N}$ & \multicolumn{2}{c}{ SN.GoGN } & \multicolumn{3}{c}{ FMA } & \multicolumn{3}{c}{ AFAI } \\
\cline { 2 - 7 } & INICIAL & FINAL & INICIAL & FINAL & INICIAL & FINAL \\
\hline $\mathbf{1}$ & 35,6 & 35,5 & 27,1 & 28,7 & 64,9 & 63,1 \\
$\mathbf{2}$ & 32,7 & 28,6 & 25,9 & 23,3 & 61,9 & 65,9 \\
$\mathbf{3}$ & 27,9 & 26,3 & 16,6 & 22,1 & 57,3 & 57,6 \\
$\mathbf{4}$ & 26,1 & 26,0 & 20,8 & 23,0 & 58,1 & 63,5 \\
$\mathbf{5}$ & 36,3 & 34,3 & 25,9 & 22,6 & 63,0 & 66,0 \\
$\mathbf{6}$ & 42,0 & 41,1 & 31,5 & 30,4 & 65,2 & 67,3 \\
$\mathbf{7}$ & 29,3 & 25,4 & 31,1 & 22,3 & 61,8 & 58,6 \\
$\mathbf{8}$ & 37,6 & 37,1 & 29,3 & 28,8 & 64,2 & 64,6 \\
$\mathbf{9}$ & 35,5 & 32,9 & 25,8 & 23,4 & 70,3 & 68,0 \\
$\mathbf{1 0}$ & 38,0 & 36,2 & 26,2 & 24,9 & 71,3 & 74,4 \\
$\mathbf{1 1}$ & 35,2 & 38,1 & 31,7 & 29,9 & 74,0 & 74,4 \\
$\mathbf{1 2}$ & 26,3 & 25,3 & 23,1 & 20,3 & 55,2 & 56,3 \\
$\mathbf{1 3}$ & 37,1 & 33,2 & 32,7 & 35,2 & 68,1 & 68,3 \\
$\mathbf{1 4}$ & 42,5 & 44,9 & 38,8 & 39,3 & 63,1 & 65,1 \\
$\mathbf{1 5}$ & 40,8 & 40,5 & 34,3 & 30,6 & 77,2 & 79,2 \\
$\mathbf{1 6}$ & 31,7 & 29,3 & 22,8 & 24,5 & 66,5 & 75,2 \\
$\mathbf{1 7}$ & 35,0 & 30,9 & 26,0 & 32,3 & 73,6 & 74,8 \\
$\mathbf{1 8}$ & 34,6 & 33,4 & 26,7 & 28,5 & 64,3 & 67,7 \\
$\mathbf{1 9}$ & 32,7 & 32,3 & 23,9 & 20,5 & 59,8 & 61,2 \\
$\mathbf{2 0}$ & 32,9 & 33,1 & 25,9 & 24,6 & 60,3 & 63,9 \\
$\mathbf{2 1}$ & 38,1 & 39,7 & 33,3 & 28,9 & 73,2 & 75,7 \\
$\mathbf{2 2}$ & 27,5 & 30,0 & 28,7 & 26,3 & 62,7 & 66,1 \\
$\mathbf{2 3}$ & 25,0 & 21,7 & 17,8 & 16,5 & 57,7 & 58,6 \\
$\mathbf{2 4}$ & 25,1 & 27,7 & 20,5 & 21,0 & 57,1 & 59,6 \\
$\mathbf{2 5}$ & 34,0 & 35,4 & 25,0 & 24,2 & 65,4 & 66,5 \\
$\mathbf{2 6}$ & 39,4 & 37,3 & 30,2 & 29,7 & 70,0 & 71,2 \\
$\mathbf{2 7}$ & 38,4 & 39,2 & 28,2 & 28,2 & 65,7 & 71,7 \\
$\mathbf{2 8}$ & 32,2 & 31,4 & 31,5 & 31,2 & 65,9 & 70,4 \\
$\mathbf{2 9}$ & 39,1 & 39,7 & 25,8 & 30,3 & 66,4 & 72,3 \\
\hline
\end{tabular}


TABELA A2(cont.) - Mensurações cefalométricas individuais, iniciais e finais, para o grupo 2, tratados com extrações de quatro pré-molares.

\begin{tabular}{|c|c|c|c|c|c|c|}
\hline \multicolumn{7}{|c|}{ JOVENS TRATADOS COM EXTRAÇÕES DE QUATRO PRÉ-MOLARES } \\
\hline \multirow[t]{2}{*}{$\mathbf{N}$} & \multicolumn{2}{|c|}{ U6-PTV } & \multicolumn{2}{|c|}{ U6-PP } & \multicolumn{2}{|c|}{ L6-PTV } \\
\hline & INICIAL & FINAL & INICIAL & FINAL & INICIAL & FINAL \\
\hline 1 & 19,4 & 18,8 & 23,5 & 22,8 & 19,7 & 19,2 \\
\hline 2 & 15,6 & 22,1 & 23,8 & 24,6 & 13,7 & 22,3 \\
\hline 3 & 19,4 & 13,5 & 19,5 & 21,9 & 15,2 & 12,0 \\
\hline 4 & 19,5 & 18,8 & 21,5 & 23,7 & 17,5 & 17,9 \\
\hline 5 & 15,4 & 16,3 & 20,8 & 22,9 & 14,4 & 18,8 \\
\hline 6 & 18,6 & 20,7 & 23,0 & 24,3 & 16,6 & 21,4 \\
\hline 7 & 12,8 & 18,4 & 21,6 & 21,8 & 11,8 & 19,9 \\
\hline 8 & 18,2 & 24,6 & 23,6 & 23,2 & 17,9 & 23,7 \\
\hline 9 & 17,3 & 20,4 & 24,1 & 25,5 & 18,3 & 22,1 \\
\hline 10 & 22,7 & 26,5 & 27,4 & 29,1 & 21,8 & 26,9 \\
\hline 11 & 14,9 & 17,9 & 27,1 & 27,3 & 13,2 & 19,7 \\
\hline 12 & 13,7 & 17,7 & 17,6 & 17,8 & 12,9 & 19,1 \\
\hline 13 & 13,5 & 11,4 & 22,6 & 22,8 & 10,1 & 11,1 \\
\hline 14 & 13,0 & 17,5 & 21,0 & 23,9 & 12,8 & 18,7 \\
\hline 15 & 16,2 & 20,0 & 29,6 & 30,3 & 14,4 & 20,1 \\
\hline 16 & 14,5 & 19,0 & 21,0 & 26,2 & 14,4 & 19,9 \\
\hline 17 & 18,8 & 17,0 & 26,0 & 28,3 & 18,1 & 17,1 \\
\hline 18 & 15,7 & 18,9 & 23,6 & 23,7 & 13,4 & 19,2 \\
\hline 19 & 16,0 & 22,6 & 21,5 & 23,2 & 15,2 & 23,7 \\
\hline 20 & 13,8 & 14,8 & 23,3 & 24,5 & 12,7 & 14,8 \\
\hline 21 & 9,5 & 19,3 & 25,7 & 29,0 & 11,4 & 22,1 \\
\hline 22 & 10,9 & 16,6 & 20,0 & 23,0 & 10,3 & 17,2 \\
\hline 23 & 13,4 & 16,5 & 20,3 & 21,8 & 11,9 & 17,3 \\
\hline 24 & 15,6 & 17,4 & 19,3 & 21,1 & 14,4 & 17,7 \\
\hline 25 & 19,8 & 19,6 & 21,4 & 23,1 & 17,3 & 21,4 \\
\hline 26 & 17,1 & 18,6 & 24,9 & 28,3 & 16,4 & 19,6 \\
\hline 27 & 12,7 & 17,7 & 23,5 & 26,0 & 13,3 & 18,8 \\
\hline 28 & 16,3 & 19,3 & 23,8 & 26,0 & 15,1 & 20,4 \\
\hline 29 & 16,9 & 16,8 & 24,3 & 27,1 & 17,1 & 17,5 \\
\hline
\end{tabular}


TABELA A2(cont.) - Mensurações cefalométricas individuais, iniciais e finais, para o grupo 2, tratados com extrações de quatro pré-molares.

\begin{tabular}{|c|c|c|c|c|c|c|}
\hline \multicolumn{7}{|c|}{ JOVENS TRATADOS COM EXTRAÇÕES DE QUATRO PRÉ-MOLARES } \\
\hline \multirow[t]{2}{*}{$\mathbf{N}$} & \multicolumn{2}{|c|}{ L6-PM } & \multicolumn{2}{|c|}{ 1.NA } & \multicolumn{2}{|c|}{ 1-NA } \\
\hline & INICIAL & FINAL & INICIAL & FINAL & INICIAL & FINAL \\
\hline 1 & 28,0 & 29,4 & 26,6 & 29,2 & 6,9 & 7,1 \\
\hline 2 & 27,2 & 30,8 & 23,7 & 21,8 & 5,9 & 2,9 \\
\hline 3 & 27,9 & 28,3 & 33,5 & 31,7 & 5,5 & 3,8 \\
\hline 4 & 26,9 & 30,9 & 18,4 & 21,1 & 3,2 & $-0,1$ \\
\hline 5 & 30,2 & 32,0 & 23,4 & 28,2 & 3,5 & 4,9 \\
\hline 6 & 29,0 & 31,0 & 21,8 & 12,0 & 2,1 & 0,1 \\
\hline 7 & 29,0 & 29,2 & 21,9 & 24,7 & 0,2 & $-2,0$ \\
\hline 8 & 30,1 & 31,9 & 27,4 & 17,3 & 7,5 & 2,2 \\
\hline 9 & 29,6 & 31,5 & 27,2 & 26,4 & 5,2 & 1,6 \\
\hline 10 & 35,6 & 38,8 & 22,2 & 19,8 & 2,4 & 1,5 \\
\hline 11 & 29,4 & 32,7 & 41,0 & 19,7 & 12,4 & 4,2 \\
\hline 12 & 29,0 & 32,5 & 29,9 & 23,3 & 3,2 & 1,7 \\
\hline 13 & 31,8 & 33,9 & 26,1 & 13,5 & 4,8 & $-1,7$ \\
\hline 14 & 27,9 & 29,3 & 16,9 & 12,6 & 4,1 & 0,3 \\
\hline 15 & 29,3 & 34,8 & 29,7 & 27,0 & 7,1 & 7,8 \\
\hline 16 & 31,0 & 36,6 & 34,7 & 29,8 & 10,1 & 7,7 \\
\hline 17 & 32,1 & 35,7 & 31,3 & 23,1 & 6,0 & 1,3 \\
\hline 18 & 27,4 & 31,5 & 23,7 & 11,5 & 4,3 & $-0,7$ \\
\hline 19 & 26,3 & 28,8 & 19,5 & 28,3 & 2,0 & 4,5 \\
\hline 20 & 27,9 & 29,8 & 22,6 & 21,9 & 4,4 & 3,5 \\
\hline 21 & 31,9 & 33,8 & 18,7 & 18,3 & 3,5 & 3,3 \\
\hline 22 & 30,2 & 33,1 & 20,5 & 25,3 & 3,5 & 4,2 \\
\hline 23 & 26,9 & 30,3 & 16,0 & 23,6 & 0,8 & 3,3 \\
\hline 24 & 29,5 & 31,5 & 19,7 & 18,0 & 2,7 & 0,8 \\
\hline 25 & 31,1 & 31,4 & 24,1 & 9,2 & 3,4 & $-1,5$ \\
\hline 26 & 30,1 & 30,0 & 31,2 & 10,8 & 7,0 & 3,2 \\
\hline 27 & 27,1 & 29,3 & 24,6 & 18,5 & 3,9 & 2,8 \\
\hline 28 & 28,3 & 33,1 & 26,6 & 20,9 & 7,2 & 3,8 \\
\hline 29 & 27,3 & 32,6 & 36,3 & 21,7 & 12,5 & 7,0 \\
\hline
\end{tabular}


TABELA A2(cont.) - Mensurações cefalométricas individuais, iniciais e finais, para o grupo 2, tratados com extrações de quatro pré-molares.

\begin{tabular}{|c|c|c|c|c|c|c|}
\hline \multicolumn{7}{|c|}{ JOVENS TRATADOS COM EXTRAÇÕES DE QUATRO PRÉ-MOLARES } \\
\hline \multirow[t]{2}{*}{$\mathbf{N}$} & \multicolumn{2}{|c|}{ 1.PP } & \multicolumn{2}{|c|}{ 1-Aperp } & \multicolumn{2}{|c|}{ 1-PP } \\
\hline & INICIAL & FINAL & INICIAL & FINAL & INICIAL & FINAL \\
\hline 1 & 116,8 & 116,7 & 8,2 & 6,7 & 28,6 & 27,7 \\
\hline 2 & 119,6 & 112,2 & 7,6 & 4,6 & 28,4 & 29,8 \\
\hline 3 & 118,6 & 116,7 & 5,3 & 1,1 & 24,5 & 24,0 \\
\hline 4 & 110,4 & 112,6 & 4,3 & $-0,1$ & 25,7 & 26,5 \\
\hline 5 & 110,5 & 113,7 & 2,7 & 4,1 & 26,5 & 26,0 \\
\hline 6 & 113,2 & 101,2 & 3,0 & 0,7 & 27,2 & 26,0 \\
\hline 7 & 115,4 & 121,3 & 0,2 & $-0,8$ & 24,6 & 24,6 \\
\hline 8 & 122,3 & 113,7 & 8,9 & 4,2 & 27,2 & 25,7 \\
\hline 9 & 116,5 & 116,2 & 6,7 & 2,9 & 29,5 & 29,0 \\
\hline 10 & 124,2 & 120,1 & 6,1 & 4,6 & 27,8 & 29,0 \\
\hline 11 & 123,3 & 102,5 & 11,4 & 4,2 & 32,6 & 32,7 \\
\hline 12 & 121,3 & 115,0 & 3,3 & 2,2 & 21,4 & 21,7 \\
\hline 13 & 118,4 & 106,6 & 5,9 & $-2,4$ & 26,8 & 28,1 \\
\hline 14 & 110,6 & 107,6 & 3,3 & 0,1 & 28,2 & 27,6 \\
\hline 15 & 114,2 & 108,4 & 5,3 & 6,0 & 33,7 & 35,1 \\
\hline 16 & 123,5 & 112,0 & 10,8 & 5,9 & 28,4 & 33,3 \\
\hline 17 & 121,7 & 114,3 & 7,4 & $-0,9$ & 30,0 & 30,6 \\
\hline 18 & 111,7 & 99,3 & 5,0 & $-0,1$ & 28,2 & 28,9 \\
\hline 19 & 108,9 & 116,0 & 3,2 & 5,9 & 25,8 & 24,8 \\
\hline 20 & 108,5 & 106,0 & 2,8 & 1,9 & 26,9 & 28,1 \\
\hline 21 & 106,9 & 108,4 & 0,9 & 3,4 & 32,1 & 32,7 \\
\hline 22 & 108,4 & 113,5 & 2,1 & 3,2 & 27,4 & 27,0 \\
\hline 23 & 106,8 & 115,3 & 1,1 & 2,6 & 25,2 & 24,1 \\
\hline 24 & 113,3 & 109,8 & 3,6 & 0,9 & 23,3 & 24,7 \\
\hline 25 & 112,7 & 96,0 & 4,1 & $-1,7$ & 27,3 & 27,7 \\
\hline 26 & 125,7 & 102,2 & 9,4 & 4,8 & 28,4 & 31,6 \\
\hline 27 & 111,7 & 101,3 & 4,8 & 2,9 & 28,1 & 30,9 \\
\hline 28 & 113,3 & 109,4 & 6,7 & 3,1 & 30,2 & 29,7 \\
\hline 29 & 122,4 & 108,0 & 13,0 & 6,1 & 27,5 & 31,8 \\
\hline
\end{tabular}


TABELA A2(cont.) - Mensurações cefalométricas individuais, iniciais e finais, para o grupo 2, tratados com extrações de quatro pré-molares.

\begin{tabular}{|c|c|c|c|c|c|c|}
\hline \multicolumn{7}{|c|}{ JOVENS TRATADOS COM EXTRAÇÕES DE QUATRO PRÉ-MOLARES } \\
\hline \multirow[t]{2}{*}{$\mathbf{N}$} & \multicolumn{2}{|c|}{$1 . \mathrm{NB}$} & \multicolumn{2}{|c|}{$1-\mathrm{NB}$} & \multicolumn{2}{|c|}{ 1.PM } \\
\hline & INICIAL & FINAL & INICIAL & FINAL & INICIAL & FINAL \\
\hline 1 & 35,3 & 26,4 & 5,2 & 3,7 & 96,6 & 87,8 \\
\hline 2 & 37,6 & 25,5 & 8,2 & 3,9 & 102,1 & 90,6 \\
\hline 3 & 24,4 & 21,5 & 3,2 & 0,7 & 98,8 & 97,0 \\
\hline 4 & 41,9 & 26,1 & 8,8 & 5,1 & 114,0 & 98,4 \\
\hline 5 & 24,3 & 24,5 & 4,1 & 2,7 & 91,4 & 91,9 \\
\hline 6 & 29,6 & 23,6 & 6,4 & 4,6 & 92,1 & 86,0 \\
\hline 7 & 32,5 & 31,9 & 5,6 & 2,1 & 98,1 & 100,3 \\
\hline 8 & 36,2 & 30,4 & 9,7 & 9,1 & 100,9 & 95,2 \\
\hline 9 & 33,1 & 22,7 & 7,2 & 3,2 & 98,1 & 90,1 \\
\hline 10 & 41,6 & 31,7 & 11,1 & 6,3 & 104,3 & 94,2 \\
\hline 11 & 24,5 & 26,6 & 4,0 & 5,1 & 86,6 & 87,7 \\
\hline 12 & 32,7 & 19,2 & 4,9 & 2,1 & 102,8 & 89,9 \\
\hline 13 & 28,6 & 38,0 & 6,6 & 6,8 & 91,8 & 102,4 \\
\hline 14 & 35,9 & 35,9 & 8,6 & 7,5 & 96,1 & 91,9 \\
\hline 15 & 23,3 & 26,5 & 4,9 & 4,1 & 85,3 & 89,0 \\
\hline 16 & 36,0 & 32,7 & 11,4 & 7,9 & 107,1 & 104,6 \\
\hline 17 & 32,7 & 32,0 & 7,3 & 5,0 & 98,5 & 100,4 \\
\hline 18 & 30,8 & 22,4 & 6,0 & 3,6 & 97,1 & 88,7 \\
\hline 19 & 21,3 & 23,1 & 3,3 & 2,5 & 87,0 & 88,2 \\
\hline 20 & 23,2 & 19,6 & 3,4 & 2,4 & 94,4 & 91,4 \\
\hline 21 & 20,1 & 19,3 & 3,7 & 2,7 & 83,1 & 80,6 \\
\hline 22 & 29,4 & 24,2 & 5,3 & 4,2 & 98,1 & 91,7 \\
\hline 23 & 22,2 & 18,3 & 2,3 & 0,7 & 93,8 & 92,4 \\
\hline 24 & 29,7 & 28,4 & 5,2 & 3,6 & 100,8 & 98,9 \\
\hline 25 & 27,2 & 15,8 & 5,5 & 0,7 & 94,8 & 83,3 \\
\hline 26 & 34,0 & 24,0 & 8,8 & 3,6 & 93,3 & 81,7 \\
\hline 27 & 28,2 & 19,1 & 5,1 & 2,6 & 90,9 & 81,4 \\
\hline 28 & 35,8 & 26,5 & 8,7 & 6,7 & 101,2 & 90,8 \\
\hline 29 & 21,2 & 30,4 & 5,1 & 5,7 & 85,0 & 92,2 \\
\hline
\end{tabular}


TABELA A2(cont.) - Mensurações cefalométricas individuais, iniciais e finais, para o grupo 2, tratados com extrações de quatro pré-molares.

\begin{tabular}{|c|c|c|c|c|c|c|}
\hline \multicolumn{7}{|c|}{ JOVENS TRATADOS COM EXTRAÇÕES DE QUATRO PRÉ-MOLARES } \\
\hline \multirow[t]{2}{*}{$\mathbf{N}$} & \multicolumn{2}{|c|}{ 1-Bperp } & \multicolumn{2}{|c|}{ 1-PM } & \multicolumn{2}{|c|}{ H.NB } \\
\hline & INICIAL & FINAL & INICIAL & FINAL & INICIAL & FINAL \\
\hline 1 & 4,6 & 4,1 & 35,9 & 36,2 & 14,1 & 11,8 \\
\hline 2 & 8,9 & 4,2 & 39,2 & 39,1 & 13,9 & 9,5 \\
\hline 3 & 4,1 & 2,5 & 36,7 & 33,6 & 8,7 & $-0,2$ \\
\hline 4 & 10,5 & 7,4 & 36,6 & 37,1 & 23,1 & 17,7 \\
\hline 5 & 5,6 & 3,3 & 39,0 & 39,8 & 12,2 & 7,2 \\
\hline 6 & 7,7 & 5,6 & 37,3 & 39,1 & 14,9 & 14,0 \\
\hline 7 & 7,2 & 2,4 & 37,8 & 33,8 & 12,5 & 10,0 \\
\hline 8 & 11,6 & 10,4 & 43,3 & 40,8 & 20,4 & 20,4 \\
\hline 9 & 7,7 & 3,3 & 43,0 & 39,5 & 17,0 & 12,9 \\
\hline 10 & 10,5 & 5,4 & 45,5 & 47,3 & 23,5 & 21,4 \\
\hline 11 & 5,8 & 6,1 & 44,3 & 43,3 & 12,3 & 10,4 \\
\hline 12 & 5,8 & 2,3 & 34,7 & 35,3 & 8,8 & 2,4 \\
\hline 13 & 8,6 & 9,6 & 42,0 & 40,4 & 17,7 & 12,4 \\
\hline 14 & 11,5 & 9,7 & 39,4 & 37,4 & 17,1 & 9,5 \\
\hline 15 & 7,4 & 5,3 & 42,7 & 43,3 & 14,2 & 11,7 \\
\hline 16 & 13,4 & 11,0 & 43,3 & 45,4 & 20,7 & 13,4 \\
\hline 17 & 8,3 & 8,0 & 43,1 & 43,3 & 16,1 & 10,0 \\
\hline 18 & 7,2 & 5,1 & 37,3 & 38,3 & 19,8 & 17,1 \\
\hline 19 & 3,6 & 1,4 & 36,6 & 36,8 & 13,6 & 10,2 \\
\hline 20 & 5,4 & 4,2 & 36,8 & 36,4 & 9,2 & 7,1 \\
\hline 21 & 6,7 & 3,1 & 40,5 & 41,2 & 10,6 & 7,3 \\
\hline 22 & 7,9 & 6,0 & 38,6 & 40,2 & 16,1 & 12,8 \\
\hline 23 & 2,8 & 1,4 & 34,4 & 34,8 & 14,1 & 9,7 \\
\hline 24 & 6,1 & 4,4 & 36,6 & 34,7 & 13,5 & 6,7 \\
\hline 25 & 6,7 & 1,7 & 41,0 & 36,3 & 14,4 & 10,0 \\
\hline 26 & 8,7 & 3,3 & 43,9 & 41,0 & 13,9 & 11,9 \\
\hline 27 & 5,6 & 3,0 & 37,0 & 37,5 & 13,4 & 8,1 \\
\hline 28 & 10,9 & 8,7 & 39,9 & 41,1 & 19,9 & 17,6 \\
\hline 29 & 5,4 & 6,7 & 37,4 & 40,0 & 14,1 & 12,6 \\
\hline
\end{tabular}


TABELA A2(cont.) - Mensurações cefalométricas individuais, iniciais e finais, para o grupo 2, tratados com extrações de quatro pré-molares.

\begin{tabular}{|c|c|c|c|c|c|c|}
\hline \multicolumn{7}{|c|}{ JOVENS TRATADOS COM EXTRAÇÕES DE QUATRO PRÉ-MOLARES } \\
\hline \multirow[t]{2}{*}{$\mathbf{N}$} & \multicolumn{2}{|c|}{$\mathrm{H}-\mathrm{Nariz}$} & \multicolumn{2}{|c|}{ H-Li } & \multicolumn{2}{|c|}{ Ass. MX } \\
\hline & INICIAL & FINAL & INICIAL & FINAL & INICIAL & FINAL \\
\hline 1 & $-0,1$ & 2,5 & $-1,2$ & $-1,1$ & 1,9 & 1,7 \\
\hline 2 & $-1,8$ & 2,0 & 0,5 & 3,7 & 3,1 & 3,4 \\
\hline 3 & 9,1 & 16,8 & 1,3 & 0,0 & 2,2 & 2,6 \\
\hline 4 & $-3,7$ & 3,8 & 1,7 & 0,4 & 0,7 & 0,0 \\
\hline 5 & 4,9 & 8,2 & 1,1 & $-0,2$ & 3,3 & 1,6 \\
\hline 6 & 1,3 & 4,4 & 3,9 & 3,4 & $-0,2$ & 2,9 \\
\hline 7 & 1,7 & 3,9 & 2,6 & 0,8 & 0,1 & 2,0 \\
\hline 8 & $-1,5$ & 0,9 & 2,8 & 3,7 & 2,2 & 3,9 \\
\hline 9 & $-2,2$ & 3,1 & 1,8 & $-0,4$ & 5,0 & 2,9 \\
\hline 10 & $-3,1$ & $-0,8$ & 5,2 & 5,9 & $-0,1$ & 2,7 \\
\hline 11 & $-1,0$ & 0,7 & 0,8 & 2,2 & 2,3 & 2,0 \\
\hline 12 & 5,4 & 9,3 & 1,4 & 0,1 & 0,0 & 0,0 \\
\hline 13 & $-1,9$ & 2,6 & 2,8 & 1,6 & 0,0 & 1,4 \\
\hline 14 & $-0,3$ & 9,8 & 3,1 & $-0,9$ & 2,7 & 3,0 \\
\hline 15 & 5,0 & 8,7 & 5,4 & 3,6 & 3,1 & 2,4 \\
\hline 16 & $-7,1$ & 1,1 & 4,2 & 2,6 & 4,0 & 5,2 \\
\hline 17 & $-0,9$ & 8,8 & 1,9 & 1,4 & 2,5 & 2,8 \\
\hline 18 & $-3,9$ & $-0,3$ & 2,4 & 2,5 & 0,0 & 0,0 \\
\hline 19 & 1,9 & 5,5 & 1,9 & 1,6 & 0,0 & $-0,1$ \\
\hline 20 & 5,1 & 6,5 & 1,1 & 0,5 & 2,2 & 2,7 \\
\hline 21 & 2,6 & 8,1 & 1,2 & 1,3 & 4,1 & 3,2 \\
\hline 22 & 0,0 & 3,8 & 1,6 & 0,0 & 0,8 & 0,0 \\
\hline 23 & 3,7 & 9,6 & 0,1 & $-1,4$ & 3,7 & 3,7 \\
\hline 24 & 6,1 & 11,2 & 0,1 & 0,1 & $-0,1$ & 2,5 \\
\hline 25 & 1,1 & 5,0 & 3,0 & $-0,1$ & 3,4 & 2,3 \\
\hline 26 & 2,4 & 5,4 & 5,6 & 1,6 & 2,2 & 3,3 \\
\hline 27 & 3,5 & 12,0 & 2,0 & 0,7 & $-0,1$ & 0,0 \\
\hline 28 & $-5,7$ & $-0,8$ & 4,6 & 3,7 & 4,5 & 1,7 \\
\hline 29 & 0,8 & 3,2 & 1,3 & 1,3 & 5,3 & 3,4 \\
\hline
\end{tabular}


TABELA A2(cont.) - Mensurações cefalométricas individuais, iniciais e finais, para o grupo 2, tratados com extrações de quatro pré-molares.

\begin{tabular}{|c|c|c|c|c|c|c|}
\hline \multicolumn{7}{|c|}{ JOVENS TRATADOS COM EXTRAÇÕES DE QUATRO PRÉ-MOLARES } \\
\hline \multirow[t]{2}{*}{$\mathbf{N}$} & \multicolumn{2}{|c|}{ Ass. MD } & \multicolumn{2}{|c|}{ Ass. U6 } & \multicolumn{2}{|c|}{ Ass. L6 } \\
\hline & INICIAL & FINAL & INICIAL & FINAL & INICIAL & FINAL \\
\hline 1 & 3,0 & 1,0 & 2,0 & 1,3 & 1,3 & 0,9 \\
\hline 2 & 1,0 & 0,9 & 0,0 & $-0,3$ & 4,8 & $-0,2$ \\
\hline 3 & 1,0 & 2,2 & 2,2 & 0,0 & 1,3 & 0,0 \\
\hline 4 & 0,8 & 3,9 & 1,6 & 2,8 & 1,8 & 2,7 \\
\hline 5 & 0,6 & 0,8 & 0,0 & 0,0 & 2,0 & 0,1 \\
\hline 6 & 0,3 & 1,7 & 2,4 & 2,5 & 1,7 & 2,3 \\
\hline 7 & 2,8 & 0,8 & 2,2 & 2,2 & 2,0 & 2,7 \\
\hline 8 & 1,3 & 2,2 & 1,2 & 1,3 & 4,0 & 2,0 \\
\hline 9 & 3,9 & 2,2 & 1,8 & 0,9 & 4,0 & 1,1 \\
\hline 10 & 1,9 & 0,2 & 2,4 & 1,0 & 2,1 & 1,5 \\
\hline 11 & 1,6 & 1,6 & 2,1 & 0,8 & 1,9 & 0,9 \\
\hline 12 & 1,2 & 2,1 & 2,5 & 2,1 & 0,0 & 1,8 \\
\hline 13 & 0,6 & 2,3 & 3,0 & 0,0 & 0,0 & 0,0 \\
\hline 14 & 1,9 & 2,3 & 1,8 & 2,1 & 1,5 & 1,5 \\
\hline 15 & 0,2 & 1,0 & 1,7 & 1,2 & 1,6 & 1,0 \\
\hline 16 & 1,3 & 1,5 & 1,8 & 3,7 & 2,9 & 3,1 \\
\hline 17 & 2,3 & 4,4 & 2,1 & 0,0 & 1,5 & 0,0 \\
\hline 18 & 0,2 & 0,8 & 1,6 & 3,0 & 3,1 & 3,0 \\
\hline 19 & 2,1 & 0,2 & 0,0 & 2,6 & 2,3 & 2,4 \\
\hline 20 & 0,6 & 0,7 & 1,8 & $-0,1$ & 1,5 & 0,0 \\
\hline 21 & 1,9 & 2,5 & 1,2 & 2,3 & 2,2 & 3,2 \\
\hline 22 & 1,0 & 1,1 & 2,2 & 1,1 & 1,5 & 1,4 \\
\hline 23 & 0,2 & 0,6 & 2,4 & 0,0 & 2,0 & 0,0 \\
\hline 24 & 0,3 & 1,1 & 3,1 & 1,4 & 1,4 & 1,3 \\
\hline 25 & 3,3 & 0,0 & 1,4 & 3,1 & 2,2 & 3,0 \\
\hline 26 & $-0,5$ & 0,9 & 3,0 & 3,2 & 0,0 & 3,2 \\
\hline 27 & 0,7 & 0,5 & 1,2 & 1,8 & 2,3 & 2,4 \\
\hline 28 & 0,9 & 1,3 & 1,5 & 0,0 & 1,3 & 0,0 \\
\hline 29 & 2,2 & 3,2 & 2,5 & 2,0 & 4,2 & 2,1 \\
\hline
\end{tabular}


TABELA A2(cont.) - Mensurações cefalométricas individuais, iniciais e finais, para o grupo 2, tratados com extrações de quatro pré-molares.

\begin{tabular}{|c|c|c|c|c|c|c|}
\hline \multicolumn{7}{|c|}{ JOVENS TRATADOS COM EXTRAÇÕES DE QUATRO PRÉ-MOLARES } \\
\hline \multirow[t]{2}{*}{$\mathbf{N}$} & \multicolumn{2}{|c|}{ Ass. Or } & \multicolumn{2}{|c|}{ Ass. Ptm } & \multicolumn{2}{|c|}{ Ass. AGo } \\
\hline & INICIAL & FINAL & INICIAL & FINAL & INICIAL & FINAL \\
\hline 1 & 3,7 & 2,3 & 0,0 & 1,0 & 4,2 & 0,0 \\
\hline 2 & 3,4 & 3,8 & 2,7 & 2,9 & 0,0 & 0,0 \\
\hline 3 & 4,0 & 4,1 & 0,3 & 1,0 & 2,7 & 3,9 \\
\hline 4 & 3,0 & 0,0 & 1,6 & 0,0 & 3,9 & 4,0 \\
\hline 5 & 4,9 & 3,2 & 1,7 & 0,0 & 0,0 & 2,1 \\
\hline 6 & 0,2 & 4,4 & 0,1 & 1,4 & 1,1 & 1,5 \\
\hline 7 & 0,1 & 3,3 & 0,1 & 0,7 & 2,7 & 2,1 \\
\hline 8 & 3,6 & 7,0 & 0,7 & 0,7 & 2,7 & 0,0 \\
\hline 9 & 8,5 & 5,7 & 1,5 & 0,0 & 5,6 & 4,4 \\
\hline 10 & 0,1 & 4,1 & 0,0 & 1,3 & 2,0 & 1,1 \\
\hline 11 & 4,5 & 3,8 & 0,0 & 0,1 & 4,1 & 3,6 \\
\hline 12 & 0,0 & 0,1 & 0,0 & 0,1 & 1,0 & 4,2 \\
\hline 13 & 0,0 & 1,2 & 0,0 & 1,6 & 0,8 & 2,7 \\
\hline 14 & 2,4 & 4,2 & 3,0 & 1,8 & 3,2 & 1,7 \\
\hline 15 & 5,3 & 4,8 & 0,9 & 0,0 & 0,0 & 1,5 \\
\hline 16 & 6,3 & 7,9 & 1,7 & 2,5 & 0,1 & 0,0 \\
\hline 17 & 3,7 & 3,1 & 1,2 & 2,5 & 1,2 & 7,0 \\
\hline 18 & 0,0 & 0,0 & 0,0 & 0,0 & 0,6 & 0,0 \\
\hline 19 & 0,0 & 0,0 & 0,0 & 0,1 & 2,9 & 0,0 \\
\hline 20 & 2,5 & 3,4 & 1,8 & 1,9 & 0,6 & 0,5 \\
\hline 21 & 6,1 & 3,9 & 2,0 & 2,4 & 2,2 & 0,0 \\
\hline 22 & 0,0 & 0,0 & 1,6 & 0,0 & 2,2 & 1,8 \\
\hline 23 & 4,6 & 5,1 & 2,8 & 2,3 & 0,3 & 0,5 \\
\hline 24 & 0,0 & 3,4 & 0,1 & 1,5 & 1,7 & 1,6 \\
\hline 25 & 5,4 & 3,1 & 1,4 & 1,4 & 4,8 & 0,0 \\
\hline 26 & 4,1 & 5,1 & 0,3 & 1,5 & 1,0 & 0,2 \\
\hline 27 & 0,0 & 0,0 & 0,1 & 0,0 & 1,1 & 1,3 \\
\hline 28 & 7,1 & 3,3 & 1,9 & 0,0 & 1,1 & 0,9 \\
\hline 29 & 8,3 & 6,2 & 2,2 & 0,5 & 0,0 & 2,3 \\
\hline
\end{tabular}


TABELA A2(cont.) - Mensurações cefalométricas individuais, iniciais e finais, para o grupo 2, tratados com extrações de quatro pré-molares.

\begin{tabular}{ccccccc}
\hline \multicolumn{6}{c}{ JOVENS TRATADOS COM EXTRAÇÕES DE QUATRO PRÉ-MOLARES } \\
\hline \multirow{2}{*}{$\mathbf{N}$} & \multicolumn{2}{c}{ Ass. Go } & \multicolumn{2}{c}{ Ass. Ar } & \multicolumn{2}{c}{ Ass. Ra } \\
\cline { 2 - 7 } & INICIAL & FINAL & INICIAL & FINAL & INICIAL & FINAL \\
\hline $\mathbf{1}$ & 3,8 & 1,8 & 2,9 & 2,0 & 1,1 & 0,0 \\
$\mathbf{2}$ & 0,2 & 0,5 & 1,7 & 1,9 & 2,2 & 1,2 \\
$\mathbf{3}$ & 1,2 & 4,8 & 0,0 & 0,0 & 0,0 & 0,1 \\
$\mathbf{4}$ & 3,9 & 4,9 & 1,9 & 4,5 & 1,4 & 2,1 \\
$\mathbf{5}$ & 0,1 & 0,1 & 0,9 & 0,9 & 1,3 & 0,1 \\
$\mathbf{6}$ & 2,3 & 1,7 & 0,0 & 1,5 & 0,0 & 1,9 \\
$\mathbf{7}$ & 5,5 & 0,0 & 2,3 & 0,0 & 0,8 & 1,2 \\
$\mathbf{8}$ & 0,0 & 4,7 & 1,1 & 2,4 & 1,5 & 1,5 \\
$\mathbf{9}$ & 6,5 & 4,3 & 1,4 & 0,0 & 1,9 & 0,0 \\
$\mathbf{1 0}$ & 1,6 & 0,3 & 1,7 & 0,0 & 2,1 & 0,2 \\
$\mathbf{1 1}$ & 0,4 & 1,8 & 1,3 & 0,0 & 1,4 & 0,8 \\
$\mathbf{1 2}$ & 1,0 & 2,8 & 1,7 & 0,0 & 1,1 & 1,4 \\
$\mathbf{1 3}$ & 1,4 & 3,4 & 0,0 & 1,7 & 0,0 & 1,4 \\
$\mathbf{1 4}$ & 2,3 & 4,6 & 1,6 & 1,3 & 0,6 & 1,5 \\
$\mathbf{1 5}$ & 0,0 & 1,6 & 0,0 & 0,0 & 0,7 & 0,9 \\
$\mathbf{1 6}$ & 2,5 & 0,0 & 0,9 & 1,8 & 1,7 & 4,3 \\
$\mathbf{1 7}$ & 4,3 & 5,2 & 1,9 & 3,6 & 1,7 & 1,7 \\
$\mathbf{1 8}$ & 0,0 & 1,0 & 0,0 & 0,9 & 0,0 & 1,2 \\
$\mathbf{1 9}$ & 1,8 & 0,0 & 1,9 & 0,8 & 1,7 & 0,0 \\
$\mathbf{2 0}$ & 1,6 & 2,0 & 0,0 & 0,0 & 0,0 & 0,1 \\
$\mathbf{2 1}$ & 1,5 & 3,9 & 1,4 & 2,3 & 2,6 & 3,9 \\
$\mathbf{2 2}$ & 0,1 & 0,9 & 0,0 & 0,0 & 1,9 & 1,5 \\
$\mathbf{2 3}$ & 0,4 & 0,4 & 0,0 & 1,4 & 0,0 & 0,0 \\
$\mathbf{2 4}$ & 2,2 & 2,8 & 2,6 & 0,0 & 2,4 & 0,0 \\
$\mathbf{2 5}$ & 4,5 & 0,0 & 0,8 & 0,0 & 3,1 & 0,0 \\
$\mathbf{2 6}$ & 1,0 & 1,7 & 0,1 & 0,7 & 0,0 & 1,3 \\
$\mathbf{2 7}$ & 1,6 & 3,1 & 0,0 & 1,9 & 0,1 & 1,9 \\
$\mathbf{2 8}$ & 2,4 & 2,2 & 0,1 & 2,0 & 0,0 & 0,0 \\
$\mathbf{2 9}$ & 6,3 & 5,6 & 0,0 & 3,1 & 2,3 & 1,7 \\
\hline
\end{tabular}

